\title{
A Revision of Syngonium (Araceae)
}

\section{Author(s): Thomas B. Croat}

Source: Annals of the Missouri Botanical Garden, Vol. 68, No. 4 (1981), pp. 565-651

Published by: Missouri Botanical Garden Press

Stable URL: http://www.jstor.org/stable/2398892

Accessed: 21-04-2017 16:22 UTC

JSTOR is a not-for-profit service that helps scholars, researchers, and students discover, use, and build upon a wide range of content in a trusted digital archive. We use information technology and tools to increase productivity and facilitate new forms of scholarship. For more information about JSTOR, please contact support@jstor.org.

Your use of the JSTOR archive indicates your acceptance of the Terms \& Conditions of Use, available at http://about.jstor.org/terms

Missouri Botanical Garden Press is collaborating with JSTOR to digitize, preserve and extend access to Annals of the Missouri Botanical Garden 


\title{
A REVISION OF SYNGONIUM (ARACEAE)
}

\author{
Thomas B. CROAT ${ }^{1,2}$
}

\begin{abstract}
Thirty-three species are recognized for Syngonium in this first published revision since that of Engler and Krause in 1920. Syngonium (now including Porphyrospatha) is the only member of the tribe Syngonieae (Araceae). The genus includes 4 newly described sections, sect. Oblongatum Croat, sect. Cordatum Croat, sect. Pinnatilobum Croat, and sect. Syngonium Croat, defined by leaf morphology, namely by blades basically oblong, cordate, pinnately lobed, and pedately lobed, respectively. Eleven new species are described: $S$. chocoanum (Colombia: Chocó), S. dodsonianum (Ecuador: Los Ríos), S. foreroanum (Colombia: Chocó), S. gentryanum (Peru: Huánuco), $S$. glaucopetiolatum (Costa Rica, Panama), S. harlingianum (Ecuador: Pastaza), S. laterinervium (SW Costa Rica, NW Panama), S. llanoense (Panama), S. sparreorum (Ecuador: Cotopaxi), S. steyermarkii (Guatemala and SE Mexico), S. triphyllum (Honduras to Panama).
\end{abstract}

The genus Syngonium, interpreted here to include the genus Porphyrospatha, is one of two genera of Araceae (the other being Monstera) with a center of diversity in Central America. The following revision of Syngonium includes 33 species of which 11 species are described as new to science. Three species are transferred to Syngonium from other genera, namely Philodendron (2 spp.) and Porphyrospatha (1 sp.).

Although the genus needs more field work, especially in South America, the present revision is the culmination of field work conducted in Central America and northern South America over the past decade.

\section{History of THE Genus}

The first species of Syngonium was described by Linnaeus as Arum auritum in his second edition of Species Plantarum in 1763. Other species of Syngonium were described by early botanical workers in the genera Caladium and Xanthosoma. The latter two genera, both neotropical in distribution, are members of the subfamily Colocasioideae but are now circumscribed as terrestrial, basically acaulescent genera with entire or pedatisect leaves. The genus Arum, in the subfamily Aroideae, as now circumscribed, is restricted to Europe and the Mediterranean region.

The name Syngonium was first used by Schott in 1829. By the time Schott published his Synopsis Aroidearum in 1856 there were 11 described species, the bulk of them having been described in that work. However, of those 11 species I recognize only 1 in this revision, namely, $S$. auritum (most of the species having been synonymized with the widespread $S$. podophyllum). Schott's (1860) Prodromus Systematis Aroidearum dealt with 20 taxa, of which only S. schottianum, $S$. hoffmannii, $S$. wendlandii, $S$. salvadorense, $S$. podophyllum var. peliocladum, $S$. neglectum, and $S$. angustatum are recognized by me. These new species were

\footnotetext{
${ }^{1}$ P. A. Schulze Curator of Botany, Missouri Botanical Garden, Post Office Box 299, St. Louis, Missouri 63166.

${ }^{2}$ This study was sponsored in part by NSF Grant DEB77-14414A01.
}

AnN. Missouri Bot. GaRd. 68: 565-651. 1981.

0026-6493/81/0565-0651/\$08.85/0 
based on collections of H. Wendland, C. Hoffmann, F. M. Liebmann and A. S. Oersted in Mexico and Central America during the 1840s and 1850s.

The last revision of Syngonium was that by Engler \& Krause (1920) published in Das Pflanzenreich. In that treatment two additional species were added (as now recognized) namely $S$. hastifolium and $S$. macrophyllum. The remainder of the species published on or before this revision by Engler have been either placed into synonymy or transferred to other genera.

The most important recent work with Syngonium was that by Birdsey (1955) who completed a detailed morphological review of the Central American and West Indian (in part) species for his doctoral thesis. Although this work was never published, the thorough anatomical studies remain an important contribution. In Birdsey's work a number of new species were described. Two of these species were subsequently described by Bunting (1966) and an additional one, $S$. triphyllum, is described in this paper. Bunting described a total of 6 recognized species during his work in Central America and in Venezuela. A single Syngonium described by $\mathrm{E}$. Matuda is also recognized.

Most of the new species described in this work are relatively rare species collected in the past decade but a few rare species, such as $S$. steyermarkii and $S$. laterinervium, were collected as long as 30 years ago but not recognized.

\section{Generic Relationships}

Syngonium is typical of the subfamily Colocasioideae, whose members have in common articulated laticiferous tubes and leaves almost always having reticulated veins, with the secondary lateral veins joining into a collective vein between the primary lateral veins. In addition, all that have been studied in the field have milky sap.

Schott (1856) in Synopsis Aroidearum classified only the diclinous genera of Araceae. He separated these genera into Efilamentatae and Filamentatae, the latter containing only the genus Stylochiton. Efilamentatae was divided into two parts, Stenozeugmaticae and Pachyzeugmaticae, the latter divided into Gyminogoneae (pistillate flowers lacking staminodia) and Peristatogoneae (pistillate flowers with staminodia). Gyminogoneae was divided into 2 tribes, Caladiinae and Philodendrinae. Caladiinae contained 5 subtribes with genera as follows:

Subtribe Colocasiinae

Ariopsis

Colocasia

Remusatia

Subtribe Alocasinae

Gonatanthus

Alocasia

Subtribe Peltandrinae

Peltandra
Subtribe Syngonieae

Caladium

Xanthosoma

Acontias

Syngonium

Subtribe Problematicae

Anchomanes

Zamioculcas

The subtribes of Caladiinae were later reduced by Schott (1858) as follows:

Subtribe Colocasiinae

Ariopsis

Remusatia
Subtribe Syngonieae

Typhonodorum

Hapaline 


Colocasia
Leucocasia
Gonotanthus
Alocasia
Peltandra

Subtribe Anubiadinae Anubias
Caladium

Xanthosoma

Acontias

Synogonium

Subtribe Problematicae

Zamioculcas

Hutchinson (1932) arranged the family Araceae into 18 tribes and mistakenly over-emphasized the scandent habit of Syngonium in placing it with Philodendron in the subfamily Philodendroideae, which contains neither articulated laticiferous tubes nor milky sap and also lacks the reticulate-veined leaves of the subfamily Colocasioideae.

In the most recent complete revision of the subfamily Colocasioideae by Engler \& Krause (1920) three tribes were included. The two smaller tribes were the Syngonieae with 2 neotropical genera, Syngonium and Porphyrospatha Engler and the Ariopsideae with the single Himalayan genus Ariopsis Nimmo. The third tribe Colocasieae with 5 subtribes contain 12 genera. The subtribe Steudnerinae with 12 species contains the genera Steudnera C. Koch, Remusatia Schott, and Gonotanthus Klotzsch. The subtribe Hapalininae contains only the genus $\mathrm{Ha}$ paline Schott with 5 species, and the subtribe Colocasinae contains only Colocasia Schott with 8 species. These first three subtribes are almost exclusively Asian in distribution. The subtribe Caladiinae with Caladiopsis Engler, Caladium Vent., Aphyllarum S. Moore, Chlorospatha Engler, and Xanthosoma Schott is exclusively neotropical and contains about 65 species. The subtribe Alocasiinae contains 2 genera, Alocasia Schott with 70 species in the Old World and Schizocasia Schott with 4 species in the Philippines, Indochina, and Australia.

The Ariopsideae is distinguished from the Colocasiinae and the Syngonieae by having the synandria of the staminate inflorescence united. The Colocasiinae is distinguished by unilocular ovaries with placentation basal, parietal or subcentral, whereas the Syngonieae has ovaries bilocular (or unilocular by abortion), the ovules being 1 or 2 per locule and anatropous. Syngonieae is also the only tribe in the subfamily with scandent plants.

Because of their neotropical distribution and similarly veined leaves, as well as the frequent presence of milky sap, certain members of the Caladiinae, namely Caladium and Xanthosoma, have been confused with Syngonium. Caladiinae is terrestrial, either acaulescent with subterranean stems or caulescent with short, usually erect stems, whereas Syngonium is always epiphytic, frequently with scandent stems.

\section{The Genus Porphyrospatha}

Engler (1879) distinguished Porphyrospatha from Syngonium because the fruits of Porphyrospatha supposedly were free from one another at maturity, whereas in Syngonium the fruits formed a syncarp. I now believe that this distinction was based on a misinterpretation of poorly preserved material. Porphyrospatha was based on Syngonium schottianum from Costa Rica, which has the typical syncarp of Syngonium. It is possible that Engler's interpretation of a genus with free fruits was based on an old fruiting inflorescence. These may 
appear segmented, especially after drying, and it is doubtful that Engler ever saw fresh fruits of his proposed genus. Old syncarps have been observed which were partly eaten, perhaps pecked apart by birds, and such an inflorescence upon drying might well have the appearance of having distinct fruits. [See for example Croat 25542 (MO).] Unfortunately, it is not possible to restudy the material seen by Engler, since the only material apparently seen by him was a collection of Wendland from Costa Rica, which is no longer extant. The illustration of this species in Berlin shows an inflorescence in an intermediate stage of development and certainly not in mature fruiting stage.

\section{MORPHOLOGY}

STEM

Syngonium is characterized by polyphyllous sympodial growth with an elongate shoot and no branches. After the shoot terminates in an inflorescence or a series of inflorescences, a single branch arises from the lateral bud, two nodes back from the apex (Madison, 1978). The stem branching pattern as reported by Engler (1877) is as follows:

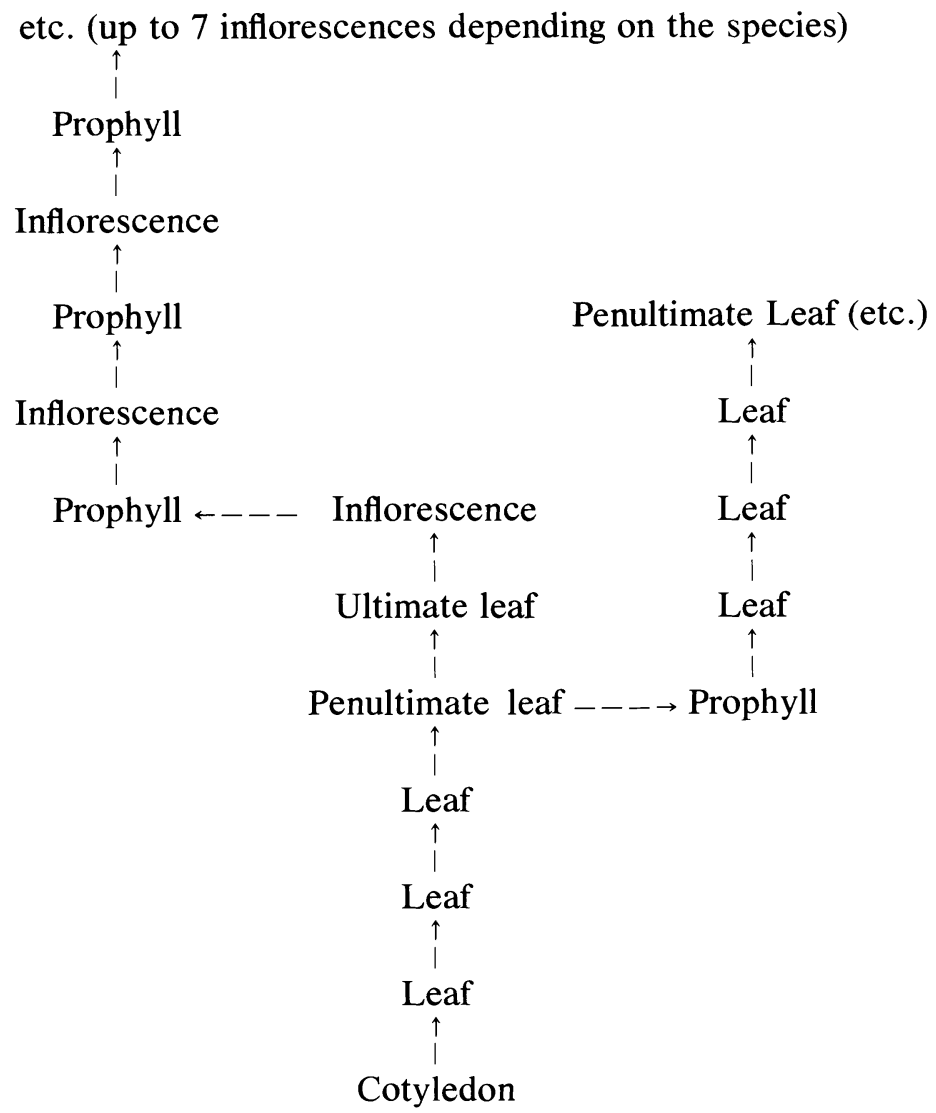

The pattern depicted here is indefinitely repeatable, limited only by change in the ecological conditions that allow flowering. (See also section on GrowTH HABITs.) 
Stems may initially be only a few mm diameter in juvenile plants but up to 6 $\mathrm{cm}$ diameter in adult plants. Syngonium stems probably average 1 to $2 \mathrm{~cm}$ diameter. Stems are invariably green and presumably photosynthetic in juvenile plants, but the epidermis soon loses its color on adult plants (usually within 1 node below the inflorescence). The possibility of having photosynthetic tissue in the creeping phase of growth where internodes are elongate and leaves are small (see section on GROWTH HABITs) would be important ecologically.

In general the stems of Syngonium are unbranched though branching sometimes occurs, especially if the stem has been injured. Generally, climbing stems have elongated internodes. The internodes are often appreciably shorter on flowering portions than elsewhere. Some species, especially those species with thicker stems, such as $S$. macrophyllum, $S$. crassifolium, $S$. schottianum and $S$. sagittatum, may have the internodes quite short on flowering segments.

Stem segments are terete or more commonly oval in cross-section and have a shallow groove on one side above the axillary bud. This generally is diminished or absent distally. Birdsey (1955) reports a multiseriate epidermis in Syngonium with the developing stem near the apical meristem having only a single layer of cells and sections distal to the apical meristem having 3 or more layers of epidermal cells. Part of these layers may be suberized but at least the innermost is not suberized. Birdsey (1955) reports that it is not yet known whether this multilayered tissue arises from the epidermis or underlying collenchyma cells.

Stems are to some extent flexible but, if bent, the outer epidermis often cracks free. Even in undisturbed plants, the outer epidermis often becomes cracked and peels. In such cases the outer epidermis is generally brown or yellowish with the underlying epidermal cells green or olive green. The color of the epidermis is sufficiently variable to provide useful specific characteristics. For example, the outer epidermis of $S$. erythrophyllum always dries a characteristic brown only a short distance from the stem apex. Drying plant collections invariably causes shrinkage of the stem with the result that herbarium specimens have the outer epidermis cracked or fissured and often peeled free from the stem.

In the case of $S$. angustatum the epidermal cells are pushed out by underlying cells to provide rough spots visible to the naked eye (Birdsey, 1955), while the excrescences of $S$. podophyllum var. peliocladum are very large, providing the chief taxonomic characters for its separation from $S$. podophyllum var. podophyllum.

Another useful taxonomic character involving the stem is the presence or absence of a waxy layer, although the character does not necessarily maintain itself throughout the range of a species. For example, the stems of $S$. podophyllum in Mexico are glaucous and are useful there in separating it from $S$. angustatum, but in Panama and in South America the stems are never reported to be glaucous.

The glaucous condition is also present on other parts, especially the peduncle and the fruits, e.g., in $S$. chiapense and $S$. macrophyllum. The glaucous peduncles of $S$. angustatum are useful in separating it from $S$. podophyllum.

Stem anatomy was dealt with briefly by Van Tieghem (1867) and will be dealt with more completely in work underway by R. Keating of Southern Illinois University, Edwardsville. Birdsey (1955) also presents a thorough survey of stem anatomy. 
Stem cross-sections of Syngonium show a well-defined layer of collenchyma (cortex) beneath the epidermal layers with a poorly defined boundary lacking between the cortex and the central vasculated region of the axis (Birdsey, 1955). Starch grains are randomly distributed throughout the parenchyma of both the central cylinder and the cortex, and idioblasts containing raphides as well as cells containing druses are present, though in lower frequency than in the petioles (Birdsey, 1955). The stem of Syngonium lacks a well-defined pith and has the scattered vascular bundles characteristic of monocots. Always present in the stems of Syngonium are articulated laticiferous cells, i.e., secretory cells, which are placed end-to-end, forming a continuous tube with numerous branches and anastomoses (Birdsey, 1955). The contents of the cells are rich in tannins as well as latex (Solereder \& Meyer, 1928).

\section{ROOTS}

Adventitious roots of two types emerge just below each node of the stem. In addition to a number of skototropic clasping roots, whose main function is that of holding the plant to its support, there is a single feeding root that is positively geotropic and diverges from the stem at an angle that puts it into a position to absorb nutrients some distance from the plant (Birdsey, 1955). The anatomy of these roots differ at least quantitatively (Birdsey, 1955), with the feeding root having greater overall diameter, a proportionally larger central cylinder, and proportionally larger vessels.

\section{LEAVES}

Syngonium phyllotaxy is reported as $2 / 5$ divergence (Engler, 1877), though the arrangement may be obscured by the slight twisting of the petioles (Birdsey, 1955).

The petiole of Syngonium is always conspicuously sheathed from about the middle to near the apex, generally between the middle and the upper $4 / 5$ of the petiole. The sheath functions in protecting the newly emergent leaves and the inflorescences. The sheath is generally very broad, especially at the base, and the two sides are generally quite unequal in height. The apical portion of the sheath is often free-ending, and the free part varies from acute to rounded or emarginate at the apex. The petiole of section Oblongatum differs in being proportionately broader and extends often beyond the base of the blade.

The petioles have a uniseriate epidermis, with numerous intercellular spaces (Birdsey, 1955). The vascular bundles are irregularly scattered throughout the fundamental tissues. Perhaps owing to the numerous intercellular lacunae, the petioles of Syngonium are soft and can be easily crushed in comparison to other aroid genera such as Anthurium. The cross-sectional shape of the free portion of the petiole beneath the blade often has taxonomic significance. Although all are characterized by being rounded on the abaxial side and most have a single more or less conspicuous adaxial rib, the rib varies from being almost absent in the case of $S$. chiapense, $S$. neglectum, and $S$. auritum to quite noticeable in $S$. podophyllum var. peliocladum, S. macrophyllum, and S. salvadorense, to noticeably acute in $S$. angustatum, $S$. triphyllum, $S$. wendlandii, and $S$. hoffmannii. 
In some species the lateral adaxial margin of the petiole is also ribbed. This is apparent in $S$. hoffmannii and $S$. wendlandii but especially in $S$. triphyllum.

The petioles of juvenile leaves often differ remarkably from that of the adult and have a greater tendency to be canaliculate rather than 1-ribbed as in the adult leaves.

The leaf blade morphology of Syngonium, as in many other genera of Araceae, is quite variable. Species often begin flowering before the full course of maturation takes place in leaf development. For example, young adult plants may have fewer leaflets per leaf than older plants. This has created a situation where species have been described as new because the adult leaves were unlike plants which had previously been described.

The leaves easily fall into four basic types, and it is along these lines that the sectional classification of the genus is arranged.

Section Syngonium.-By far the most common leaf type in the genus is that of section Syngonium with trisect or pedatisect adult leaf blades. Leaf blades range from the strictly trisect blades of $S$. gentryanum to the more highly divided blades of $S$. podophyllum, which vary from trisect to 11-pedatisect. Though the condition is not necessarily a strict matter of maturity, older, more mature plants in any population tend to be more highly divided. Any individual may have considerable variation in the degree of lobing of the leaf depending on where the leaf occurs on the stem. The higher up the stem, generally, the more highly lobed or segmented the leaf becomes. As mentioned in the section on STEMS, the seedling leaves of all species are entire. Generally the seedling leaves are ovate or elliptic, and frequently they are also weakly lobed at the base. The intermediate climbing leaves are always more conspicuously lobed at the base. The leaves of such intermediate, pre-adult climbing forms are generally conspicuously hastate or sagittate. It is during this pre-adult climbing stage that species are most difficult to distinguish from one another, since nearly all the species in section Syngonium have leaves that are remarkably similar. However, even at this stage, differences between species begin to emerge. Some species, such as $S$. triphyllum, have posterior lobes that are narrow and are directed almost perpendicular to the median lobe. The abruptness of change between an entire leaf with prominent basal lobes and a 3-lobed leaf varies considerably from species to species. In some species all intermediate stages are easily found, whereas in other species the plant seems to switch from an entire pre-adult leaf to a 3-lobed or 3-parted pre-adult leaf very quickly with no evidence of intermediate leaf forms. The general pattern of change extend from a more or less sagittate blade, to a hastate blade, to a 3-lobed blade with the posterior lobes very constricted near the base. The development proceeds to where the posterior lobes become lateral leaflets, i.e., they become completely free of the median lobe.

The lateral segments or leaflets are invariably inequilateral and in most cases the outer half of the segment or lobe is much wider and conspicuously auriculate at the base. The degree to which the auricle develops is very variable from plant to plant, even in the same species (particularly true of species like $S$. podophyllum), but it is often sufficiently consistent in a species to be of taxonomic value.

Leaf development of five or more pedatisect leaves invariably proceeds with the pinching off of an auricle to produce another segment or leaflet which in turn 
goes through the same process to produce still another pair of segments or leaflets.

The degree of separation of the segments or leaflets is an additional taxonomic character in some species (and not in others). Some species consistently have leaflets free from one another with exposed sections of the rachis dividing the leaflets. In morphologically variable species, such as $S$. podophyllum, the degree of separation of the leaflets is highly variable, even at the populational level with leaves varying from those with united segments to those with distinct leaflets.

Section Cordatum.- In this section the leaves are entire with generally conspicuously developed posterior lobes. The overall leaf shape may be ovate or oblong-ovate or rarely hastate, and the anterior lobe is sometimes weakly constricted near its base. The section is the second most common and includes those species (among others) that Engler placed in his genus Porphyrospatha. Seedling leaves are similar to those of section Syngonium and soon become ovate-elliptic with small posterior lobes, but instead of becoming more 3-lobed, they begin to assume the shape of the adult blade and merely get larger. In section Cordatum there are no leaves with distinctly intermediate phases, which are so variable and interesting in section Syngonium.

Section Oblongatum.-The species in section Oblongatum differ markedly from all others in the genus because of the oblong to oblong-elliptic to ovateelliptic leaf blades and petioles, which are broadly sheathed to the apex with the emarginate free portion of the sheath often extending beyond the base of the blade. In this section the juvenile leaves are almost identical to the adult leaves, differing only in being much smaller. Intermediate stages are much like the adult blade.

Section Pinnatilobum.-This section is represented by $S$. steyermarkii, the only incised-lobate species in the genus. Juvenile leaves are ovate, soon becoming subcordate at the base and developing sinuate margins laterally. As the blade matures, it becomes increasingly more deeply lobed and more conspicuously lobed at the base until it assumes its adult form, which looks vaguely like the common Philodendron radiatum Schott with incised-lobate leaves.

Leaf blade venation of Syngonium easily characterizes it as a member of the Colocasioideae. The venation type is the brochidodromous type (Dilcher, 1974), and the primary lateral veins (i.e., secondary, see Croat \& Bunting, 1979), after extending laterally from the midrib toward the margin, join into a collective vein which extends to the apex roughly parallel to the margin. In Syngonium there are always 3-5 separate collective veins. The primary (inner) one, being the largest, is initiated by one of the lowermost primary lateral veins. Successively smaller collective veins, located at smaller distances from the blade margin, arise from progressively lower primary lateral veins or even weak secondary veins branching off the midrib. Frequently the 4 th and especially the 5 th collective vein are so near the margin that they cannot be seen with the naked eye.

The origin of the primary lateral veins is usually acute near the base, often becoming more obtuse toward the apex and rarely arising at nearly right angles to the midrib.

One of the characteristics of Syngonium and other members of the Coloca- 
sioideae is the presence of conspicuous reticulate venation. Tertiary veins can arise from the primary lateral veins (i.e., secondaries) in which case they orient toward the margin and become parallel to the primary lateral veins, or they can arise directly from the midrib. The tertiary veins merge distally and give rise to quaternary veins. The quaternary veins are found irregularly between the tertiary veins and at oblique angles, randomly oriented. The quaternaries in turn give rise to the lowest order of veins, namely the quinary veins which form the areoles. The areoles are 3-, 4- or 5-sided and lack a free-ending veinlet. Both the 4th and 5 th order veins are restricted to the adaxial plane of the blade (Birdsey, 1955). An unusual feature of the quaternary veins of Syngonium and other Araceae such as Xanthosoma is that they may cross over a series of tertiary veins before joining with another vein (Birdsey, 1955).

Laticiferous cells are often very prominent in the leaf tissue, with two series of laticiferous cells paralleling each vein, sometimes even up to the 5 th order of veins (Birdsey, 1955).

\section{REPRODUCTIVE STRUCTURES}

The inflorescences of Syngonium, though always terminal, appear to be axillary because after the inflorescences are produced, the continuation shoot, which arises from the penultimate leaf, displaces the inflorescence to the side and overtops the inflorescences. Inflorescences may be solitary or several but are interspersed with bicarinate bracts called prophylls. A number of species, such as $S$. angustatum, $S$. podophyllum, and $S$. macrophyllum, produce between 6 and 11 inflorescences, whereas many species produce only 2 inflorescences, and some may produce a solitary inflorescence. The number of inflorescences that persist and produce mature fruits is frequently fewer than those that reach anthesis. Some are perhaps not pollinated or are removed before maturity for some reason.

Inflorescences are nearly always erect and the peduncles are generally obtusely 3-sided or subterete with an obtuse rib on one side. The peduncle, often relatively short at anthesis, generally elongates substantially in fruit and becomes recurved, no doubt due to the heavy weight of the fruits.

The unopened spathe is convolute and very tightly closed over the spadix, generally exceeding the spadix by $1 / 6-1 / 3$ its length. The spathe is often conspicuously constricted about midway, separating the spathe tube from the spathe blade. At flowering time the spathe unfurls and generally forms a more or less hemispherical cup behind the spadix. By the time the spathe is fully open, it is generally white or creamy white, at least on the inner surface of the spathe blade, though the blade and more frequently the inner surface of the spathe tube may be colored or at least tinged with red or violet. In some cases, such as $S$. neglectum, the spathe may be reflexed backward, which more fully exposes the spadix. Though the lower convolute part of the spathe (the tube) is rarely fully opened, it opens far enough to give easy access to the pistillate flowers for pollinators. The spathe remains open for 2-3 days and then recloses over the spadix. The blade portion of the spathe then soon withers and often promptly falls free. In other cases the old dried spathe blade persists until later stages of fruit de- 
velopment. The spadix is divided into three sections. Staminate flowers occupy most of the apical $4 / 5$ or more of the spadix. The lowermost section is occupied by the pistillate flowers. The basal part of the staminate spadix is made up of sterile staminate flowers, and these may form a distinct segment, or it merges imperceptibly with the staminate flowers. Flowers are arranged in a series of close spirals.

The pistillate part of the spadix is generally much narrower than the staminate part and is generally greenish, though sometimes pale orange. Length varies from 7-48 $\mathrm{mm}$.

Each pistillate flower consists of two fused carpels (rarely three). The flowers are in turn fused into a single unit that later matures into a syncarp. Each locule usually has one ovule but may rarely have two (Birdsey, 1955). Ovules are anatropous and placentation is basal.

Birdsey (1955) describes four stigma types: (1) discoid, characteristic of $S$. angustatum, S. auritum, S. chiapense, S. macrophyllum, and S. podophyllum; (2) bilabiate (2-lobed or fused together in a ring), characteristic of $S$. hoffmannii and $S$. salvadorense; (3) orbicular, restricted to $S$. wendlandii; and (4) cupulate, restricted to $S$. triphyllum.

Sterile staminate flowers are usually roughly the same size as the fertile staminate flowers but more irregular in shape and generally more widely spaced. Sometimes the irregularity in shape results from a fusion of two flowers.

Fertile staminate flowers of Syngonium are made up of usually 4 (rarely 2, 3 or 5), nearly sessile anthers. The anthers are fused to varying degrees into a synandrium. The latter is truncate at the apex and sometimes depressed medially. The margins of the synandrium are rhombic, pentagonal, hexagonal, or irregular in outline. Sometimes the margin is also crenulate. Birdsey (1955) divided pollen grains into three distinct types: (1) spiny, characteristic of $S$. angustatum, $S$. auritum, $S$. chiapense, $S$. macrophyllum, and $S$. podophyllum; (2) smooth, characteristic of $S$. hoffmannii, $S$. neglectum, S. salvadorense, and $S$. wendlandii; and (3) knobby, characteristic of only $S$. triphyllum.

\section{Cytology}

Chromosomal studies with the Araceae have been fairly extensive for a tropical family, perhaps owing to the fact that the family is so widely cultivated. The most extensive reviews of chromosomal variation in the family are those by Marchant (1970, 1971a, 1971b, 1972). Somatic chromosome counts range from $2 n=22$ to $2 n=140$ for the family, and there is considerable diversity in the size of chromosomes. Jones (1957) indicates that $x=6$ and 7 are the basic numbers for the family and that others have been derived. Larsen (1969) and Hotta (1971) believe that the most common base number is $x=7$, followed by $x=13$. Jones (1957) suggests that $2 n=26,30$, and 34 are amphidiploid numbers that arose from hybridization and doubling of diploid species. Polyploidy appears to have played an important role in the evolution and speciation of the family.

Marchant (1970) reported base numbers of $n=7$ for those members of the Colocasioideae which he investigated, namely Remusatia, Alocasia, Colocasia, Xanthosoma, Caladium, and Ariopsis. Syngonium has had counts of $2 n=24$ (Pfitzer, 1957; Marchant, 1970), $2 n=26$ (Marchant, 1970), $2 n=28$ (Sharma, 1970), and $2 n=30$ (Marchant, 1970). 


\section{PHENOLOGY}

Phenological behavior of flowering and fruiting in Syngonium is poorly understood because no long-term observations have been made. From an analysis of herbarium material (now very abundant for some species) it can be stated that some species (perhaps most) flower over a relatively long period of time each year. Notwithstanding the fact that irregular collecting patterns could contribute to the results, it appears that some species are to some extent seasonal in their flowering behavior. For example, $S$. angustatum and $S$. macrophyllum show greatest flowering in the first part of the rainy season (beginning about May) in Central America, with some flowering during the dry season, but no flowering in the latter part of the rainy season.

Some species appear to be bimodal in their flowering behavior with tendencies to flower in the beginning of the dry season and the rainy season.

\section{Pollination}

Though no pollinators have been reported in the literature for Syngonium species, there seems to be little doubt that the genus has the same type of pollination syndrome already known for Philodendron, Dieffenbachia (Croat, 1978), and Xanthosoma, which are known to be pollinated by large awkward scarab beetles of the subfamilies Rutelinae and Dynastiniae. T. Ray (pers. comm.) reports that $S$. triphyllum is pollinated by the genus Cyclocephala (Dynastiniae) in Costa Rica. In such cases the behavior of the spathe and spadix are important and in all probability Syngonium is thermogenetic in the same way as Philodendron (Sheridan, 1960), Monstera (Sheridan, 1960; Madison, 1977), Symplocarpus, Arum, Arisaemum, Amorphophallus, Biarum and Sauromatum (James \& Beevers, 1950; Smith \& Meeuse, 1966; Knutson, 1972). In these cases it has been shown that temperature increase in the spadix is due to rapid oxidation of starch (James \& Beevers, 1950; Beevers, 1950; Hatch \& Millard, 1957; Hess \& Meeuse, 1968a, 1968b; Knutson, 1974; Nagy et al., 1972).

Flowers of Syngonium are markedly protogynous, becoming receptive 1-2 days before the staminate flowers shed pollen. They are already receptive by the time the spathe opens. At this stage the spathe is broadly opened and access to the pistillate flowers is easy. Presumably pollinators enter the spathe at this time and visit the pistillate flowers while the staminate flowers are not yet open. Usually, by the beginning of the second day the pollen has begun to emerge in stringy masses from between the synandria, and the pistillate flowers are no longer receptive. By this time the spathe tube is much contracted and nearly closed, perhaps forcing an entrapped beetle to crawl over the pollen-covered spadix, as in the case of Dieffenbachia (Croat, 1978).

\section{INFRUCTESCENCE}

After pollination, the spathe tube becomes tightly reclosed and rots off, taking with it the remaining staminate flowers. Generally the dehiscence of the spathe tube follows a smooth line of thickened, often raised tissue, which is not readily apparent when the spathe first opens but which may become conspicuous by the time the spathe is closing. Part of the staminate spadix, generally including all of the sterile staminate flowers, is closed into the spathe tube. This material even- 
tually rots but remains within the spathe tube. As in the case of Alocasia pubera (van der Pijl, 1933), the staminate flowers of Syngonium may be good places for insects to oviposit since part of the staminate spadix remains enclosed in the spathe tube and would provide an ideal hatching ground for larvae.

At maturity of the syncarpous fruit, the spathe tube is usually colored on the exterior, even though it is usually green at the time of flowering. The spathe tube usually also opens to expose the syncarp. The syncarp is generally pale, with brown flecks representing the original epidermal tissue. Sometimes the spathe tube breaks up and turns inside out, with its bright, colorful interior exposed against the white syncarp, e.g., S. triphyllum. Birdsey (1955) reported that only two species, namely $S$. wendlandii and $S$. mauroanum, had syncarps that matured white, but I found this to be true also for $S$. triphyllum. In such cases the fruits might be adapted for bird dispersal, since they would be highly visible and could be pecked open by birds. In most cases, however, the fruits seem better suited for mammal dispersal (presumably monkeys) because they are not very colorful, yet they are fragrant.

Each fruit of Syngonium contains 50-100 or more seeds. These are generally somewhat ovoid or cylindroid, usually 5-10 $\mathrm{mm}$ long and 3-6 $\mathrm{mm}$ in diameter, with both ends rounded. The pericarp is usually brown or black with the whole interior white and moderately soft. Germination of the fruits is prompt and viability of the seed is lost promptly if they are allowed to dry out.

\section{GROWTH Habits}

A detailed study of growth behavior has been carried out on several species in Costa Rica by T. Ray (Harvard University). Only the general aspects of growth behavior will be reported here. Juvenile plants of a species of Syngonium are often extremely abundant, but there seems to be no correlation between the abundance of seedlings and the abundance of adults. In some cases adults are frequent and in other cases they are rare.

After germination of the seed, which is always in the soil, the plant remains in a rosette stage for a considerable time, the stem being slender with very short internodes. Leaves, at first ovate, are soon at least weakly lobed at the base. (A discussion of leaf development has already been made under the section on leaves.) Later (at least in some species), the stem elongates rapidly and growth is skototropic (Strong \& Ray, 1975), i.e., the stem grows toward the darkest area available. Stem diameter may initially be only a few millimeters in this creeping phase, but internodes are elongate and leaves are much reduced. After the stem reaches a tree, it switches its physiology dramatically and begins to grow up the trunk toward the light. The stem continues up the trunk with relatively elongate internodes but also grows in girth and produces larger leaves. At this stage, the leaves (depending on the section) take on a different form. For example, climbing leaves of section Syngonium become sagittate or hastate. As the stem climbs, it becomes larger in girth and produces larger leaves and often stems with shorter internodes. Ultimately the plant produces adult foliage, which, depending on the species, can continue to be modified as the plant gets older or bigger. For example, pedatisect species tend to add more leaflets as they get larger.

All species of Syngonium are climbers and generally hemiepiphytic, though 
plants may survive with all apparent connections to the ground severed. Older plants particularly have good development of an adventitious root system, which can trap both water and nutrients.

Though it has fewer growth forms than Monstera, described by Madison (1977), the genus Syngonium has a wide range of variation in growth form. In general, the larger the stem of the adult plant, the shorter will be its internodes at time of flowering. The stem diameter of all species ranges from $1.7 \mathrm{~cm}$ at the smallest extreme to $2.3 \mathrm{~cm}$ at the largest extreme. Species with very slender stems tend to occupy disturbed habitats such as fence rows, and they tend to flower readily and frequently but generally produce fewer than 3 inflorescences. For example, species with stem diameters averaging about $1.5 \mathrm{~cm}$ in diameter produce an average of 3 inflorescences per axil, whereas species with stem diameters averaging $3.8 \mathrm{~cm}$ have an average of 4.8 inflorescences per axil. There are notable exceptions, such as $S$. angustatum with stem diameters of up to only $1.5 \mathrm{~cm}$ but with usually up to 7 inflorescences per axil. At the other extreme are such species as $S$. occidentale with stem diameters to $3 \mathrm{~cm}$ but only a solitary inflorescence per axil, and $S$. sagittatum with stem diameters to $4 \mathrm{~cm}$ and up to 3 inflorescences.

Internode length at flowering time is often very great, sometimes exceeding $12 \mathrm{~cm}$. Some species such as $S$. laterinervium tend to branch readily and festoon the plant upon which they are growing. Species with stout stems, such as $S$. schottianum and $S$. macrophyllum, are frequent only in large trees and tend to flower less frequently but generally produce more inflorescences. Adults of such species are generally rarer, perhaps being capable of maturing only in trees of certain height. Certainly, such species are never capable of reaching maturity on or near the ground.

Most species of Syngonium have medium-sized stems and though their internodes are somewhat shortened at flowering time, they continue to elongate rapidly so that a considerable distance exists between a mature infructescence and a new inflorescence.

The genus Syngonium goes through modifications in its growth much like those in Monstera (Madison, 1977). Most species rarely branch except when a plant is damaged or when it outgrows its support and begins to fall. When the stem of an adult plant begins to droop from its support, it changes its growth habits to produce narrower, longer internodes and smaller leaves. This, of course, allows the plant to put more of its growth into elongation in order to more quickly reach a new source of support. Once the new support has been found by creeping across the forest floor, the stem begins to climb once more and again modifies its growth to produce a succession of intermediate pre-adult leaves and adult leaves. The pattern can be repeated endlessly.

\section{GEOGRAPHY}

The center of diversity for Syngonium is in Costa Rica and Panama, which together have a total of 16 species. Costa Rica has 13 species while Panama has 11 species. Mexico is a secondary center of diversity with 8 species. Middle America (Guatemala to Costa Rica) has 8 species and the West Indies proper have but a single species (with another in Trinidad). 
The most common and widespread species is $S$. podophyllum which ranges from Mexico to Brazil. Except for $S$. macrophyllum, most of the remainder are much less wide ranging and many, such as $S$. glaucopetiolatum, $S$. gentryanum, $S$. hastifolium, S. laterinervium, S. llanoense, S. occidentale, S. podophyllum var. peliocladum, $S$. sagittatum, $S$. sparreorum, and $S$. steyermarkii, are believed to be geographically isolated. Some, such as $S$. mauroanum, occupy special, restricted life zones while others such as $S$. podophyllum and $S$. hoffmannii occupy a wide variety of ecological habitats.

There are relatively few species of Syngonium in South America, though admittedly South America has been less well explored. In addition to the widespread $S$. podophyllum, which occurs in all parts of tropical South America, there is only one other species, $S$. macrophyllum, which ranges into South America from Central America. There are 11 species that are endemic to South America.

It is possible that Syngonium was a component of the remnant Paleogene tropical North American flora, as was suggested by Madison (1977) for the genus Monstera. Representatives of all sections of Syngonium are present in Central America, whereas only the two more common sections Syngonium and Cordatum are represented in South America. In addition, both of these sections are much better represented in Central America.

The distribution of Syngonium species does not show any of the disjunct distributional patterns for Central America that are exhibited by Monstera (Madison, 1977). Except for the three species of Syngonium already mentioned, which range from Mexico to Costa Rica or beyond (i.e., S. angustatum, S. macrophyllum and $S$. podophyllum), all other species in Central America are restricted either to Mexico or to Costa Rica and Panama.

Indicating that the paucity of Syngonium species in parts of Central America may be due to undercollecting is the fact that W. D. Stevens, now working on the Flora of Nicaragua, has already added S. schottianum to the flora of Nicaragua. It was previously thought to be restricted to Costa Rica and Panama.

The suggestion that Mexican species have long been isolated from those of Costa Rica and Panama is supported by the fact that only 3 Mexican species reach Panama, these being $S$. angustatum and the two widespread species $S$. podophyllum and $S$. macrophyllum, which range to South America.

Evidence that there may have been a long separation of populations of Mexican and Costa Rican or Panamanian species can be seen in the morphological variation among Mexican and Costa Rican populations of the two most widespread species in Central America. Both $S$. podophyllum and $S$. macrophyllum populations in Costa Rica and Panama differ in many ways from those in Mexico. These differences are discussed in the commentary following each species.

\section{INFRAGENERIC CLASSIFICATION}

No previous worker has presented a sectional classification for Syngonium. This may be because until recently, two of the four sections I am proposing had not yet been discovered. Syngonium crassifolium and S. schottianum have both juvenile and adult leaves distinctly different from any species Engler \& Krause (1920) included in their revision of Syngonium, but these two species were placed in a distinct genus (albeit presumably based on other characters, see section 
discussing the genus Porphyrospatha). Nevertheless, Engler and Krause did include in their revision two species with adult leaves that were not the typical trisect or pedatisect leaves of section Syngonium. These were S. hastifolium, which in every other respect is like a juvenile plant of $S$. podophyllum, and $S$. reticulatum, now known to be a species of Xanthosoma.

Apparently the juvenile phases, which help to understand sectional differences, were not available to Engler. Nevertheless, the sectional classification I am creating is most readily recognized in the adult foliage, although there are corollary differences in the juvenile and pre-adult phases of growth.

I divide Syngonium into four sections based on the shape of the adult lamina.

Section Syngonium: Leaves trisect or 5-11-pedatisect. This section is by far the largest and most variable. It is also the only section with any truly widespread species. The species exhibit marked heteroblastic development, with changes in leaf development in the juvenile, creeping, climbing, and adult phases. These are described in detail under the heading LEAVES.

Section Cordatum: Leaves entire and with conspicuous posterior lobes. This section is the second largest section in the genus. Some of its species are relatively widespread. All (except perhaps $S$. hastifolium) are thick-stemmed, slow-growing hemiepiphytes that have juvenile leaves similar to the adult forms, only smaller.

The section is represented by five species, three of which are restricted to Central America. Juvenile leaf phases are ovate-cordate and intermediate stages begin to approach the adult shape with no major modifications. One species in section Cordatum, S. chiapense, occasionally has broad, rounded lobes separated somewhat from the posterior lobes. This tendency to produce auricles at the outer edge of the posterior lobes is characteristic of section Syngonium and reflects the relationships of these two sections. Nevertheless, S. chiapense has the entire, ovate-cordate leaf blades characteristic of section Cordatum.

Section Oblongatum: Leaves entire, elongate, the petiole broadly winged to the apex. This section differs not only in the shape of its leaves but in having a petiole that is broadly sheathed its full length with a free-ending ligule extending generally beyond the base of the blade. Juvenile leaves differ little from the adult except in size. The section is represented by two species, $S$. llanoense from the Isthmian region of Panama and $S$. armigerum from Costa Rica.

Section Pinnatilobum: Leaves deeply incised-lobate; petiole sheathed to about the middle; juvenile leaf blades entire, more or less ovate, cordate at the base; intermediate leaves increasingly incised. The section is represented by a single species, S. steyermarkii, from Mexico and Guatemala.

\section{TAXONOMIC TREATMENT}

Syngonium Schott, Wiener Z. Kunst 3:780. 1829. TYPE: Arum auritum L. = Syngonium auritum (L.) Schott.

Porphyrospatha Engler in A. DC., Monogr. Phan. 2:289. 1879. TYPE: Syngonium schottianum Wendl.

Epiphytes or hemiepiphytes; sap of most parts milky; stems scandent or shortcreeping, usually unbranched, the internodes long or short, the nodes usually rooting heavily; juvenile plants usually terrestrial, the first blades ovate to elliptic, simple, with succeeding stages usually sagittate and climbing; adult leaves simple 
or variously divided, trisect to pedatisect with 5-11 leaflets, rarely incised-lobate; petioles sheathed in part, rarely throughout their length, the upper part subterete, usually with an obtuse medial rib; simple blades usually ovate, sometimes oblongelliptic, frequently \pm sagittate; blades usually moderately thin, the median segments usually more or less equilateral, the lateral segments of trisect or pedatisect blades often conspicuously inequilateral and auriculate; primary lateral veins spreading, forming up to 3 or more collective veins.

Inflorescences 1 or more per axil; peduncles erect in flower, pendent in fruit, commonly rounded on one side, obtusely angular on the other side; spathe tube ovoid to ellipsoid, green at anthesis, frequently tinged with purple, often red, orange or yellow in fruit, usually reopening to expose the syncarp, sometimes brightly colored within at maturity; spathe blade white to greenish white and opening broadly at anthesis, usually ovate-elliptic, often acuminate at the apex, normally much constricted at the base, always drying soon after anthesis, usually deciduous; spadix much shorter than the spathe, the basal pistillate part cylindrical to truncate-conical, green to orange, the apical staminate part longer than the pistillate part, clavate, white, with larger, more irregular, sterile flowers at the base, the sterile staminate part usually \pm swollen and wider than the pistillate part; flowers unisexual, naked; staminate flowers consisting of 3 or 4 stamens united into a synandrium, the synandria truncate to somewhat rounded at apex, the connective of the anthers thick, dehiscent below the apex of the connective by a short slit, rounded or obtuse at the base; pistillate flowers connate, the ovary obovoid or oblong-obovoid, normally 2-celled (rarely 3- or 1-celled); ovules 1 (rarely 2) per cell, erect, anatropous; stigmas usually discoid or bilabiate, rarely orbicular or cup-shaped; fruits baccate, connate into an ovoid syncarp, this usually brown, sometimes white at maturity; seeds obovoid or ovoid; funicle short; testa smooth, thin, black or dark brown, shiny; endosperm lacking.

\section{KEy TO THE SECTIONS OF SYNGONIUM}

1a. Leaf blades of adult plants simple; leaf blades of juvenile and the pre-adult climbing phases not markedly different from those of the adult.

2a. Leaf blades lacking posterior lobes or the blades merely subcordate.

Section Oblongatum (Species 1-3)

2b. Leaf blades with large, well-developed posterior lobes, the blades ovate, oblong-ovate or hastate.

Section Cordatum (Species 4-13)

1b. Leaf blades of adult plants markedly divided, trisect, 5-11-palmatisect or incised-lobate; leaf blades of juvenile and pre-adult climbing phases markedly different from those of the adult.

3a. Leaf blades of adult plants incised-lobate (the anterior lobe pinnately lobed); leaf shape of pre-adult climbing phase usually not simple, usually variously lobed but not as deeply lobed as the adult. Section Pinnatilobum (Species 14)

3b. Leaf blades of adult plants trisect or 5-11-pedatisect; leaf shape of pre-adult climbing phase simple, usually hastate or sagittate. Section Syngonium (Species 15-33)

\section{Key to The SPEcies of S YNGONIUM}

1a. Leaf blades not divided into segments.

2a. Leaf blades oblong-elliptic or ovate-elliptic, merely rounded to subcordate at the base; petioles sheathed nearly their entire length.

3a. Blades mostly less than $15 \mathrm{~cm}$ long; primary lateral veins arising from the lower half of the blade.

3b. Blades commonly more than $15 \mathrm{~cm}$ long; primary lateral veins uniformly distributed along the blade. 
4a. Petioles $9-33 \mathrm{~cm}$ long, the sheath $2-3 \mathrm{~cm}$ wide (when flattened), usually extending over the base of the blade, rounded at the apex; blades $13-34 \mathrm{~cm}$ long; peduncle 6-8 cm long (to 10 $\mathrm{cm}$ long in fruit); fruiting spathe tube $8-10 \mathrm{~cm}$ long.

2. S. llanoense

4b. Petioles 6-10 cm long, the sheath less than $1 \mathrm{~cm}$ wide (when flattened), usually ending well below the base of the blade, acute at the apex; blades $14-23 \mathrm{~cm}$ long; peduncle to $4 \mathrm{~cm}$ long (in fruit); fruiting spathe tube ca. $4 \mathrm{~cm}$ long.

3. S. oduberi

2b. Leaf blades ovate to hastate or sagittate, conspicuously lobed at the base; petioles sheathed $1 / 3-3 / 4$ their length.

5a. Stems glaucous; juvenile blades thick, cordate; adult blades thick, the veins not prominent.

\section{S. chiapense}

5b. Stems not glaucous; juvenile blades thin, often hastate or sagittate; adult blades thin, the veins prominent.

6a. Adult blades markedly hastate with pronounced, pointed, posterior lobes directed outward at ca. $45^{\circ}$ angle, the anterior lobe somewhat constricted at the base.

6b. Adult blades ovate, oblong-ovate or elliptic-hastate, not markedly hastate, the posterior lobes rounded or, if pointed, then much smaller than the anterior lobe, usually directed mostly downward, the anterior lobe usually not markedly constricted at the base (except $A$. hastiferum).

7a. Blades with the lower surface pale, matte, whitish; basal veins fusing to form a posterior rib more than $3 \mathrm{~cm}$ long; Costa Rica and Panama.

13. S. schottianum

7b. Blades with the lower surface semiglossy or matte but never whitish; basal veins forming a distinct posterior rib or nearly free to the base.

8a. Blades elliptic-hastate, usually weakly or strongly constricted between the anterior and posterior lobes, the posterior lobes usually narrowly angular; Costa Rica.

9. S. hastiferum

8b. Blades ovate or oblong-ovate, not constricted between the anterior and posterior lobes, the posterior lobes rounded or obtuse, not acutely angular; Mexico or South America and western Panama.

9a. Blades lacking a well-developed posterior rib (united basal vein), the posterior rib lacking or less than $1 \mathrm{~cm}$ long, the basal veins all or nearly all submarginal to the sinus; spathe tube less than $5 \mathrm{~cm}$ long at anthesis.

10a. Blades broadest at the base or in the lower third; primary lateral veins 59 pairs, unbranched; tertiary veins distinct, irregular and wavy, relatively remote from one another; western Venezuela.

10b. Blades broadest at about the middle; primary lateral veins 9-15 pairs, with distinct branches at least in the lower part of the blade; tertiary veins obscure, regular and closely parallel; northern Colombia (Chocó).

5. S. chocoanum

9b. Blades with a well-developed posterior rib usually more than $1 \mathrm{~cm}$ long, the posterior rib naked for some distance from the apex of the sinus; spathe tube usually $6.5-15 \mathrm{~cm}$ long at anthesis; northern South America or Mexico.

11a. Blades less than $35 \mathrm{~cm}$ long; primary lateral veins in 3 or 4 pairs; spadix less than $8 \mathrm{~mm}$ diam. at the broadest point; northern Colombia (Chocó).

11b. Blades mostly more than $35 \mathrm{~cm}$ long; primary lateral veins in 9-13 pairs; spadix 1-2.5 cm diam. at the broadest point.

12a. Spathe blade long-acuminate at the apex; northern Oaxaca (Mexico).

12b. Spathe acute or short-acuminate at the apex; Colombia, Ecuador and 12. S. sagittatum Venezuela.

13a. Blades dark green, thin (drying blackened and papyraceous); primary lateral veins red, in moderately deep valleys; tertiary veins distinct on drying; spathe tube elliptic, light orange-red, conspicuously constricted at the apex, the blade light orange-red throughout.

7. S. dodsonianum

13b. Blades subcoriaceous, light green, drying chartaceous, greenish brown; primary lateral veins green, not markedly sunken in valleys; tertiary veins moderately obscure on drying; spathe tube oblong-elliptic, medium green, only moderately constricted at the apex, the blade creamy white throughout. ---- 6. S. crassifolium

1b. Leaf blades either trilobed, trisect, 5-11-pedatisect or incised-lobate.

14a. Blades incised-lobate; Guatemala and Mexico.

14. S. steyermarkii

14b. Blades trilobed, trisect or 5-11-pedatisect.

15a. Spathe tube cylindroid, frequently more than $6 \mathrm{~cm}$ long; spathe blade usually twice as long as the staminate part of the spadix; fruiting spadix elongate, \pm cylindroid; West Indies.

15b. Spathe tube usually ellipsoid or ovoid (oblong-ovoid in $S$. atrovirens), rarely more than $6 \mathrm{~cm}$ long (to $8 \mathrm{~cm}$ in $S$. neglectum, to $7 \mathrm{~cm}$ in $S$. atrovirens and $S$. chiapense); spathe blade usually only slightly longer than the staminate part of the spadix; fruiting spadix \pm ellipsoid; Central and South America and Trinidad. 
16a. Adult blades trisect or trilobed, sometimes appearing almost 5-parted because of conspicuous auricles on lateral segments.

17a. Blades with the lateral segments merely inequilateral, not markedly auriculate or if markedly auriculate, the auricle at least not pinched off to appear like another segment.

18a. Median lobe of the adult blade with the primary lateral veins departing the midrib at almost $90^{\circ}$ angle (rarely at less than $65^{\circ}$ angle).

19a. Lateral leaflets scarcely unequal at the base, not at all auriculate; Ecuador on the Atlantic slope.

19b. Lateral leaflets noticeably unequal at the base, sometimes \pm auriculate; Central and South America.

20a. Primary lateral veins of the median leaflet indistinct, scarcely more prominent than the lesser veins; Costa Rica and Panama.

\section{S. laterinervium}

20b. Primary lateral veins of the median leaflet distinct, much more prominent than the lesser veins; South America.

21a. Spathe tube narrowly oblong-ovoid, $5.5-7.2 \mathrm{~cm}$ long, scarcely constricted at the apex; western Venezuela. -..- 16. S. atrovirens

21b. Spathe tube oblong-elliptic, 3-3.5 cm long, conspicuously constricted at the apex; western Amazon Basin, Brazil, Peru and Bolivia.

33. S. yurimaguense

18b. Median lobe of the blade with the primary lateral veins in the lower third of the leaflet sharply ascending, departing the midrib at usually less than $60^{\circ}$ angle. 22a. Lateral segments of the adult blade with a conspicuous, usually \pm hastate auricle.

23a. Young leaves, peduncle and spathe tube pruinose; leaves $30-45 \mathrm{~cm}$ wide; highland species occurring in wet forest at elevations above $1300 \mathrm{~m}$ in Chiriquí (western Panama) and Costa Rica.

20. S. glaucopetiolatum

23b. Young leaves, peduncle and spathe tube not pruinose; leaf blades less than $25 \mathrm{~cm}$ wide (rarely to $35 \mathrm{~cm}$ wide in $S$. salvadorense); principally lowland species occurring below $700 \mathrm{~m}$, primarily in tropical forest on the Pacific slope from Chiapas, Mexico, and Guatemala to Panama.

24a. Peduncle $9-18 \mathrm{~cm}$ long (to $25 \mathrm{~cm}$ long in fruit); leaf blades with 3-5 primary lateral veins on each side, these mostly restricted to the lower half of the blade; stems usually pruinose; southern Mexico to El Salvador.

28. S. salvadorense

24b. Peduncle $3.5-9 \mathrm{~cm}$ long; leaf blades with 6 or more primary lateral veins on each side, \pm equally distributed throughout the blade; stems not pruinose; Costa Rica and Panama. ......

25. S. mauroanum

22b. Lateral segments not prominently auriculate or, if auriculate, the auricle at least not at all hastate.

25a. Leaf blades merely trilobed with the segments markedly confluent and less than $12 \mathrm{~cm}$ long (confluent in $S$. chiapense and $S$. podophyllum but these have a median lobe more than $16 \mathrm{~cm}$ long); rare species from Ecuador.

21. S. harlingianum

25b. Leaf blades with usually 3 distinct leaflets (except $S$. chiapense, usually unlobed, and sometimes $S$. podophyllum.

26a. Lateral segments with the auricles moderately conspicuous and directed downward, more or less in line with the midrib of the segment; stems, petioles and peduncles glaucous or the segments silky due to conspicuous papillae on the upper surface; spathe tube dark red inside.

27a. Stems, petioles and peduncles glaucous; blades not silky pubescent due to papillae on the surface. 22. S. hoffmannii

27b. Stems, petioles and peduncles not glaucous; blades silky on the upper surface due to papillae. - - 32. S. wendlandii

26b. Lateral segments with auricles conspicuous or not, but usually not directed downward more or less in line with the midrib of the segment; plants lacking silky upper blade surfaces; plants usually not glaucous or if glaucous, the lateral segments definitely lacking conspicuous auricles, spathe tube variously colored within.

28a. Lateral leaflets narrowly acute to attenuate at the base, not the least auriculate.

29a. Inflorescence solitary; stems less than $1 \mathrm{~cm}$ diam., densely and minutely papillate; below $500 \mathrm{~m}$, Honduras to Costa Rica. 30. S. standleyanum 
29b. Inflorescences paired; stems ca. $2 \mathrm{~cm}$ diam., smooth; above $1000 \mathrm{~m}$ elevation, Peru.

19. S. gentryanum

28b. Lateral leaflets usually conspicuously inequilateral and auriculate (or at least with the outer margin broadly rounded).

30a. Leaf blades thin, the veins conspicuously sunken (when fresh).

31a. Median leaflet with 5-9 pairs of primary lateral veins, drying greenish brown; juvenile blades sagittate; inflorescences 1 or 2 per axil; tropical moist and premontane moist forest, Costa Rica and Panama. 25. S. mauroanum

31b. Median leaflet with 10-16 pairs of primary lateral veins, drying black; juvenile blades elliptic; inflorescences 1-5 per axil; tropical wet and premontane wet forest, Honduras to Panama.

30b. Leaf blades moderately thick
veins not conspicuously sunken.

32a. Blades mostly less than $20 \mathrm{~cm}$ long, the lateral leaflets mostly narrowly rounded at the apex; juvenile leaves purplish violet on the lower surface; adult blades and stems drying conspicuously brown; tropical moist and premontane wet forest, central Panama.

18. S. erythrophyllum

32b. Blades mostly more than $20 \mathrm{~cm}$ long (sometimes less in $S$. standleyanum and $S$. mauroanum), the lateral leaflets usually acute at the apex; juvenile leaves green beneath; adult blades and stems drying mostly green to black (the stems sometimes drying brown).

33a. Peduncles 1-3 per axil, usually more than $9 \mathrm{~cm}$ long, frequently $14-25 \mathrm{~cm}$ long in fruit.

34a. Juvenile blades broadly ovate-cordate; adult blades thick, the median segments $28-52 \mathrm{~cm}$ long, the lateral segments smaller $(10-20 \mathrm{~cm}$ long), directed nearly backwards; peduncle and spathe tube blue glaucous; Mexico (Chiapas, mostly eastern, and southern Veracruz). $\quad$ 4. S. chiapense

34b. Juvenile blades hastate or sagittate; adult blades thin, the median lobe less than $28 \mathrm{~cm}$ long, the lateral segments not markedly smaller, mostly directed forward; peduncle and spathe tube green; southwestern Mexico (Chiapas) and western Guatemala to Costa Rica. 28. S. salvadorense

33b. Peduncles 4-11 per axil, usually less than $9 \mathrm{~cm}$ long, to $13 \mathrm{~cm}$ long in fruit. --- 27a. S. podophyllum var. podophyllum

17b. Blades with the lateral segments bearing conspicuous auricles, these pinched off to appear like separate segments (some leaf blades of $S$. triphyllum with the lateral segments not pinched off).

35a. Stems with large, elongate projections.

27b. S. podophyllum var. peliocladum

35b. Stems lacking elongate projections.

36a. Upper blade surface silky due to papillae; Costa Rica.

36b. Upper blade surface lacking papillae.

37a. Median leaflet with $10-16$ pairs of prominently sunken primary lateral veins; spathe tube red inside.

37b. Median leaflets with usually fewer than 8 pairs of primary lateral veins, these not conspicuously sunken; spathe tube green or red to violet purple inside.

38a. Spathe tube red to violet purple inside; inflorescences $1-4$ per 
axil, usually no more than 3 ; blades usually drying black; tropical wet, premontane wet or more commonly lower montane rainforest, Costa Rica to Panama. -_._. 22. hoffmannii

38b. Spathe tube green inside; inflorescences 4-11 per axil; blades usually drying green.

39a. Stems not glaucous, sometimes with numerous rough emergences; leaf segments usually slender, of nearly equal size and shape; petioles subterete, usually with a sharp medial rib; rachis usually gradually curved, not angular between each segment; staminate flowers deeply retuse at the apex, showing no indication of the line of fusion; Mexico to Costa Rica. -_._-_ 15. S. angustatum

39b. Stems glaucous (at least in northern Central America), smooth, lacking any emergences; leaf segments usually somewhat unequal, not of relatively uniform size and shape; petioles subterete or with only an obtuse medial rib; staminate flowers truncate at the apex with an indication of the line of fusion; Mexico to Panama. 27a. S. podophyllum var. podophyllum

16b. Adult blades either 5-11-pedatisect or incised lobate (i.e., the segments of the anterior lobe pinnate).

40a. Stems with conspicuous, elongate, projections; sea level to $1000 \mathrm{~m}$, Costa Rica and Panama on the Atlantic slope (Alajuela to Bocas del Toro).

27b. $S$. podophyllum var. peliocladum

40b. Stems lacking conspicuous, elongate projections; geographical ranges various.

41a. Peduncles usually 1 (sometimes 2 or 3); entire inflorescence usually $20-40 \mathrm{~cm}$ long (or in $S$. mauroanum less than $20 \mathrm{~cm}$ long with the leaf blades thin and with many sunken veins); spathe tube not glaucous; staminate part of the spadix 8.5-14 cm long (or less in S. mauroanum); Mexico, Costa Rica and Panama.

42a. Inflorescence less than $20 \mathrm{~cm}$ long; staminate part of the spadix less than $8 \mathrm{~cm}$ long; stems less than $1.5 \mathrm{~cm}$ diam.; premontane moist forest, western Panama and Costa Rica. -........ 25. S. mauroanum

$42 \mathrm{~b}$. Inflorescence usually more than $20 \mathrm{~cm}$ long; staminate part of the spadix more than $8 \mathrm{~cm}$ long; stems more than $1.5 \mathrm{~cm}$ diam.; blades chartaceous, the veins not sunken; not occurring in premontane moist forest, Mexico.

26. S. neglectum

41b. Peduncles usually numerous (unless collected when flowers are first beginning to develop); entire inflorescence usually less than $20 \mathrm{~cm}$ long; spathe tube often glaucous; staminate part of spadix 2.5-9 cm long; Mexico to Ecuador, Brazil and Bolivia.

43a. Adult leaf blades thick, the upper surface very smooth, the median leaflet often more than $35 \mathrm{~cm}$ long; juvenile blades thick, large, cordate; peduncles $10-20 \mathrm{~cm}$ long; spathe tube usually glaucous, even in fruit; mature infructescence usually more than $10 \mathrm{~cm}$ long, $5-8 \mathrm{~cm}$ wide

43b. Adult leaf blades thin, the upper surface not smooth, the median leaflet usually less than $35 \mathrm{~cm}$ long; juvenile leaves thin, sagittate or hastate (or if cordate, very small); peduncles less than $10 \mathrm{~cm}$ long at anthesis; spathe tube usually not glaucous in fruit; mature infructescence usually less than $10 \mathrm{~cm}$ long, $4.5 \mathrm{~cm}$ wide.

44a. Stems not glaucous, sometimes with numerous rough emergences; leaf segments usually slender, of nearly equal size and shape; petioles subterete, usually with a sharp medial rib; rachis usually gradually curved, not angular between the segments; staminate flowers deeply retuse at the apex, showing no indication of the line of fusion; Mexico to Costa Rica.

15. S. angustatum

44b. Stems glaucous (at least in northern Central America), smooth, lacking any emergences; leaf segments usually somewhat unequal, not of relatively uniform size and shape; petioles subterete or with only an obtuse medial rib; staminate flowers truncate at the apex with an indication of the line of fusion; Mexico to Panama.

27a. S. podophyllum var. podophyllum

\section{A. Syngonium section Oblongatum Croat, sect. nov. TYPE SPECIES: Syngonium llanoense Croat.}

Lamina adulta oblonga aut oblonga-elliptica, basi subcordata; petiolus vaginatus prope usque ad apicem; lamina juvenalis intermediaque laminae adultae similis. 
1. Syngonium armigerum (Standley \& L. O. Williams) Croat, comb. nov.

Philodendron armigerum Standley \& L. O. Williams, Ceiba 3:107. 1952. TYPE: Costa Rica, Cartago, on hills near Moravia (SE of Turrialba) on road past Tuis, $1300 \mathrm{~m}$, L. O. Williams 16170 (EAP, holotype; US, isotype). NOTE: The original description gave Limón Province as the location. However, Moravia is considerably to the west of the Limón border.

Scandent hemiepiphyte; stems 5-6 mm diam., drying brown with longitudinal wrinkles; internodes $2-4 \mathrm{~cm}$ long; leaves persisting at all nodes at least in the upper $30 \mathrm{~cm}$ of the stem; petioles $5-7 \mathrm{~cm}$ long, (that of the leaf subtending the inflorescence to $10 \mathrm{~cm}$ long), sheathed nearly to the apex, the sheath $5-7 \mathrm{~mm}$ wide when flattened, emarginate at the apex; blades simple, membranous, oblong to oblong-elliptic, 8-15 cm long, 3-6 cm wide, acute to narrowly rounded at the apex, apiculate, weakly lobed at the base, the lobes broadly triangular or rounded, obtuse, the lower surface with obscure black punctations, 5-7 veined at base; primary lateral veins 5-6 pairs all arising in the basal half of the blade, ascending at a sharp angle to the margin near the apex, each forming a separate collective vein; tertiary veins distinct. Inflorescences usually one per axil; peduncles to 5.3 $\mathrm{cm}$ long, $5 \mathrm{~mm}$ diam. (dried); fruiting spathe coriaceous, ca. $7 \mathrm{~cm}$ long. Infructescences not seen. Fig. 1 .

Distribution: The species is known only from the type locality, which is an area of premontane wet forest or premontane rain forest.

The type collection made in April was in mature fruit.

Costa Rica: lımón: Near Moravia, Williams 16170 (EAP, US).

2. Syngonium llanoense Croat, sp. nov. TYPE: Panama, Canal Zone, Summit Gardens (no doubt collected originally in Panamá or Colón Province), Croat 17148 (MO-219002, holotype).

Caudex haud glaucus, ca. $2 \mathrm{~cm}$ diam.; foliorum petiolus 9-27 cm longus, ad apicem vaginatus; lamina oblongata-elliptica, $18-28 \mathrm{~cm}$ longa, 8-11 cm lata, apice acuminata, basi rotundata ad subcordata. Inflorescentia usque 2 in axilla; spathae tubus $5-6 \mathrm{~cm}$ longus, ca. $3 \mathrm{~cm}$ latus, viridis; spathae lamina e viridi alba, ca. $10 \mathrm{~cm}$ longa; spadix $11.5 \mathrm{~cm}$ longa; parte mascula spadicis ca. $9.5 \mathrm{~cm}$ longa, alba, parte feminea spadicis viridi, $2 \mathrm{~cm}$ longa, basi $9 \mathrm{~mm}$ diam., apice $6 \mathrm{~mm}$ diam. (in sicco).

Juvenile plants with trailing stems, the leaves much like those of the adult but smaller; stems medium green when young, becoming dark olive-green to purplish; internodes 3-6 cm long, to $6 \mathrm{~mm}$ wide, weakly sulcate above the petioles in the lower part of the internode; petioles $6 \mathrm{~cm}$ or longer, sheathed nearly throughout; the sheath $1-1.3 \mathrm{~cm}$ wide when flattened. Adult plants with stems closely appressed to trees, dark olive-green, shiny, to ca. $2 \mathrm{~cm}$ diam., becoming brown in age, drying with longitudinal wrinkles; internodes to $5 \mathrm{~cm}$ or more long on the lower parts of the stem, 1-3 cm near the apex; sap pale tan; leaves persisting on the upper $1 \mathrm{~m}$ or more of the stem; petioles $9-33 \mathrm{~cm}$ long, broadly sheathed almost throughout, broadly canaliculate from the end of the sheath to the blade, the sheath $2-3 \mathrm{~cm}$ wide when flattened (to $5 \mathrm{~cm}$ wide when subtending an inflorescence), the margins of the sheath erect at the base, broadly spreading toward the apex, free-ending and emarginate at the apex (with the apical lobes sometimes extending beyond the bottom of the blade); blades simple, oblong-elliptic to ovateelliptic, gradually acuminate and turned down at the apex (the acumen apiculate), narrowly rounded to subcordate at the base, $13-34 \mathrm{~cm}$ long, 6-13 cm wide, the 

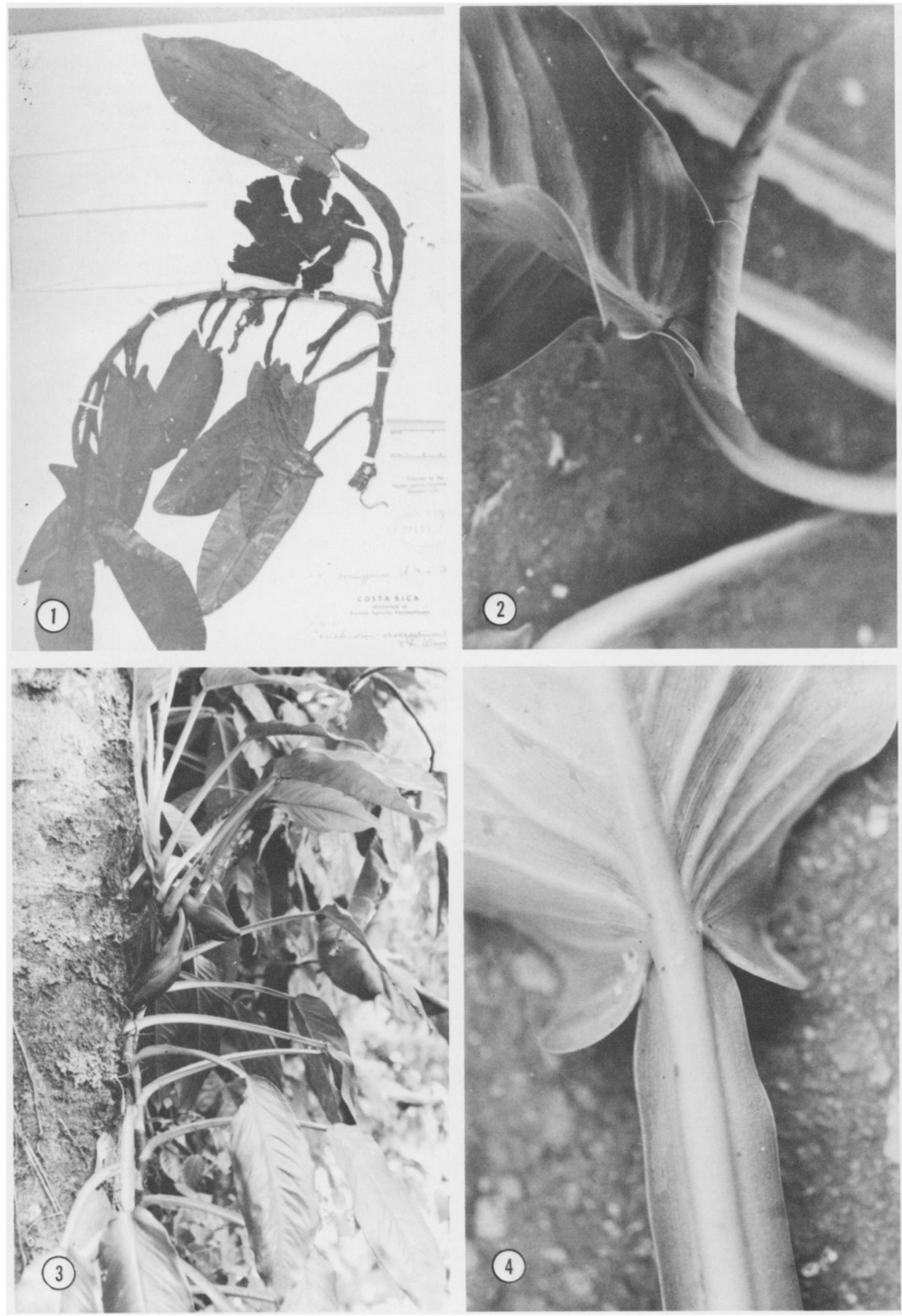

FIGURES 1-4.-1. Syngonium armigerum, Williams 16170; plant bearing mature infructescence.2. S. llanoense, Croat 17148; base of blade with free-ending petiole sheath (new leaf emerging from sheath) $\left(x^{1 / 3}\right)$. - 3. S. llanoense, Croat 36946; plant bearing young infructescences $\left(x^{1 / 10}\right) .-4 . S$. llanoense, Croat 17148; base of lower surface of blade showing petiole sheath $\left(x^{5 / 7}\right)$. 
posterior lobes 1-2 $\mathrm{cm}$ long, held almost erect, rounded at the apex, the upper surface medium green, matte to semiglossy, the lower surface much paler, matte; midrib prominently sunken; primary lateral veins 10-18 pairs, sunken above, raised beneath; interprimary veins few; tertiary veins distinctly visible; principal collective vein weakly sunken, 4-8 $\mathrm{mm}$ from the margin, weakly loop-connected between the primary veins. Inflorescences usually 2 per axil, erect at anthesis; prophylls ca. $20 \mathrm{~cm}$ long; peduncles $6-8 \mathrm{~cm}$ long, the epidermis in part becoming inflated on drying; spathe tube green, ovoid-ellipsoid, $5-6 \mathrm{~cm}$ long, ca. $3 \mathrm{~cm}$ diam.; spathe blade greenish-white, ca. $10 \mathrm{~cm}$ long, acuminate at the apex; spadix $11.5 \mathrm{~cm}$ long (on dried plants); pistillate portion of the spadix green, ca. $2 \mathrm{~cm}$ long, ca. $9 \mathrm{~mm}$ diam. at the base, ca. $6 \mathrm{~mm}$ diam. at the apex; staminate and sterile portions of the spadix $9.5 \mathrm{~cm}$ long, white, the sterile staminate portion ca. $12 \mathrm{~mm}$ diam., the staminate flowers mostly ca. $2 \mathrm{~mm}$ diam., the sterile flowers mostly 4-5 mm diam. Infructescences pendent; peduncles green, weakly flattened, to $10 \mathrm{~cm}$ long, fruiting spathe oblong-elliptic, 8-10 cm long, $3-4.5 \mathrm{~cm}$ diam., fruiting spadix subglobose, ca. $5 \mathrm{~cm}$ long, $4 \mathrm{~cm}$ diam., tan cream; seeds subglobose, ca. $8 \mathrm{~mm}$ diam. Figs. 2-4, 21.

Distribution: Syngonium llanoense was first collected at Summit Garden but later discovered in both Panamá and Colón provinces in areas adjacent to the Canal Zone. It occurs naturally only in tropical wet forest life zones.

The species is unique among known members of the genus in having oblongelliptic leaves. Another distinguishing feature is the petiole which is sheathed throughout its length.

Flowering inflorescences have been seen in June and fruits have been found in June, July, and October.

Panama: Canal zone: Summit Gardens, Croat 10831 (DUKE, MO, SCZ), 17148, 35999 (MO). Colón: Río Guanche, Croat 36946 (MO); Vicinity of Río Indio, Croat 33636A (MO). PANAMÁ: El Llano-Cartí Road, Croat 25148, 34764, Kennedy 1785 (MO).

3. Syngonium oduberi Ray, Aroideana 3:128. 1980. TYPE: Costa Rica, Osa Peninsula, Corcovado National Park, Ray 4 (GH, holotype).

Juvenile plants with trailing stems; internodes 4-7 mm long, $3 \mathrm{~mm}$ wide; leaves much like those of the adult but smaller and narrower; petioles $4.5-5.5 \mathrm{~cm}$ long; blades $13-15 \mathrm{~cm}$ long, $3.5-4.5 \mathrm{~cm}$ wide. Adult plants with stems closely appressed to trees; internodes 1-2 cm long, ca. $6 \mathrm{~mm}$ wide; petioles $6-10 \mathrm{~cm}$ long, sheathed throughout except for the apical $0.5-1 \mathrm{~cm}$, the sheath free-ending and apiculate at the apex, not extending beyond the base of the blade, the apical part flattened adaxially with a medial rib, the margins acute; blades simple, oblong-elliptic, gradually acuminate at the apex, slightly constricted above the posterior lobes (less so on juvenile blades), 14-23 cm long, 6-8 cm wide, the posterior lobes bluntly acute, 8-13 mm long; primary lateral veins 12-14 on each side, sunken above, raised beneath; tertiary veins prominent; latex not milky though slightly orange in mature stems. Infructescences pendent; peduncles $3.5 \mathrm{~cm}$ long; fruiting spadix $4 \mathrm{~cm}$ long, $2.5 \mathrm{~cm}$ diam. The flowering spadix has not been seen; a nearly mature fruit was collected in July. Figs. 13-14. 
DISTRIBUTION: Syngonium oduberi has been collected only once, in wet forest, at ca. $100 \mathrm{~m}$ elevation.

The species is distinguished by its oblong-elliptic leaves and almost fully sheathed petioles. It is most closely related to $S$. llanoense from the isthmus of Panama. It is distinguished from that species in having smaller leaves and stems, in having the posterior lobes bluntly acute (versus rounded in $S$. llanoense) and in having the sheath end well below the blade. In $S$. llanoense the sheath generally extends beyond the base of the blade.

Costa Rica: Puntarenas: Parque Corcovado, Osa Peninsula, near Llorana, 100 m, Ray 4 (GH).

B. Syngonium section Cordatum Croat, sect. nov. TYPE SPECIES: Syngonium schottianum Wendl.

Lamina adulta simplex, lobis posticis bene evolutis; petiolus e $1 / 2$ ad $4 / 5$ longitudinis usque vaginatus; lamina juvenalis intermediaque laminae adultae similis.

4. Syngonium chiapense Matuda, Revista Soc. Mex. Hist. Nat. 11:94-95. 1950. TYPE: Mexico, Chiapas, Piedra de Huixtla, Matuda 18619 (MEXU, holotype; DS, isotype).

S. llamasii Matuda, Cact. \& Sucul. Mexico 2:79, fig. 52. 1957. TYPE: Mexico, Chiapas, El Suspiro, near Ocozocuautla, $600 \mathrm{~m}$, Matuda 32637 (MEXU, holotype).

Juvenile plants with glaucous stems; internodes $5-23 \mathrm{~cm}$ long, less than $1 \mathrm{~cm}$ wide; petioles sheathed $1 / 2-3 / 4$ their length, blades ovate-cordate, 9-30 cm long, 5-17 cm wide, acuminate at the apex. Adult plants with stems green, usually glaucous; internodes $12-20 \mathrm{~cm}$ long, becoming closer at the apex, 2-6 cm long, $2.5-4 \mathrm{~cm}$ diam.; petioles $30-60 \mathrm{~cm}$ long, sheathed about $4 / 5$ their length, subterete above the sheath, weakly flattened on the upper surface; blades with the upper surface matte, seldom weakly glossy, the lower surface matte, much paler, ovatecordate to 3-lobed, abruptly acuminate to obtuse-mucronate at the apex, the entire blade with the anterior lobe $28-65 \mathrm{~cm}$ long, $18-35 \mathrm{~cm}$ wide, broadest at about the middle, only slightly or not at all constricted at the base, the posterior lobes rounded or subhastate, the sinus very narrow or open and broader than deep, the posterior rib sometimes naked 5-20 mm; 3-lobed blades with the anterior lobe broadly ovate, $28-52 \mathrm{~cm}$ long, abruptly constricted at the base and confluent with the posterior lobes, the latter ovate to obovate, $10-20 \mathrm{~cm}$ long, directed backwards or at ca. $90^{\circ}$ angle to the anterior lobe, acute to narrowly rounded at the apex, bluntly auriculate at the base on the lower side; primary lateral veins mostly 5-8(-10) pairs, slightly sunken; the primary lateral veins convexly raised, the tertiary veins clearly visible. Inflorescences $1-3$; peduncles to ca. $10 \mathrm{~cm}$ long and erect at anthesis, green and glaucous, $12-18 \mathrm{~cm}$ long and pendent in fruit; spathe tube ellipsoid to oblong-ovoid or cylindroid, greenish outside, glaucous, 5-7 cm long, to $3 \mathrm{~cm}$ diam. inside, yellowish white at the base, purplish at the apex; spathe blade broadly elliptic, white, shortly cuspidate at the apex, 5-9 cm long, 5-7 cm wide; pistillate portion of the spadix 3-4 cm long, the ovary ca. $5 \mathrm{~mm}$ long, $3 \mathrm{~mm}$ wide; staminate portion of the spadix ca. $5-9 \mathrm{~cm}$ long, to $1.5 \mathrm{~cm}$ diam., the staminate flowers ca. $3 \mathrm{~mm}$ long, the anthers 4 , cross- 

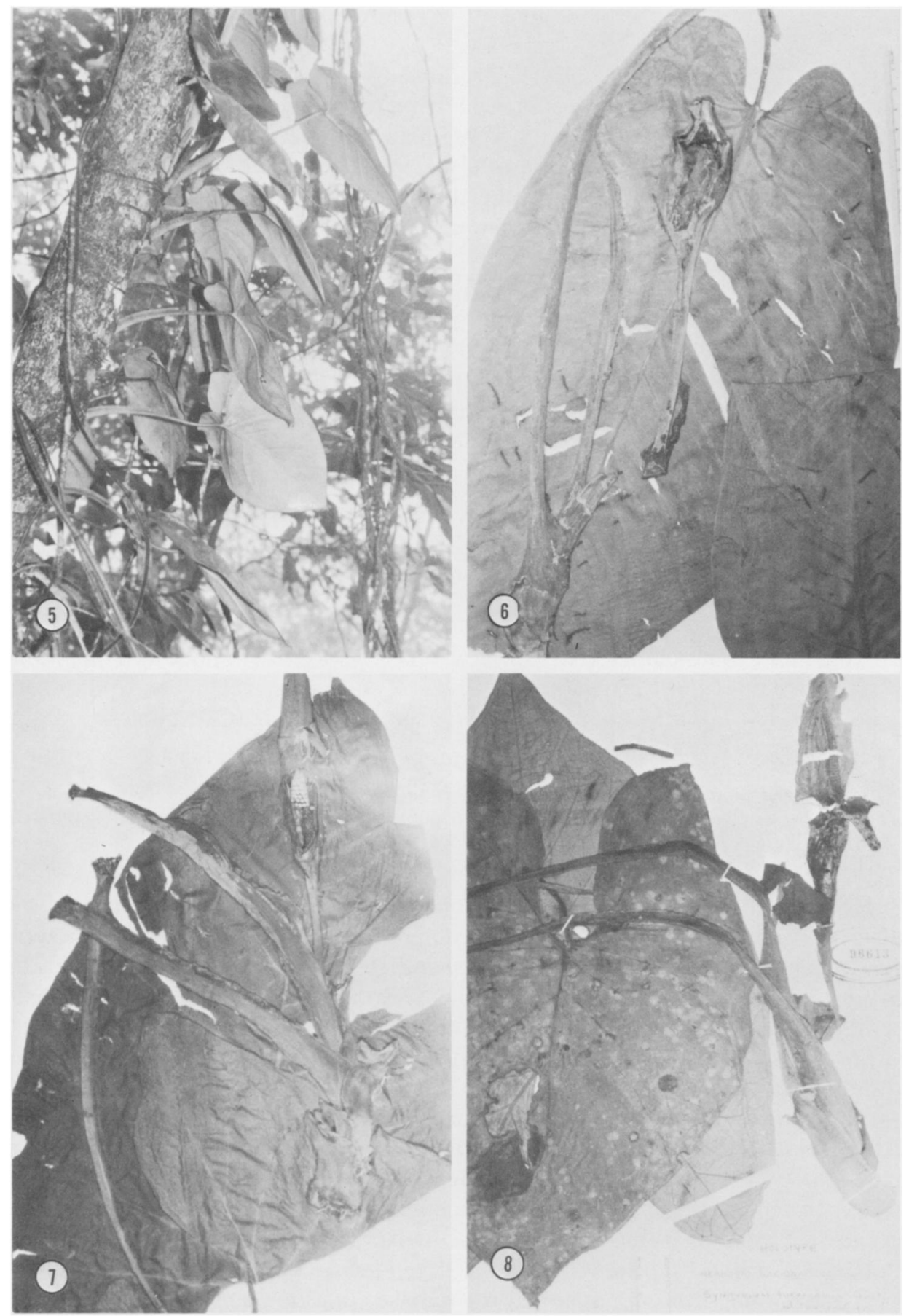

FIGURES 5-8.-5. Syngonium chiapense, Croat 48016; adult plant $\left(\times^{1 / 20}\right)$.-6. S. chocoanum, Forero et al. 3324; adult blade with infructescence.-7. S. dodsonianum, Dodson \& Gentry 10063; adult blade and inflorescence $\left(\times^{1 / 3}\right) .-8$. S. foreroanum, Forero et al. 3385 ; adult blade and inflorescence $\left(x^{1 / 4}\right)$. 
shaped. Infructescences usually rather massive, bluish glaucous, \pm ellipsoid, ca. 8-10 cm long, 4.5-5 cm diam. Figs. 5, 22.

Distribution: Syngonium chiapense is known for certain only from southern Mexico (Oaxaca and southern Veracruz), but a sterile collection from Guatemala (Baja Verapaz) also appears to be this species. The species occurs only on the Atlantic coast from sea level to more than $1200 \mathrm{~m}$ but most commonly occurs above $350 \mathrm{~m}$ in life zones ranging from tropical moist forest through tropical wet forest.

Syngonium chiapense is perhaps most closely related to $S$. macrophyllum. The two species have nearly identical juvenile leaves and both have glaucous stems and inflorescences in Mexico. The adult foliage of $S$. macrophyllum with 7-9 free leaflets is never confused with this species which is commonly entire or with merely a single pair of confluent posterior lobes.

Fruits have been seen July-September.

Guatemala: baja verapaz: S of Purulha, Croat 41218 (MO).

MeXICo: CHIAPAS: Comaltitlán, Matuda 17882 (MEXU); N of Ocozocoautla, Croat 40662 (MO); Piedra de Huixtla, Matuda 18619 (DS, MEXU). OAXACA: Vicinity of Valle Nacional, Croat 39720, 39754, 39805, 43913 (MO), 48016 (CAS, MO, MEXU), Moore \& Bunting 8895 (BH, MO). VERACRUZ: E of Coatzacoalcos, Croat 40060 (MO); S of Catemaco, Moore \& Bunting 8926 (MO), 8938 (BH, MO).

5. Syngonium chocoanum Croat, sp. nov. TYPE: Colombia, Chocó, Municipio of Nóvita, slope $\mathrm{N}$ of Cerro Torrá Filo ridge $\mathrm{E}$ of Río Surama, along trail to Alto del Oso, 500-600 m, Forero, Gentry, Sugden \& Daly 3324 (COL, holotype; MO2604930 , isotype).

Planta hemiepiphytica; caudex ca. $2 \mathrm{~cm}$ diam., internodiis brevibus; lamina simplex; petiolus usque $5-6 \mathrm{~cm}$ e apice vaginatus; lamina anguste ovata, basi cordata; folia venis lateralibus utroque latere 9-15, infimis ramosis; venis tertiariis tenuibus, approximatis, obscuris. Inflorescentia ignota; spatha fructifer viridis, oblonga-elliptica, $8 \mathrm{~cm}$ longa.

Hemiepiphytic creeper; stems ca. $2 \mathrm{~cm}$ diam.; internodes short, those on the upper part of the stem ca. $1 \mathrm{~cm}$ long; cataphylls thin, ca. $19 \mathrm{~cm}$ long, ca. $1 \mathrm{~cm}$ wide; petioles to $43 \mathrm{~cm}$ long, narrowly sheathed to within $5 \mathrm{~cm}$ of the apex, the margins of the sheath to $1 \mathrm{~cm}$ high, markedly broadened within $6 \mathrm{~cm}$ of the base, acute and free-ending at the apex (the free part ca. $1.5 \mathrm{~cm}$ long, the unsheathed part of the petiole ca. $3 \mathrm{~mm}$ diam. (dried); blades entire, moderately thin, narrowly ovate, acute or bluntly acuminate at the apex, narrowed and cordate at the base, 26-36 cm long, 14-23 cm wide, the posterior lobes narrowly rounded; primary lateral veins $9-15$ pairs, arising at ca. $45-50^{\circ}$ angle, straight or weakly curved to the collective vein, with prominent branches (especially in the lower half of the blade) these curved and closely paralleling the primary lateral veins; tertiary veins obscure (at least on drying), close, markedly parallel; collective veins 3 , obscure, the first ca. $5 \mathrm{~mm}$ from the margin; basal veins 4 or 5 pairs, the lowermost $3-4$ basal veins coalesced ca. $5 \mathrm{~mm}$ before the base. Inflorescences solitary(?); flowering spathe not seen. Infructescences with the peduncles to $11 \mathrm{~cm}$ long, $6 \mathrm{~mm}$ diam. (dried) midway, smooth, fruiting spathe tube narrowly elliptic, green, $8 \mathrm{~cm}$ long, $4 \mathrm{~cm}$ diam.; syncarp oblong-elliptic, $5.5 \mathrm{~cm}$ long, $4 \mathrm{~cm}$ diam., tan. Fig. 6. 
Distribution: Syngonium chocoanum is known only from the southern part of the Chocó Department, Colombia, in tropical wet forest.

It is apparently related to both $S$. hastiferum from Costa Rica and $S$. meridense from western Venezuela, differing from both in having fine, closely parallel tertiary veins. It differs from $S$. hastiferum in having an open sinus with rounded posterior lobes. It differs from $S$. meridense in having a narrower sinus (versus broad and open in $S$. meridense). In respect to the sinus alone $S$. chocoanum lies intermediate between $S$. hastiferum and $S$. meridense, but the very different venation is sufficient to distinguish the species.

Colombia: chocó: Municipio de Nóvita, N of Cerro Torrá Filo, Forero et al. 3324 (COL, MO); Valley of Río San Juan, Quebrada La Sierpe, Forero et al. 3965 (COL, MO).

\section{Syngonium crassifolium (Engler) Croat, comb. nov.}

Porphyrospatha crassifolia Engler, Bot. Jahrb. Syst. 37:140. 1905. TYPE: Colombia, Antioquia, am Riachon über Amalfi, 1800 m, Lehmann (Sept. 1884) (B, holotype).

Juvenile plants with scandent stems; internodes $10-20 \mathrm{~cm}$ or more long, ca. $1 \mathrm{~cm}$ diam., petioles sheathed to beyond the middle; intermediate stems climbing; petioles $15-20 \mathrm{~cm}$ long, sheathed ca. $2 / 3$ their length; juvenile blades simple, ovateoblong, abruptly acuminate at the apex, weakly hastate at the base, $15-25 \mathrm{~cm}$ long, $8-13 \mathrm{~cm}$ wide, the anterior lobe weakly constricted at the base, the posterior lobes $4-8 \mathrm{~cm}$ long, narrowly rounded to acute at the apex. Adult plants epiphytic or hemiepiphytic, stem to $1 \mathrm{~m}$ or more long, 4-6 cm diam.; internodes to $10 \mathrm{~cm}$ long, much shorter near the apex, yellowish brown on drying; petioles $45-70 \mathrm{~cm}$ long, sheathed $3 / 4$ their length, the upper part weakly flattened adaxially near the base of the blade, becoming obtusely 1-ribbed toward the sheath, the sheath free at the apex; blades entire, ovate-hastate, abruptly acuminate at the apex, conspicuously lobed at the base, $35-70 \mathrm{~cm}$ long, $23-40 \mathrm{~cm}$ wide, the anterior lobe with the sides broadly rounded, sometimes weakly constricted at the base, the posterior lobes directed outward at ca. $45^{\circ}$ angle, $15-25 \mathrm{~cm}$ long, usually narrowly rounded at the apex, the sinus 6-15 cm deep, usually narrow, sometimes as broad as deep, the lower surface slightly paler than the upper surface; primary lateral veins $10-13$ pairs, joining the midrib at ca. $30^{\circ}$ angle, sunken on the upper surface, raised on the lower surface; reticulate veins obscurely visible on the upper surface, clearly visible beneath; posterior rib prominently raised, extending straight to the apex of the posterior lobes, naked $2-3 \mathrm{~cm}$; primary collective vein less than $1 \mathrm{~cm}$ from the margin. Inflorescences several, erect; peduncles $8-15 \mathrm{~cm}$ long; spathe tube pale green, to $7 \mathrm{~cm}$ long, bluntly ribbed adaxially; spathe blade creamy white, oblong-elliptic, 9-11 cm long, constricted at the base and articulating along an elevated ring well above the end of the pistillate part of the spadix; spadix ca. $12 \mathrm{~cm}$ long; pistillate portion of the spadix grayish, $2-3 \mathrm{~cm}$ long, ca. $1 \mathrm{~cm}$ diam.; staminate portion of the spadix creamy white, $8-10.5 \mathrm{~cm}$ long, slightly narrower toward the apex, ca. $1.5 \mathrm{~cm}$ diam. midway, the synandrium regularly 4-lobed and truncate at the apex, weakly incised between the anthers. Infructescences pendent, yellowish, to ca. $9 \mathrm{~cm}$ long and $4.5 \mathrm{~cm}$ diam. Figs. 23, 24. 
Distribution: The species is known from Colombia and Ecuador on the Pacific slope and in Venezuela in the state of Mérida.

The species has been collected in flower from June through October and mature fruits have been seen in late October.

Colombia: antioquia: (Photo) Lehmann 12300 (B, MO, US).

EcuADor: COTOPAXI: Santo Domingo de Los Colorados, Ellenberg 3063 (MO). Los Ríos: Biological Station at Río Palenque, Croat 38661, 38678, 38700 (MO), Dodson 5538 (SEL, US), Gentry $6582,11997(\mathrm{MO})$.

Venezuela: MÉrIDA: Between El Vigía and El Quince, Bunting 2403 (MY).

7. Syngonium dodsonianum Croat, sp. nov. TYPE: Ecuador, Los Ríos, Río Palenque Biological Station, km 56 along the road between Santo Domingo and Quevedo, 150-200 m, Dodson \& Gentry 10063 (MO-2742909, holotype; SEL, isotype).

Planta hemiepiphytica; caudex ca. $2.5 \mathrm{~cm}$ diam., internodiis apice 1-2 $\mathrm{cm}$ diam., 1-2 cm longis; lamina simplex, tenuis, atrovirida; venis lateralibus utroque latere $10-13$, rubris, in vallibus; venis tertiariis distinctis in sicco. Inflorescentia solitaria?; spathae tubus ellipticus, pallide aurantiacus, apice constrictus; spathae lamina pallide aurantiaca.

Hemiepiphytic creeper; stems $2.5 \mathrm{~cm}$ diam.; internodes $1-2 \mathrm{~cm}$ long near the apex, drying brown with close longitudinal wrinkles; petioles $45-73 \mathrm{~cm}$ long, sheathed ca. $2 / 3$ their length, the upper part subterete, the sheath $8-10 \mathrm{~cm}$ high, free-ending at the apex; blades simple, ovate, acute to abruptly acuminate at the apex, conspicuously lobed at the base, $42-53 \mathrm{~cm}$ long, $23-31 \mathrm{~cm}$ wide, thin, dark green (drying dark olive green, papyraceous), the anterior lobe $30-35 \mathrm{~cm}$ long, not at all constricted toward the base, the posterior lobes directed downward or slightly inward, acutely rounded at the apex, sometimes unequal, sometimes weakly constricted near the apex; midrib flat at the base, becoming weakly sunken toward the apex (at least on drying); primary lateral veins 10-13 pairs, reddish, in deep valleys; tertiary veins fine, close, distinct (at least on drying); basal veins $3-5$ pairs, 3 of them coalesced 3-5 cm; posterior rib naked $2.5-3 \mathrm{~cm}$, directed straight to the tip of the posterior lobe; primary collective vein 3-8 $\mathrm{mm}$ from the margin, weakly loop-connecting the primary lateral veins. Inflorescences solitary(?); peduncles ca. $9 \mathrm{~cm}$ long, 5-8 $\mathrm{mm}$ diam. (dried); spathe ca. $15 \mathrm{~cm}$ long; spathe tube ovoid-oblong to oblong-elliptic, $6.5-7.5 \mathrm{~cm}$ long, orange red, prominently constricted at the apex; spathe blade light orange red to yellow orange with reddish veins, acuminate at the apex; spadix ca. $11.5 \mathrm{~cm}$ long; pistillate portion of the spadix grayish, $2-2.5 \mathrm{~cm}$ long, 6-10 $\mathrm{mm}$ diam. on drying, weakly constricted at the apex, ca. $2 \mathrm{~mm}$ long, $1-1.5 \mathrm{~mm}$ diam.; staminate portion of the spadix creamy white, the sterile staminate portion $\mathrm{ca} .2 \mathrm{~cm}$ long, constricted gradually toward the apex, drying 2-3 mm long, $1.5-3 \mathrm{~mm}$ diam., the sterile staminate portion broadest in the lower $1 / 3$, gradually tapered to the apex, drying ca. $1.3 \mathrm{~cm}$ diam., the flowers more or less trapezoidal, the margins weakly crenate, the apex weakly depressed medially with no sign of fusion of the anthers. Infructescences not known. Fig. 7.

Distribution: Syngonium dodsonianum is known only from the type locality at the Río Palenque Biological Station, a region of tropical wet forest at 150-220 $\mathrm{m}$ in western Ecuador. It is to be expected throughout the band of wet forest in western Ecuador and perhaps also in Colombia. 

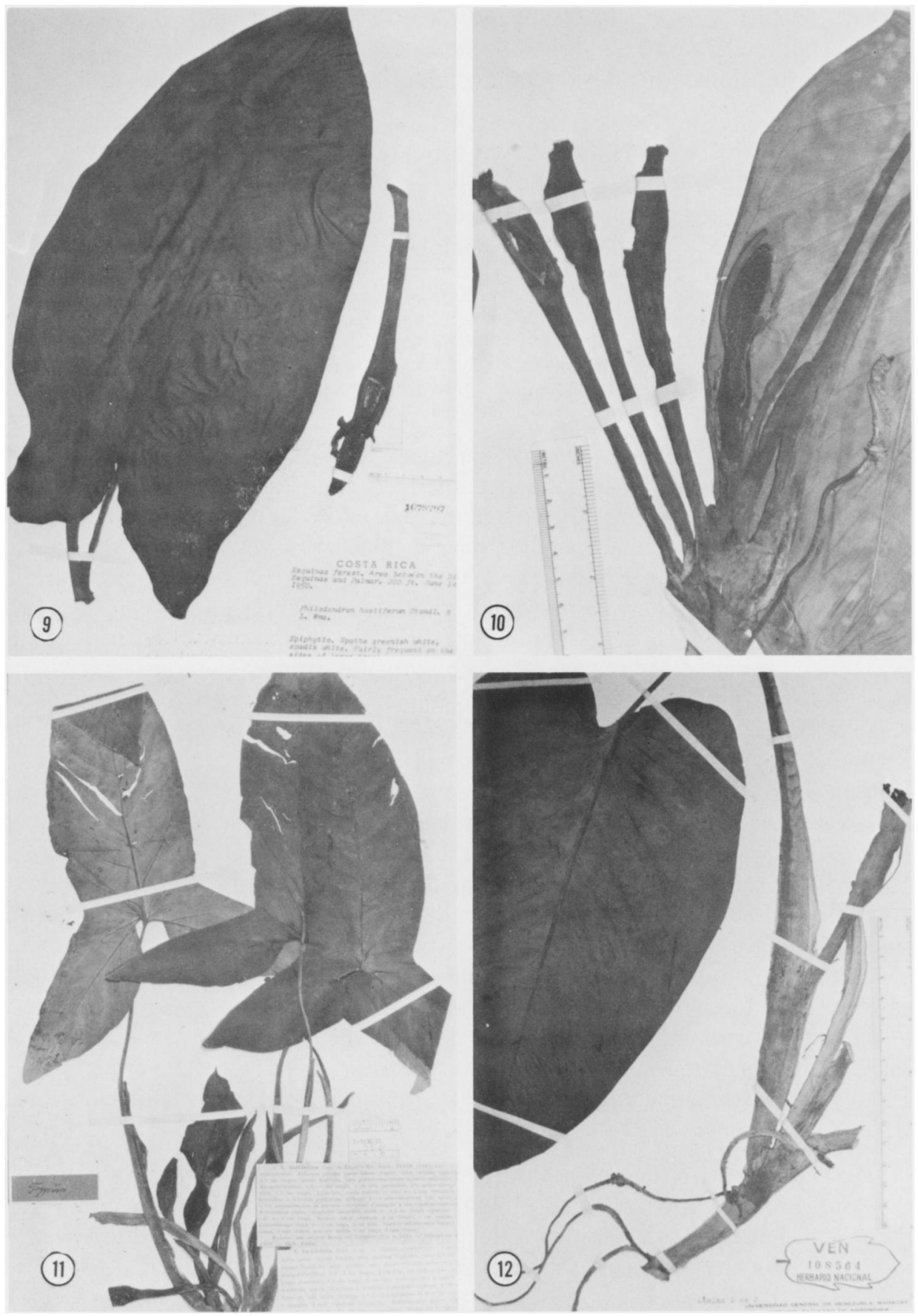

Figures 9-12.-9. Syngonium hastiferum, Allen 5563; adult blade and inflorescence $\left(\times^{1 / 7}\right) .-10$. S. hastiferum, Allen 5563; inflorescence and young infructescences.-11. S. hastifolium, Ule 6010; adult blades and inflorescences $\left(x^{1 / 4}\right),-12$. S. meridense, Bunting 4381; adult blade with young infructescence $\left(x^{1 / 4}\right)$. 
The species is most closely related to $S$. crassifolium with which it is sympatric. It differs from that species by the characters outlined in the key.

Flowering collections have been made during March and September.

Ecuador: los Ríos: Río Palenque Biological Station, Dodson \& Gentry 10063 (MO, SEL).

8. Syngonium foreroanum Croat, sp. nov. TYPE: Colombia, Chocó, Municipio of San José del Palmar, on a hill SW of the village, $1300 \mathrm{~m}$, Forero, Gentry, Sugden \& Daly 3385 (COL-96613, holotype).

Planta hemiepiphytica; petiolus $45-47 \mathrm{~cm}$ longus, usque ad 1/3 longitudinis vaginatus; lamina tenuis, ovata, apice acuminata, lobo antico $17.5-20 \mathrm{~cm}$ longo, lobi posticis $10.5-15 \mathrm{~cm}$ longis, apice acutis obtuse, sinu basali apice obtuso aut rotundato; venis basalibus ad marginem confluentibus 1.2$1.5 \mathrm{~cm}$; folia venis lateralibus utroque latere 3-4. Inflorescentia solitaria?; pedunculus $11-12 \mathrm{~cm}$ longus; spathae tubus oblongus-ellipticus, $6.5 \mathrm{~cm}$ longus; spathae lamina $12 \mathrm{~cm}$ longa; spadix parte feminea $2 \mathrm{~cm}$ longa, fusiformi, parte masculina $7 \mathrm{~mm}$ diam., apice acuta.

Hemiepiphytic creeper; stems $1.5 \mathrm{~cm}$ diam.; upper internodes ca. $1.5 \mathrm{~cm}$ long or shorter; petioles $45-47 \mathrm{~cm}$ long, sheathed $15-17 \mathrm{~cm}$ at the base, the sheath ca. $2 \mathrm{~cm}$ high near the base, weakly free-ending and acute at the apex, the unsheathed part cylindrical, ca. $4 \mathrm{~mm}$ diam. on drying; blades entire, ovate, abruptly acuminate or bluntly acute at the apex, deeply lobed at the base, $28-31 \mathrm{~cm}$ long, 19 $21 \mathrm{~cm}$ wide, drying chartaceous, matte, the anterior lobe $17.5-20 \mathrm{~cm}$ long; the posterior lobes $10.5-15 \mathrm{~cm}$ long, directed somewhat outward, bluntly acute at the apex; sinus rounded at the apex, $2.5-3.5 \mathrm{~cm}$ wide; primary lateral veins $3-4$ per side, arising from the midrib at $35-55^{\circ}$ angle, weakly curved to the collective vein; secondary and tertiary veins distinct, flat; primary collective vein $2-4 \mathrm{~mm}$ from the margin, moderately straight, basal veins usually 3 , the posterior rib straight to the tip of the posterior lobes, naked $12-15 \mathrm{~mm}$ at the base. Inflorescences solitary (?); peduncles 11-12 cm long, ca. $4 \mathrm{~mm}$ diam. (dried); spathe ca. $15 \mathrm{~cm}$ long; spathe tube ca. $6.5 \mathrm{~cm}$ long, ca. $1.6 \mathrm{~cm}$ diam., greenish; spathe blade $4 \mathrm{~cm}$ wide, acuminate (?) at the apex, moderately thin, at least sometimes weakly purplish-spotted throughout; spadix slender, $12 \mathrm{~cm}$ long; pistillate portion of the spadix fusiform, ca. $2 \mathrm{~cm}$ long, $7 \mathrm{~mm}$ diam.; sterile staminate portion of the spadix conspicuously constricted at the base, ca. $2.5 \mathrm{~cm}$ long, gradually broadened onto the fertile portion, the sterile staminate flowers broadest in the direction of the axis, the apex $3-3.5 \mathrm{~mm}$ long, $1.5 \mathrm{~mm}$ broad, the fertile staminate portion ca. $7.5 \mathrm{~cm}$ long, $7 \mathrm{~mm}$ diam., narrowly acute at the apex, the flowers $2 \mathrm{~mm}$ long, $1.5-2.5 \mathrm{~mm}$ diam., irregularly shaped, the margin irregularly scalloped. Infructescences unknown. Fig. 8.

Distribution: Syngonium foreroanum is known for certain only from the type specimen. It was collected at $1300 \mathrm{~m}$ elevation in an area that is probably premontane wet forest. Another specimen collected at sea level (Forero et al. 4367) in the delta of the Río San Juan in southern Chocó might also be this species. It is described as an epiphyte but looks more like a Xanthosoma. It differs principally in having an ovate-triangular blade with narrowly acute lobes.

Syngonium foreroanum is most similar to $S$. crassifolium but differs from it by its smaller leaves, fewer primary lateral veins, and more delicate inflorescences. 
Colombia: chocó: S of Municipio of San José, Forero et al. 3385 (COL).

\section{Syngonium hastiferum (Standley \& L. O. Williams) Croat, comb. nov.}

Philodendron hastiferum Standley \& L. O. Williams, Ceiba 1:232. 1951. TYPE: Costa Rica, Puntarenas, forested hills above Esquinas, in region between Río Esquinas and Palmar Sur de Osa, Allen 5563 (US, holotype).

Juvenile plants hemiepiphytes; stems green, not glaucous, scandent; internodes to $25 \mathrm{~cm}$ or more long, ca. $1 \mathrm{~cm}$ diam., drying brown with thin flaking epidermis; smallest leaves with the petioles sheathed almost to the apex; blades broadly ovate. Intermediate stages with petioles $20-30 \mathrm{~cm}$ long, sheathed to beyond the middle, the unsheathed part of the petiole terete, becoming weakly flattened laterally toward the apex; blades becoming elliptic and weakly cordate, finally with hastate lobes like the adults, then increasing only in size. Adult plants hemiepiphytic creepers; stems to $2 \mathrm{~cm}$ diam. (dried); internodes ca. $2.5 \mathrm{~cm}$ long; petioles to $37 \mathrm{~cm}$ long or longer, sheathed ca. $5 / 6$ their length, the sheath freeending and emarginate at the apex; blades elliptic-hastate, triangular-acuminate at the apex, deeply lobed at the base, ca. $40 \mathrm{~cm}$ long, $28.5 \mathrm{~cm}$ wide, the anterior lobe ca. $30 \mathrm{~cm}$ long, gradually constricted at the base, the sides broadly rounded, the posterior lobes directed downward or slightly outward, narrowly triangular, somewhat unequal, the longer lobe to $12 \mathrm{~cm}$ long (from the apex of the petiole to the tip of the lobe), narrowly rounded at the apex, the shorter lobe to $8 \mathrm{~cm}$ long; sinus very narrow in the apical $2.5 \mathrm{~cm}$, then broadly opening (when flattened), drying thin, the upper surface brown, the lower surface greenish brown; midrib flat or weakly sunken, $4 \mathrm{~mm}$ wide at the base; primary lateral veins ca. 13 pairs, weakly raised, the secondary and tertiary veins clearly visible; principal collective vein $8-12 \mathrm{~mm}$ from the margin, weakly raised on the lower surface; basal veins $3-4$ pairs, the basal rib naked only within $1 \mathrm{~cm}$ of the end nearest the petiole. Inflorescences erect at anthesis, up to 5 per axil; peduncles $14-15 \mathrm{~cm}$ long, 5-8 mm diam. (dried); spathe tube green, 4-5 cm long, ca. $1.3 \mathrm{~cm}$ diam.; spathe blade greenish white, ca. $7 \mathrm{~cm}$ long, $2.2 \mathrm{~cm}$ diam. (unopened), acuminate at the apex, gradually constricted near the base; spadix sessile, white, 7.5-8.5 $\mathrm{cm}$ long; staminate portion of the spadix more or less ellipsoid, $5.5 \mathrm{~cm}$ long, 13 $15 \mathrm{~mm}$ diam., the staminate flowers with the synandrium truncate and obscurely 4-lobed at the apex, the lobes often obscurely emarginate at the apex. Infructescences pendent, yellowish; not seen with mature fruit. Figs. 9, 10, 15, 25.

Distribution: Syngonium hastiferum is known for certain only from Costa Rica, principally in the southeast portion in premontane wet, tropical wet and premontane rain forest life zones. A sterile juvenile collection from Darién Province, Panama, is believed to be this species also but lacks the typically narrow sinus. It is recognized by its entire leaves and relatively small lobes with narrow or often closed sinus and relatively longer lobes which are usually somewhat angular and moderately pointed at the apex. The character of rounded versus angular lobes breaks down to some extent, and plants in Costa Rican populations can be found, e.g., Croat 32919, which have one lobe rounded and one lobe angular.

Syngonium hastiferum is similar to $S$. meridense which has a broad sinus with 

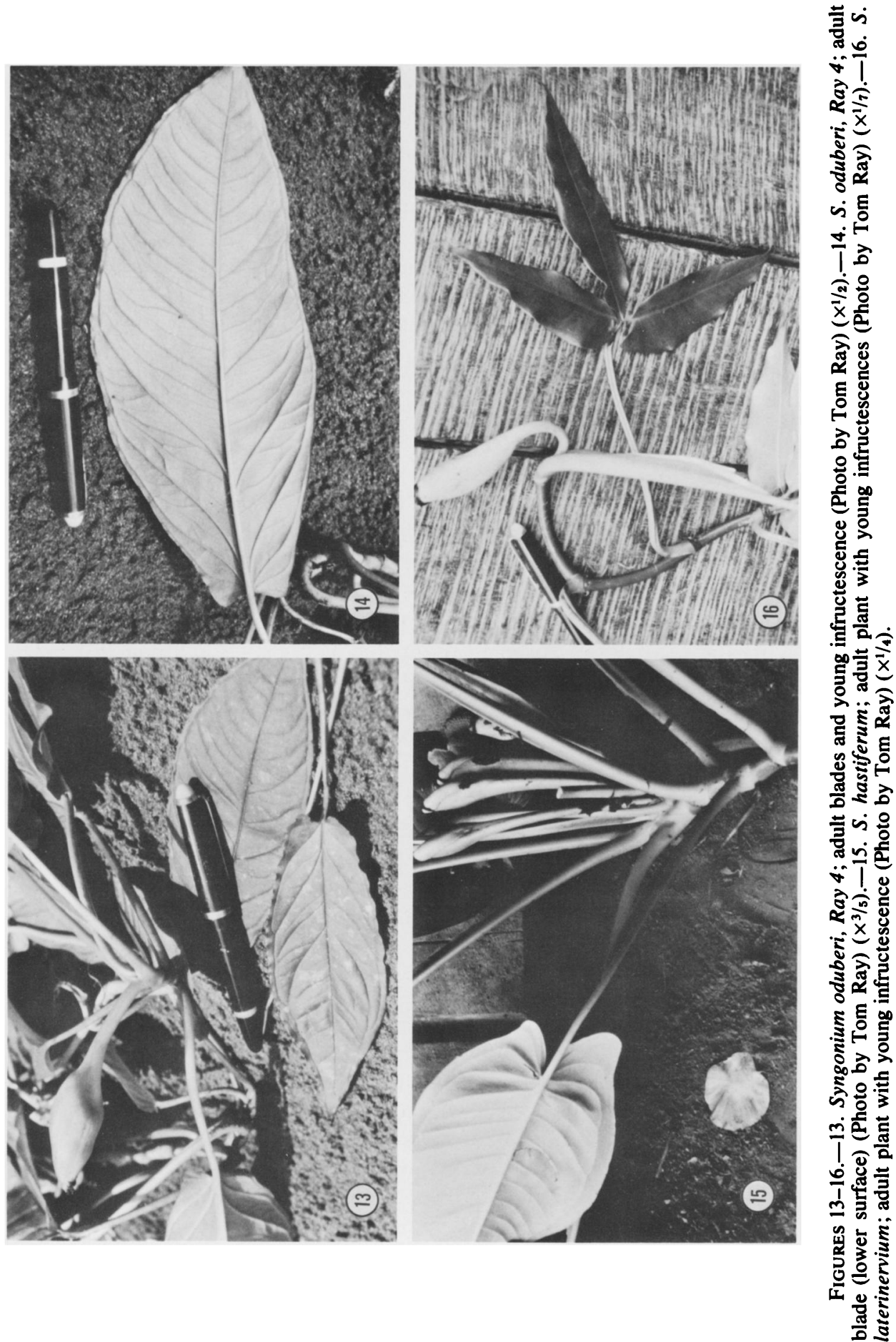
relatively short lobes that are usually rounded. The latter species is restricted to western Venezuela (Mérida). Syngonium hastiferum is also similar to $S$. chocoanum from Chocó of Colombia. That species differs in having an open sinus and a markedly different pattern of venation. In $S$. chocoanum the primary lateral veins have conspicuous branches and the tertiary veins are obscure, close and clearly parallel. In $S$. hastiferum the primary lateral veins have no conspicuous major branches and the tertiary veins are conspicuous, relatively remote from one another, and markedly wavy. In its venation $S$. hastiferum appears similar to $S$. meridense. Syngonium hastiferum is also related to S. sagittatum and S. schottianum but differs from both by its leaf shape and its smaller inflorescences. In leaf texture and color it is closer to $S$. sagittatum.

Fertile flowering collections of $S$. hastiferum have been seen in October. Immature fruits have been seen in April.

Costa Rica: alajuela: NW of Zarcero, Croat 43579 (MO). puntarenas: Between Río Esquinas and Palmar Sur de Osa, Allen 5563 (US); Hills Above Palmar Norte, Croat 35112 (MO); W of Rincón de Osa, Burger \& Stolze 5532 (NY); Between Palmar Sur and Piedras Blancas, Croat 32911 (MO). SAN José: W of San Isidro del General, Croat 32919 (MO); SW of Río Pacuare, Croat 35345 (MO).

10. Syngonium hastifolium Engler, Bot. Jahrb. Syst. 37:41. 1905. TYPE: Brazil, Amazonas, Río Jurua at Fortaleza, Ule 6010 (B, holotype)

Scandent hemiepiphyte; stem thick; petiole ca. $25 \mathrm{~cm}$ long, sheathed more than $3 / 5$ of its length, the sheath free-ending and rounded at the apex; blade entire, acuminate at the apex, conspicuously hastate at the base, 20-25 cm long, the anterior lobe $15-18 \mathrm{~cm}$ long, $7.5-8.5 \mathrm{~cm}$ wide, constricted at the base, ca. $6.5 \mathrm{~cm}$ wide at the constriction, the sides broadly rounded, the posterior lobes slightly unequal, directed outward at ca. $45^{\circ}$ angle, $10-11 \mathrm{~cm}$ long, $4-4.5 \mathrm{~cm}$ wide at their widest point, almost acute at the apex; the primary lateral veins 4-6, per side, joining the midrib at $30-45^{\circ}$ angle; primary collective vein ca. $4 \mathrm{~mm}$ from the margin; posterior rib extending straight to the tip of the posterior lobe. Inflorescences several, erect; prophylls linear-oblong, acute at the apex, 10-15 cm long; peduncles 5-6 cm long; spathe tube oblong, ca. $4 \mathrm{~cm}$ long, ca. $1 \mathrm{~cm}$ diam.; spathe blade ovate-oblong, acute at the apex, 6-7 cm long, ca. $5 \mathrm{~cm}$ wide; pistillate portion of the spadix ca. $1.5 \mathrm{~cm}$ long, ca. $5 \mathrm{~mm}$ diam.; staminate portion of the spadix ca. $5 \mathrm{~cm}$ long, ca. $1 \mathrm{~cm}$ diam. (dried). Infructescences unknown. Fig. 11.

DisTRIBUTION: The species is known only from the type collection.

It is believed to have a close affinity with $S$. podophyllum and may merely represent an unusual, prematurely flowering individual since the leaves are virtually identical to the pre-adult leaves of that species.

The type collection was in flower in October.

For an illustration of this species see Field Museum type photo \#12293.

Brazil: amazonas: Fortaleza, Ule 6010 [B, MO (Photo)].

11. Syngonium meridense Bunting, Acta Bot. Venez. 10:324. 1975. TYPE: Venezuela, Mérida, Caño Blanco (Puente Hierro), carretera Caño Zancudo-La Azulita, Bunting 4381 (MY-002512, holotype; VEN, isotype). 
Epiphytic or hemiepiphytic vine, usually to 2-3 m long. Juvenile plants with stems less than $1 \mathrm{~cm}$ diam., not glaucous; petioles $10-15 \mathrm{~cm}$ long, subterete above the sheath; blades oblong-elliptic, usually broadest in the middle, somewhat inequilateral, subacute to acuminate and apiculate at the apex, narrowed to a weakly lobed base; primary lateral veins 4-5 pairs, sharply ascending to the apex, each forming a distinct collective vein; posterior lobes $10-17 \mathrm{~cm}$ long, narrowly rounded to acutely angular. Adult plants with stems green in the apical portion, usually to $2.5 \mathrm{~cm}$ diam.; internodes $3-4 \mathrm{~cm}$ long; petioles usually $36-47 \mathrm{~cm}$ long, sheathed ca. $2 / 3$ their length, the sheath open, $26-32 \mathrm{~cm}$ long, persistent; blades held in same plane as the petiole, thinly coriaceous, drying chartaceous, simple, suboblong-ovate to triangular-ovate, abruptly acuminate at the apex (the acumen bluntly rounded at the tip with a short apiculum), obliquely cordate at the base, 25-32 cm long, 15-21 cm wide, dark green, matte above, light green, matte below, the posterior lobes broadly rounded or rarely obtusely angular, 6-9 cm long (from the tip to the apex of the sinus), the sinus arcuate with a decurrent petiole; primary lateral veins 5-9 pairs, ascending at $40-45^{\circ}$ angle, each forming a distinct collective vein; tertiary veins very distinct on the lower surface, almost obscure on the upper surface; basal veins 5-6 pairs, free or nearly so to the base. Inflorescences 2 or 3 per axil; peduncles 9-12 cm long, compressed; spathe (juvenile) $12 \mathrm{~cm}$ long; spathe tube fusiform, $2.5 \mathrm{~cm}$ long, $1.3 \mathrm{~cm}$ diam., dark green on the outside, pale green within; spadix (juvenile) $5 \mathrm{~cm}$ shorter than the spathe, subsessile; pistillate portion of the spadix $1.8 \mathrm{~cm}$ long, $9 \mathrm{~mm}$ diam. at the base, 8 $\mathrm{mm}$ diam. at the apex; staminate portion of the spadix somewhat clavate, $5.7 \mathrm{~cm}$ long, $9 \mathrm{~mm}$ diam., narrowed above the sterile staminate flowers (ca. $1 \mathrm{~cm}$ above) to $6.5 \mathrm{~mm}$ diam., the remainder ca. $8.5 \mathrm{~mm}$ diam., obtuse at the apex. Infructescences (immature) $8 \mathrm{~cm}$ long, $2.6 \mathrm{~cm}$ diam., dark green on the outside, pale green within. Figs. 12, 17, 18.

Distribution: Syngonium meridense is endemic to Venezuela and is known only from the state of Mérida.

Syngonium meridense is recognized by its simple leaf blades with short, rounded posterior lobes and basal veins free or nearly free to the base. It is most closely related to $S$. chocoanum from northern Colombia and western Panama. It differs from that species by its broader sinus and in having the tertiary veins distinct and wavy and in lacking any major branches from the primary lateral veins. Syngonium chocoanum has blades noticeably narrowed toward the base with a relatively narrow sinus. The latter species also has many conspicuous branches from the primary lateral veins (at least in the lower $1 / 3$ of the blade), which form an acute angle with the primary lateral veins. The tertiary veins are obscure, close and markedly parallel, not distinct, remote and wavy as in $S$. meridense. It can also be confused in South America with $S$. crassifolium which differs in having larger leaves with longer, more angular lobes and basal veins which are united into a distinct rib (posterior rib).

A specimen with an immature inflorescence was collected in mid-December and a presumably full-sized fruit was collected in early April.

Venezuela: Mérida: El Vigía/San Cristóbal del Táchira, Bunting 2404B (MY, VEN); Caño Zancudo-La Azulita, Bunting 2800, 4381 (MY, VEN). 

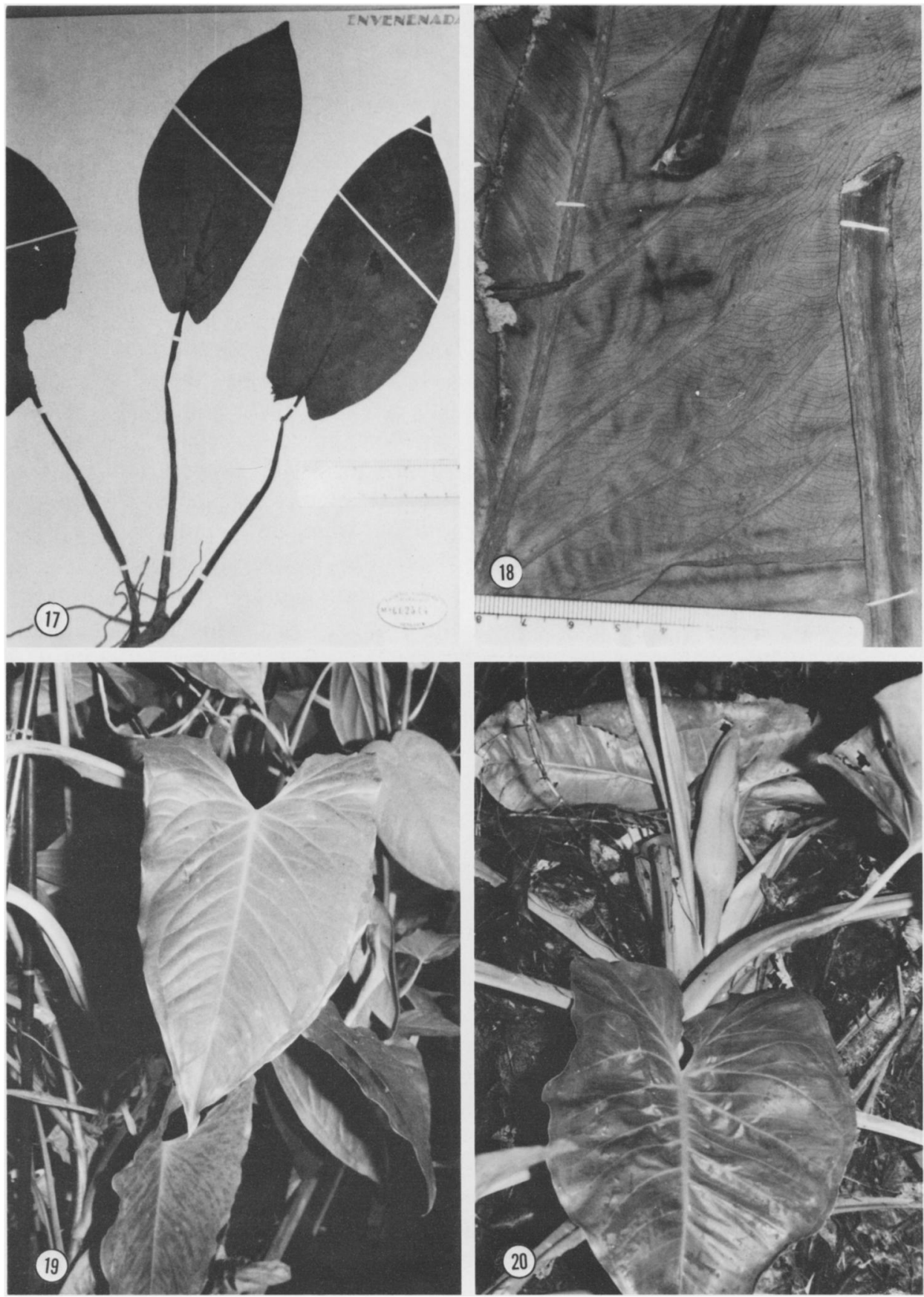

FIGURES 17-20.-17. Syngonium meridense, Bunting 2404B; juvenile leaves.-18. S. meridense, Bunting 4381; lower surface of adult plant showing wavy tertiary veins.-19. S. sagittatum, Croat 48080 ; preadult leaves $\left(\times^{1 / 3}\right) .-20$. S. sagittatum, Croat 48080; adult leaves and unopened inflorescence $\left(x^{1 / 7}\right)$. 
12. Syngonium sagittatum Bunting, Gentes Herb. 9:372. 1965. TYPE: Mexico, Oaxaca, Sierra de Juárez, at Vista Hermosa, 17.9 mi from bridge at Valle Nacional on road to Oaxaca, Moore \& Bunting 8920 (BH, holotype; MEXU, isotype).

Juvenile plants with stems ca. $1 \mathrm{~cm}$ diam., drying weakly verrucose with many slender longitudinal ridges; petioles broadly sheathed ca. $2 / 3$ of their length; blades triangular-elliptic, 19-23 cm long, 7-9 cm wide, the anterior lobe acuminate at the apex, weakly constricted at the base, the posterior lobes narrowly triangular, rounded at the apex. Adult plants with stems to ca. $2 \mathrm{~m}$ long, short-creeping, closely appressed to trees; internodes green, 3-5.5 cm long, longer toward the base of the stem, $2.5-4 \mathrm{~cm}$ wide; petioles $37-43 \mathrm{~cm}$ long, sheathed $2 / 3$ to $3 / 4$ its length, subterete, weakly flattened laterally above the sheath, the sheath open, thin along its margin; blades simple, subcoriaceous, ovate and conspicuously sagittate at the base, acuminate at the apex, 30-50 cm long, 23-31 cm wide, the upper surface semiglossy, light green, subbullate, the lower surface slightly paler, semiglossy, the margins revolute, the posterior lobes directed somewhat upward at an angle to midrib, usually unequal, rhomboid-triangular, obtusely angular at the apex, 12-18 cm long, usually longer than wide, frequently overlapping, the sinus spatulate to rhombic or obovate (clavate to hippocrepiform when pressed flat); primary lateral veins 9-11 pairs, prominently sunken; some interprimary veins prominently sunken; collective vein weakly sunken above, prominently to weakly raised beneath; basal veins $3-7$ pairs, coalescing $1.5-7 \mathrm{~cm}$ from the petiole, the basal rib naked $1-5 \mathrm{~cm}$. Inflorescences 2 or 3 , erect; peduncles ca. 15 $\mathrm{cm}$ long; spathe thick and fleshy, $15-26 \mathrm{~cm}$ long; spathe tube ellipsoid, $8-11 \mathrm{~cm}$ long, 4.5-5 cm diam., greenish outside, tinged with violet purple inside, the constriction usually at a point about midway on the staminate portion of the spadix; spathe blade $14 \mathrm{~cm}$ long, long-acuminate and convolute at the apex (not fully flattened, even at anthesis), greenish white; pistillate portion of the spadix 2-4 $\mathrm{cm}$ long, $1.5-2.2 \mathrm{~cm}$ diam., slightly narrower at the apex, pale green, the synandrium irregularly 4-6-sided, smooth to bumpy at the apex, densely and minutely papillate, $6 \mathrm{~mm}$ long, 2-3 mm diam.; staminate portion of the spadix $10.5-$ $13 \mathrm{~cm}$ long, 2-2.5 cm diam., broadest at about the middle. Infructescences green, pendent, weakly flattened, ca. $7 \mathrm{~cm}$ diam. in broadest view. Figs. 19, 20, 29.

Distribution: Syngonium sagittatum is known for certain only from the Sierra de Juárez in eastern Oaxaca at elevations of 1200-1400 m. The area appears to be tropical wet forest.

The species is apparently most closely related to $S$. crassifolium of Colombia and Ecuador and has nearly identical leaves. It differs from that species in having a long-acuminate spathe. Syngonium crassifolium has a spathe which is acute or merely short-acuminate at the apex. Despite their similarities, it is doubtful that these two species are the same because of their very disjunct ranges and the fact that no other closely related plants have ever been collected between Mexico and Colombia-Ecuador.

Syngonium sagittatum is also related to S. schottianum and S. hastiferum, but of these two species it is most similar to the former, with which it shares a similar leaf shape and inflorescence. It differs from $S$. schottianum principally in 

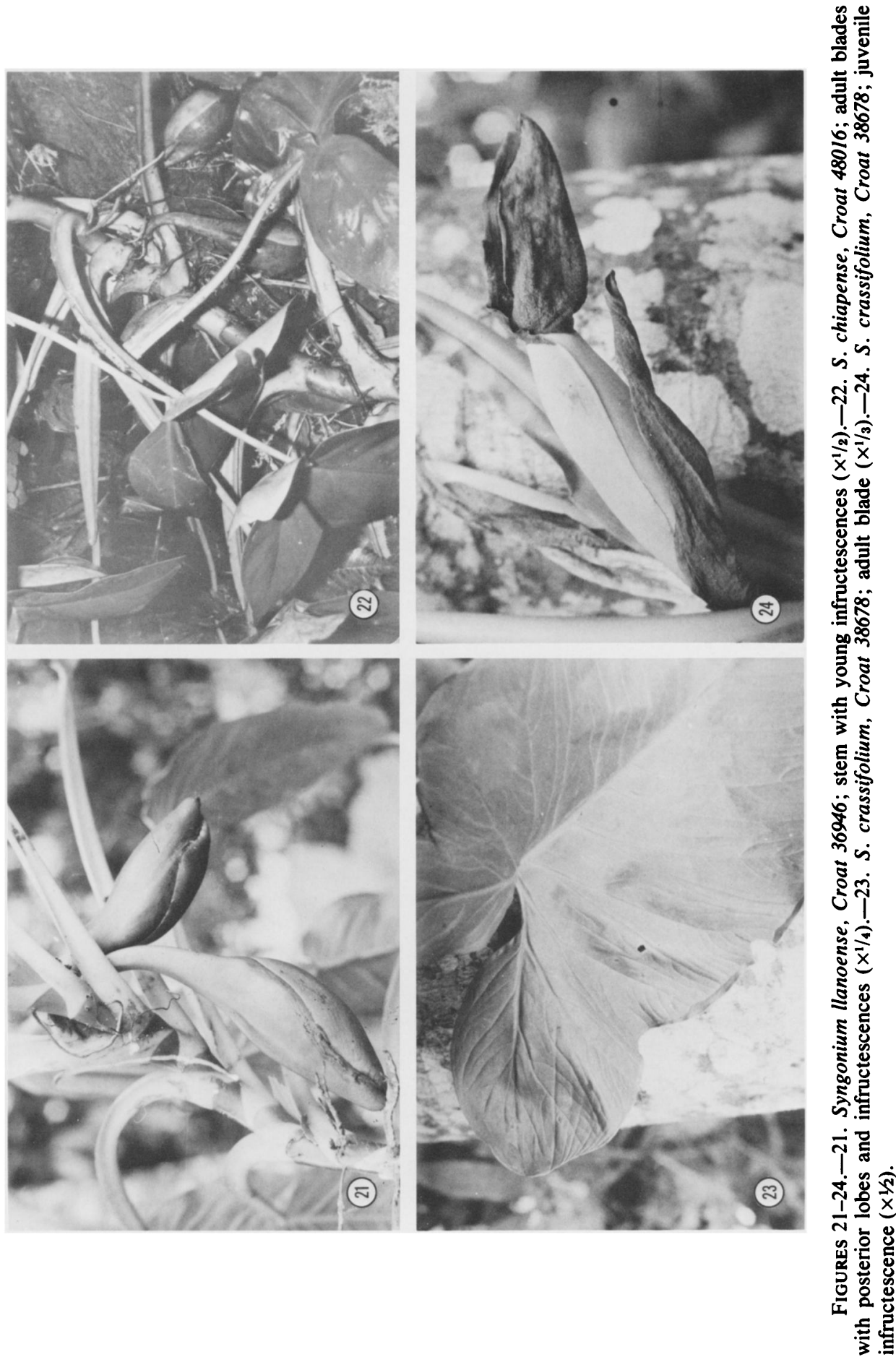
having a thinner blade which dries green rather than typically whitish as in $S$. schottianum.

The species is probably the same as $S$. xanthosomaphyllum, which was proposed as a new species by Birdsey (1955). However, the collection (Birdsey 300) from near Jalapa, Veracruz, has never been located. Syngonium sagittatum would certainly be expected to occur there and it is expected to be the same.

It has been collected in flower in February and September and in mature fruit in February.

Mexico: oAXaca: Sierra de Juárez, Bunting 1657 (BH, MEXU), Croat 48004 (MO), 48080 (F, MEXU, MO, NY, SEL), Moore \& Bunting 8920 (BH, US).

13. Syngonium schottianum Wendl. ex Schott, Prodr. 200. 1860. TYPE: Costa Rica, Wendland (destroyed, type photo seen FM-12301).

Porphyrospatha schottiana (Wendl. ex Schott) Engler in A. DC., Monogr. Phan. 2:290. 1879.

Juvenile plants with scandent stems; internodes $10-20 \mathrm{~cm}$ or more, to ca. 1 $\mathrm{cm}$ diam., petioles sheathed beyond the middle, often to near the apex; blades ovate, becoming ovate-elliptic, with small lobes at base, the lobes rounded or angulate; venation conspicuous, the primary lateral veins sunken above, the tertiary veins clearly visible beneath. Adult plants epiphytic or hemiepiphytic creepers; stems to ca. $1 \mathrm{~m}$ long, ca. $4 \mathrm{~cm}$ wide; internodes very short; petioles $47-100$ $\mathrm{cm}$ long, prominently sheathed except for the distal 5-13 cm, subterete above the sheath, weakly flattened near the blade attachment, the sheath firm, to $3 \mathrm{~cm}$ high near the base, tapering to $1 \mathrm{~cm}$ at the apex, with one margin shorter, the apex free, round, boat-shaped; blades lobed at the base, 40-60 cm long, 19-37 cm wide, dull on both surfaces, medium green above, much paler beneath, whitish, the posterior lobes directed slightly upwards and sometimes closing the sinus, sometimes slightly unequal, the sinus 6-14 cm deep, usually narrow, sometimes as broad as deep; basal portions of the major lateral veins sunken, the collective veins weakly visible, all other veins obscure on the upper surface; lower surface with the basal portions of the major lateral veins raised, arcuate-ascending and loop-connected with the major laterals, forming weak collecting veins, the innermost arising from the middle or lower $1 / 3$ of the blade, the successive collective veins closely paralleling the first but becoming closer and more obscure toward the margin, spaced at intervals of $0.5-3 \mathrm{~mm}$, each arising from the lower primary lateral veins and basal veins; basal veins $2-4$, coalescing up to $1-4 \mathrm{~cm}$ from the petiole, the basal rib naked $1-6 \mathrm{~cm}$. Inflorescences 4 per axil, each subtended by a prophyll ca. $25 \mathrm{~cm}$ long, $4 \mathrm{~cm}$ wide, conspicuously 2-ribbed on the outside surface, the ribs thin, ca. $4 \mathrm{~mm}$ high; peduncles $15-20 \mathrm{~cm}$ long, obtusely 3-sided; spathe tube green or green tinged with purple mostly in longitudinal streaks, pale violet purple inside, ca. 9-10 cm long at anthesis (to $17 \mathrm{~cm}$ long and $7.5 \mathrm{~cm}$ diam. in fruit); spathe blade whitish, ca. $10 \mathrm{~cm}$ long, constricted at its base and articulating along an elevated ring which forms $4-5 \mathrm{~cm}$ above the apex of the pistillate part of the spadix; spadix to $19.5 \mathrm{~cm}$ long; staminate portion of the spadix $19 \mathrm{~cm}$ long, $3 \mathrm{~cm}$ diam., white; pistillate portion of the spadix pale orange, $3.5 \mathrm{~cm}$ long on the open side, to $2.5 \mathrm{~cm}$ long on the back side, the stigmas bright yellow, irregularly rounded, $3.5 \mathrm{~mm}$ diam., ca. $1 \mathrm{~mm}$ high, with an irregular, often slitlike 

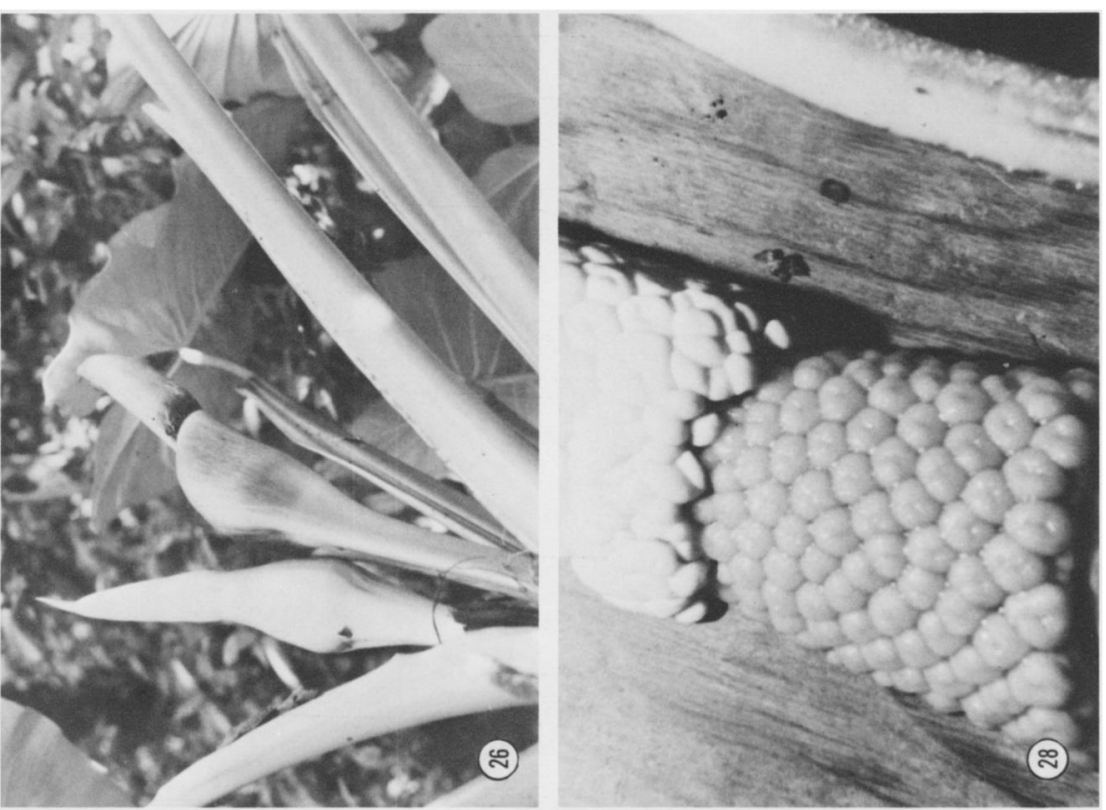

这这

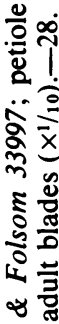

ธิ่

รี ธุด

s.

:

ఫه

ธิ ఫే

vi心

จं हे

1 운

i.

齐产

政

进的

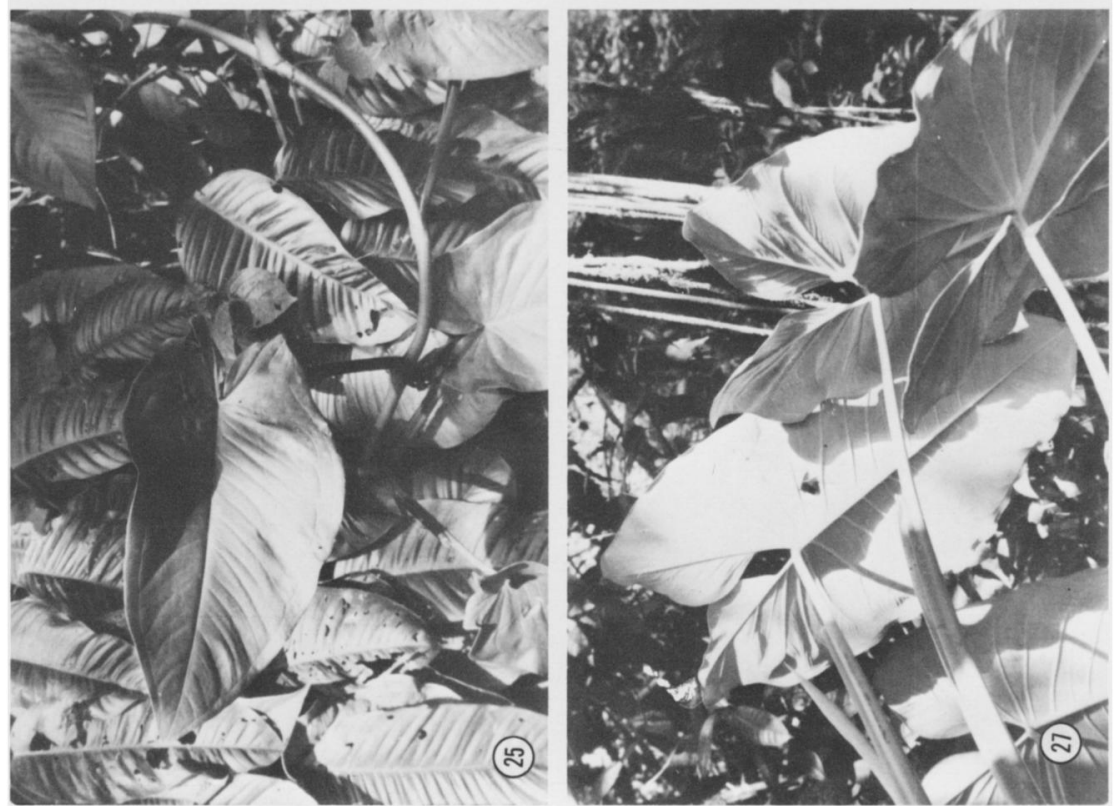

흥.

बंग

产芒

$\ddot{\alpha} \underline{x}$

西要

m

安

20 o

$0 \geq \frac{5}{3}$

ह ํํㄹ

sis

范

ปั่

इ

콣 은

5.

so

के

๘

iั

1 年

i்

$\approx \mathscr{D}_{0} \&$

กิ

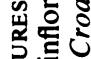

跑

吾 
depression in the center. Infructescences usually green, heavily tinged with purple, 14-16 cm long, 5-6 cm wide; fruiting spadix 7.5-10 cm long on the open side, $6-7 \mathrm{~cm}$ long on the back side, $3-5.5 \mathrm{~cm}$ diam., the surface pale brown; stigmas raised, ca. $2.8 \mathrm{~mm}$ wide, the central core ca. $1 \mathrm{~cm}$ diam.; seeds irregularly oblong, white, ca. $7 \mathrm{~mm}$ long. Figs. 26-28, 30.

DisTRIBUTION: Syngonium schottianum ranges from Honduras to Panama but is also likely to range into Colombia. The species has been collected in Costa Rica only on the Atlantic slope in Alajuela and Heredia. It is restricted to the Atlantic slope except at middle elevations along the Continental Divide in central Panama. It ranges from near sea level to about $900 \mathrm{~m}$ in wetter parts of tropical moist forest, premontane wet forest, and tropical wet forest.

See the discussion of $S$. sagittatum for possible relationships with that species. The species is closest to $S$. crassifolium from Colombia and Ecuador, but it differs from that species by its pale lower blade surface and its generally larger inflorescences.

Flowering inflorescences have been found from February through August. Nearly mature fruits are known from July.

Costa Rica: alajuela: NE of Quesada, Croat 46950 (MO); Near Upala, Croat 36261, 36445 (MO). CARTAgo: NE of Turrialba, Croat 43367 (MO). Heredia: Near Puerto Viejo, Croat 35686, 35759 (MO). LIMón: S of Punta Cahuita, Croat 43190, 43196 (MO).

Honduras: olancho: N of Catacamas, Standley 18745 (F).

NiCARAGUA: Río SAN JUAN: NE of El Castillo, Neill \& Vincelli 3617 (MO). ZELAYA: Vicinity of Matagalpa, Stevens 7516 (MO).

PANAMA: bocAS DEL TORO: W of Almirante, Croat 38210 (MO); Station Milla 7.5, Croat 38114 (MO). CHIRIQUí: Vicinity of Fortuna Dam site, Croat 48710 (MO). coclé: Vicinity of El Copé, Hammel 2632 (MO), Croat 49148 (MO); La Mesa, Croat 13421, 37406 (MO); Cerro Pilón, Lallathin 5004 (MO), Croat 14363 (MO); N of Cerro Pilón, Croat 37568 (MO), colón: Vicinity Guásimo, Croat 9959 (MO), 9935 (MO, SCZ); Near Portobelo, Kennedy 480 (F), Croat 36972 (MO). PANAMÁ: NE of Alto de Pacora, Croat 22730 (MO); Cerro Campana, Croat 17244, 25223, 35984 (MO). VERAGUAS: Escuela Agrícola Alto Piedra, Croat 25542, 27339, 48974 (MO), Croat \& Folsom 33997 (MO); Near Santa Fe, Croat 33991 A (MO).

C. Syngonium section Pinnatilobum Croat, sect. nov. TYPE SPECIES: Syngonium steyermarkii Croat.

Lamina adulta profunde lobata incisa; petiolus vaginatus ad medium usque; lamina juvenalis simplex, ovata, basi cordata; lamina intermedia incisa magis.

14. Syngonium steyermarkii Croat, sp. nov. TYPE: Guatemala, San Marcos, vicinity of San Rafael, Finca Armenia at La Trinidad, ca. $2 \mathrm{~km}$ above main buildings of finca, 1100-1250 m, virgin forest along stream, Croat 40842 (MO2599645, holotype; EAP, F, MEXU, PMA, US, USCG, VEN, isotypes).

Caudex haud glaucus, scandens, internodiis $2-4 \mathrm{~cm}$ longis, $1-3 \mathrm{~cm}$ latis; foliorum petiolus $25-60$ $\mathrm{cm}$ longus, ca. ad $1 / 2$ longitudinalis usque vaginatus; lamina incisus lobo, ambito ovata, $20-43 \mathrm{~cm}$ longa, $17-36 \mathrm{~cm}$ lata, lobus anticus segmentis 5-6, 2-5 cm latis. Inflorescentia in axilla 1-7, pedunculus $7-13 \mathrm{~cm}$ longus; spathae tubus $2.6 \mathrm{~cm}$ longus, $2 \mathrm{~cm}$ latus; pedunculus et spathae tubus valde glaucus.

Hemiepiphytic creeper; sap milky; stems 1-3 cm diam., $1.3 \mathrm{~m}$ long; upper internodes $1.5-2.5 \mathrm{~cm}$ long, dark green, shiny, drying light brown, shiny, the periderm drying wrinkled; leaves ca. 8, persisting only near the apex, broadly spreading; petioles $25-60 \mathrm{~cm}$ long, subterete, sheathed to beyond the middle to upper $2 / 3$, sharply ribbed near the apex of the sheath, drying black; blades incised- 
lobate, ovate in outline, $20-43 \mathrm{~cm}$ long, $17-36 \mathrm{~cm}$ wide, firmly membranous, medium green above, paler beneath, drying black, the anterior lobe with 5 or 6 segments, shallowly lobed to within $1-2 \mathrm{~cm}$ distant from the midrib, the segments $2-5 \mathrm{~cm}$ wide, narrowly rounded at the apex, the posterior lobes about half as long as the anterior lobe, the segments partly confluent; midrib and primary lateral veins sunken above, raised and U-shaped beneath; secondary veins and collective vein weakly sunken on the upper surface, weakly raised on the lower surface; tertiary veins distinctly visible. Inflorescences 1-7 per axil; peduncles terete, erect in flower, 7-13 cm long, ca. $1 \mathrm{~cm}$ diam., straight to sigmoid; spathes 5.5$7 \mathrm{~cm}$ long, somewhat fleshy, narrowly ovoid, acuminate, tightly inrolled and curved forward at the apex, scarcely constricted near the middle, opening from the apex of the spadix to the base of the spadix; spathe tube green, glaucous, grayish or whitish green, ca. $2.6 \mathrm{~cm}$ long, $2 \mathrm{~cm}$ diam.; spathe blade green, scarcely or not at all flared open; spadix $5-5.5 \mathrm{~cm}$ long; pistillate portion of the spadix 2.6$3 \mathrm{~cm}$ long, $2 \mathrm{~cm}$ diam., broader than the staminate portion, the pistillate flowers pale green, 4-5 $\mathrm{mm}$ diam., the stigma sessile, ca. $2 \mathrm{~mm}$ diam., orange yellow; staminate portion of the spadix $2-2.5 \mathrm{~cm}$ long, $0.6-1.3 \mathrm{~cm}$ diam., the staminate flowers creamy white, the synandrium truncate at the apex with a medial depression, irregularly 4-6 sided, 2-3 mm diam. Infructescences with the spathe tube 6-7 cm long, 3.5-4 cm diam., in part weakly glaucous, obtusely ribbed on the closed side; fruiting spadix 5-7 cm long, ca. $4 \mathrm{~cm}$ diam. Figs. 31, 37-39.

Distribution: Syngonium steyermarkii is known only from the Pacific slope of Guatemala and southeastern Mexico at elevations above $1250 \mathrm{~m}$.

The species is named in honor of Julian A. Steyermark who made three collections of it between 1940 and 1942 in three different departments of Guatemala.

Syngonium steyermarkii is unique in having incised-lobate leaves like those of Philodendron radiatum Schott. It also differs from other Syngonium species in having the inflorescences all mature at about the same time and having the pistillate part of the spadix appreciably larger than the staminate portion.

The data on the flowers was provided by Josef Bogner from a living collection of, Croat 47201 growing at Munich.

The type collection had immature fruits in July.

Guatemala: quezaltenango: Between Finca Pirineos and Patzulín, Standley 86886, 86900 (F); Along Quebrada Geronimo, Finca Pirineos, S slope of Volcán Santa María, 1300-2000 m, Steyermark 53437 (F). SAN MARCos: Finca El Porvenir along Río Chopal, S slope of Volcán Tajumulco, 1300-1500 m, Steyermark 37499 (F); Above San Raphael, Croat 40842 (MO). suchITEPIQUEZ: Volcán Santa Clara between Finca El Naranjo and upper slopes, 1250-2650 m, Steyermark 46621 (F).

Mexico: Chiapas: N of Puente Monte Perla, Croat 47201 (MICH, MO).

D. Syngonium section Syngonium Croat, sect. nov. TYPE SPECIES: Syngonium auritum (L.) Schott.

Lamina adulta trisecta aut 5-11-pedatisecta; segmenta lateralia valde inaequilateralia; petiolus e $1 / 3$ ad $4 / 5$ longitudinis usque vaginatus; lamina juvenalis ovata aut elliptica; lamina intermedia sagittata aut hastata.

15. Syngonium angustatum Schott, Oesterr. Bot. Z. 8:175. 1858. TYPE: Nicaragua, Chontales, Punta Poderoso, Oersted (C). 
S. oerstedianum Schott, Oesterr. Bot. Z. 8:178. 1858. TYPE: Costa Rica, Guanacaste, Oersted (c, not seen); Schott drawing 3214 (NYBG photo 4332).

S. albolineatum hort., H. G., Bull's Catalogue p. 6. 1871. LectotyPE: N. E. Brown, Feb. $27,1877$.

(Specimen from the type plant of Hort. Bull) (K).

S. podophyllum Schott var. albolineatum (Hort.) Engler, Pflanzenr. IV.23E (Heft 71):129. 1920.

S. podophyllum var. oerstedianum (Schott) Engler, Pflanzenr. IV.23E (Heft 71):129. 1920.

Nepthytis triphylla hort. Nash ex L. H. Bailey, in Cycl. Amer. Hort. 3:1076. 1901. TYPE: (not seen, fide Birdsey, 1955).

Syngonium gracilis Matuda, Anales Inst. Biol. Univ. Nac. Mexico 43, Ser. Bot. 1:56-57. 1972, non (Miq.) Schott. TYPE: Mexico, Oaxaca, Palomares, Juchitán, near Río Coatzacoalcos, $200 \mathrm{~m}$, MacDougall 804-4 (MEXU, holotype).

Juvenile plants with stems not glaucous, usually sparsely muricate; petioles sheathed usually less than $1 / 3$ their length; blades dark green, marked on the upper surface along the principal veins with gray green, cordate, less than $6 \mathrm{~cm}$ long, the anterior lobe ovate, the posterior lobes suborbicular; intermediate leaves sagittate or hastate, acuminate at the apex. Adult stems not glaucous, sparsely muricate; internodes mostly $2-10 \mathrm{~cm}$ long on the flowering stems; petioles sometimes pruinose, sheathed $1 / 2-4 / 5$ their length, $15-40 \mathrm{~cm}$ long; blades pedatisect, dark green above, sometimes grayish green on the midrib and rarely on the lateral veins; leaflets $3-11$, usually conspicuously free from one another, the lowermost auriculate, the median leaflet elliptic to oblong-elliptic to oblanceolate, acuminate at the apex, attenuate, acute or cuneate at the base, $11-31 \mathrm{~cm}$ long, 4-10 cm wide, the rachis gradually curved, the lateral leaflets inequilateral, the inner margin acute to cuneate, the outer margin rounded to auriculate, the auricle rounded to bluntly acute, rarely slightly pinched off; primary lateral veins 3-5 pairs, sunken above, raised beneath; tertiary veins distinct. Inflorescences to ca. 7 per axil; peduncles glaucous, almost 3-sided, $5-10 \mathrm{~cm}$ long, and erect at anthesis, to 17 $\mathrm{cm}$ long and pendent in fruit; spathe 7 to $14 \mathrm{~cm}$ long; spathe tube elliptic, $2-5 \mathrm{~cm}$ long, 1.0-2.5 cm diam., green and usually glaucous outside, green inside; spathe blade cream on both surfaces, 6-9 $\mathrm{cm}$ long, 1.5-3.5 $\mathrm{cm}$ wide, acuminate at the apex; pistillate portion of the spadix 1.3-2.6 cm long, 5-10 $\mathrm{mm}$ diam., greenish, the flowers irregularly hexagonal, the stigma discoid; staminate portion 2.5-6.5 $\mathrm{cm}$ long, 5-15 mm diam., pale yellow, the flowers completely fused into a synandrium with no sign of fusion, the apex conspicuously retuse. Infructescences usually bright red, sometimes reddish orange, sometimes glaucous; fruiting spadix brown, 2.5-4.5 cm long, $1.5-2.5 \mathrm{~cm}$ diam. Figs. 32, 40, 45.

DisTribution: Syngonium angustatum ranges from Mexico (southern Tamaulipas) through Belize, Guatemala, Honduras and Nicaragua to northern Costa Rica. It is cultivated in Panama. Although most abundant at lower elevations, it ranges up to $700 \mathrm{~m}$ (to $1000 \mathrm{~m}$, fide Birdsey, 1955). The species is most abundant in tropical moist forest life zones, but has been collected in tropical dry forest in Nicaragua and Costa Rica.

Syngonium angustatum is closest to $S$. podophyllum but can usually be distinguished by its more uniformly slender leaflets, the papillae of the older stems, and the deeply retuse, fused staminate flowers (also see the key). According to Birdsey (1955) the species hybridizes with $S$. podophyllum in Mexico.

Syngonium angustatum apparently flowers most abundantly during the early rainy season with some flowering during the dry season as well. 

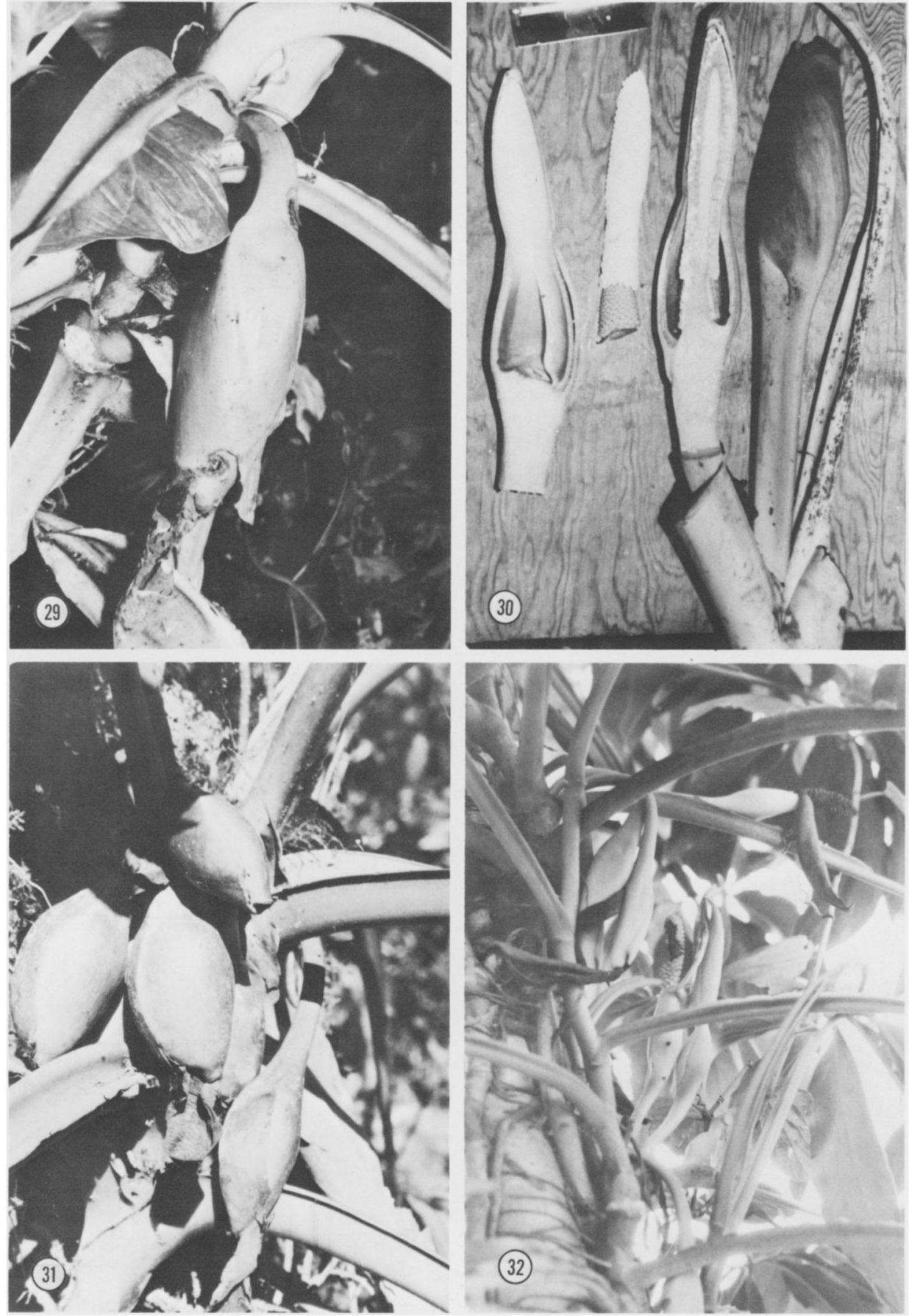

Figures 29-32.-29. Syngonium sagittatum, Croat 48080; stem and infructescence $\left(\times^{1 / 4}\right) .-30$. S. schottianum, Croat \& Folsom 33997; longitudinal section of inflorescence showing half of spathe (left) and half of spadix (right) removed $\left(\times^{1 / 4}\right)$. - 31. S. steyermarkii, Croat 40842 ; stem and infructescences $\left(\times^{5 / 12}\right) .-32$. S. angustatum, Croat 41699; stem, inflorescences (erect, young infructescences pendent) $\left(\times^{1 / 4}\right)$. 
BAHAMAS: Eleuthera, Correll 49000 (NY).

Belize: Maskall Pine Ridge, Gentle 1144 (F, G, MICH, NY). BElize: Northern Highway, Dwyer \& Liesner. 12043 (GH, MO, NY); SW of Belize, O'Neill 8257, 8542 (MICH). CAYO: S of Grano de Oro, Croat 23403 (F, MO), 23781 (MO), Dwyer 10890 (MO); Roaring Creek, Wiley 246 (MO); Near Augustine, Spellman 1584 (MO). corozal: Between Corozal and Pachacen, Gentile 62 (F), Lundell 4935 (F, NY); No other location, Gentle 459, 616, 502 (MICH). STANN CREEK: W of Stann Creek, Croat 24205 (MO). Toledo: N of Columbia Forest Station, Croat 24232 (MO); Punta Gorda, Croat 24469 (F, MO); Temash River, Dwyer 12885, (MO).

Colombia: Island of Providencia, Proctor 3476 (US).

Costa Rica: Alajuela: Vicinity of Los Chiles, Holm \& Iltis 812 (A). guanacaste: S of Peñas Blancas, Liesner 4658 (MO).

Guatemala: alta Verapaz: Eastern portions, Watson \& Sereno 104 (GH); E of Panzos, Croat 41699 (MO). IZABAL: SW of Puerto Barrios, Croat 41836 (MO), Standley 72127, 72565 (F). PETÉN: Uaxactún, Bartlett 12664 (MICH, US); La Libertad, Lundell 2432 (MEXU, MICH), 2544 (GH), 3213 (F); National Park of Tikal, Ortiz 333 (F). ZACAPA: N from Route CA9, Croat 41882 (MO).

Honduras: COLón: W of Trujillo, Murry 449 (MO); Vicinity of Cuidad de Castilla, Nelson \& Martínez 1191 (TEFH). CORTES: SW of Omoa, Croat 42559 (MO); Road to Chamelecón Cafradia, Molina 3849 (GH, F); SW of Puerto Cortés, Nelson et al. 3020 (TEFH). GRACIAS A DIOs: Mosquitia, Clewell \& Cruz 4050 (GH, MO); Puerto Lempira, Nelson 4846 (TEFH). olancho: Dulce Nombre de Culmí, Nelson \& Clewell 438 (MO, TEFH).

Mexico: No other location, Sandoval 6 (US). CAMPEche: Tuxpeña, Lundell 815 (F, MICH, US). CHIAPAS: Vicinity of Palenque, Croat 40137, 40315 (MO), Matuda 3825 (GH, MICH, MEXU). OAXACA: N of Matias Romero, R. M. King 841 (MICH, US); Palomares, MacDougall 804A (MEXU); Tuxtepec, Sousa 1859 (MEXU). PUEBLA: Forest of Ajeujihe, D. R. Canta 520 (MEXU). SAN LUIS POTosí: Tamazunchale, M. T. Edwards 581 (MO). TABASco: Villahermosa, Bunting 1652 (BH, MO), Spellman et al. 115 (MO). veracruz: San Andrés Tuxtla, Dressler \& Jones 16 (GH); Vicinity Juan Rodríguez Clara, Gómez-Pompa \& Valdés 1727 (MO); Vicinity Sayula San Juan Evangelista, Leija \& Garza 8137 (MEXU); Tampico, Nevling \& Gómez-Pompa 426 (MEXU); Vicinity Camp Hnos, Valdiva 1184 (JALAPA, MEXU). YUCATÁN: Chichen Itza, Steer 1629 (MICH); Izamal, Greenman $452(\mathrm{~F})$.

Netherlands Antilles: Bonaire, Arnoldo 2296 (US).

Nicaragua: BoACA: N of Río Las Cañas, Stevens 5848 (MO); Vicinity Río Quilan Bridge, Stevens 9323 (MO). CARAzo: Near Jinotepe, Standley 8576 (F). CHONTALES: La Libertad, Standley 8904 (F), Stevens 4091, 4092,4204 (MO); Road to Cuapa, Stevens 3654, 6470 (MO). GRANADA: Volcán Mobacho, Atwood \& Neill AN90 (MO). MANAGUA: Vicinity of National School of Agriculture, Seymour \& Atwood 2228 (MO); Tipitapa, Atwood \& Seymour 3424 (GH, NY, UC), Croat 39051 (MO), Garnier 774 (US), Neill 7260 (MO), Stevens 9509 (MO). MATAGAlPA: Summit of El Toma Road, Neill 1572 (MO); Between La Danta and La Luna, Stevens 9573 (MO). NuEVA SEgovia: N of Jalapa, Neill 1608 (MO). RIVAS: Isla de Ometepe, Stevens 6640 (MO). ZELAYA: Near Bluefields, Hamblett 613 (MO); SE of Cerro San Isidro, Proctor, Jones \& Facey 27048 (NY); Along Caño Majagua, Stevens 6983 (MO); Vicinity of San José del Hormiguero, Stevens 7006, 7047 (MO); Near Tala Has and Puente Mango, Stevens 7639 (MO); SW of Río Wawa, Stevens 7924 (MO). (MO)

Panama: CANal zone: Stevens Circle, Balboa, Croat 9181 (MO); Summit Gardens, Croat 17059

ThaIland: BANGKoK: Cultivated at Kasetsart University Nursery, Nicolson 1691 (B).

16. Syngonium atrovirens Bunting, Acta Bot. Venez. 11:323. 1975. TYPE: Venezuela, Zulia, Hacienda Raizado (Hda. San Benito), ca. $1 \mathrm{~km} \mathrm{~S}$ of Concha, Bunting 2776 (MY-0254, holotype; VEN, isotype).

S. apurense Bunting, Acta Bot. Venez. 11: 322. 1975. TYPE: Venezuela, Apure, Reserva Forestal San Camilo, $7 \mathrm{~km}$ E of La Ceiba, $16 \mathrm{~km} \mathrm{E}$ of El Jordan, $200 \mathrm{~m}$, Steyermark, Bunting \& Blanco 101942 (MY, VEN).

Scandent hemiepiphytes. Juvenile plants with petioles sharply sulcate, the margins narrowly winged; blades dark green, glossy above, pale beneath. Adult plants with stems $1.3-1.5 \mathrm{~cm}$ diam., gray glaucous when young, the epidermis brown and cracked in age; lower internodes $6-9 \mathrm{~cm}$ long, the upper internodes $2-4 \mathrm{~cm}$ long; petioles $25-35 \mathrm{~cm}$ long, gray glaucous, sheathed except for the upper 5-9 cm, the sheath inrolled, sometimes with elevated whitish striations, 
the unsheathed part sharply angular-winged adaxially, the lateral margins sharp, narrowly winged; blades trisect, thin to subcoriaceous, 20-25 cm long, dark green and often glaucescent above, paler green beneath, semiglossy; leaflets usually markedly free and petiolulate rarely confluent, the petiolules $5-15 \mathrm{~cm}$ long, rarely sessile; median leaflet elliptic to elliptic-ovate or oblong-elliptic, acuminate at the apex, obtuse to acute and attenuate at the base, 17-30 cm long, 5-11 cm wide, the primary lateral veins 4-5(-9) per side, weakly sunken, arising at an angle of $(65-) 70-80^{\circ}\left(-90^{\circ}\right)$, weakly curved to the collective vein, the tertiary veins distinct, the primary collective vein $2-6 \mathrm{~mm}$ from the margin, generally more or less straight, the margins sometimes finely undulate; lateral leaflets acute to narrowly rounded at the apex, slightly shorter than the median leaflet, the inner margin cuneate-acute, the outer margin prominently auriculate, the auricles acute to narrowly rounded at the apex, rarely broadly rounded with the auricles overlapping on the blade whose leaflets are not fully free, the primary lateral veins arising at a generally sharper angle than those of the median leaflets (ca. 50-60 ). Inflorescences solitary; peduncles gray glaucous, 5-7 cm long, 6-9 mm diam. at anthesis, soon recurved; spathe 11-15.5 cm long; spathe tube narrowly oblongovoid, $5.5-7.2 \mathrm{~cm}$ long, $1.5-3.5 \mathrm{~cm}$ diam., not markedly constricted below the blade, semiglossy, light green on the outside, paler green within; spathe blade boat shaped when open, obtuse at the apex, cream colored on the outside, creamy white within, weakly tinged with pink toward the base; spadix sessile, $11 \mathrm{~cm}$ long, ca. $3 \mathrm{~cm}$ shorter than the spathe; pistillate portion of the spadix $1.6 \mathrm{~cm}$ long, $1.5 \mathrm{~cm}$ diam. ( $7 \mathrm{~mm}$ on drying); staminate portion of the spadix $8.5 \mathrm{~cm}$ long (dried), the sterile staminate portion $1.2-2.5 \mathrm{~cm}$ long, constricted weakly beneath the fertile part of the spadix. Infructescences pendent, $8-9 \mathrm{~cm}$ long, $2.5 \mathrm{~cm}$ diam. (dried); syncarp ovoid-elliptic, only slightly shorter than the fruiting spathe. Figs. 33, 34.

Distribution: Syngonium atrovirens is known for certain only from Venezuela and has been collected at elevations of 50-500 $\mathrm{m}$ in the states of Apure, Táchira, Mérida, and Zulia. A sterile collection by André (419) from the Magdalena River Valley of Colombia (Naranjo-Carare) is probably also this species.

The species is closely related to $S$. yurimaguense from the upper Amazonian forests of Peru and Bolivia but differs from that species by its inflorescence which is much less constricted above the spathe tube. Both species have in common very similar leaves which have the primary lateral veins of the median leaflet arising from the midrib at almost a $90^{\circ}$ angle.

Venezuela: APURE: East of Ceiba, Steyermark et al. 101942 (MY, VEN); SE of Caserio San Camilo, Steyermark et al. 101478 (VEN). MÉRIDA: SE of El Vigía and El Quince, Bunting 2404A (MO, MY, VEN). TÁchIRA: La Fria-La Grita at Las Pavas, Bunting 2494 (MY, VEN). zULIA: S of Concha, Bunting 2776 (MY, VEN); Sierra de Perijá, Steyermark \& Fernández 99633 (NY, US, VEN).

17. Syngonium auritum (L.) Schott, Wiener Z. Kunst 3:780. 1829.

Arum auritum L., Sp. Pl. ed. 2, 1371. 1763. TYPE: Species No. 1079-17 in Linnaean Herbarium (LINN).

Caladium auritum Vent. ex Willd., Spec. Pl., ed. 4, 4 (Part 1):491. 1805. TYPE: Jamaica? (not seen). Syngonium plumieri Schott, Prodr. Syst. Aroid. 206. 1860. TYPE: Santo Domingo, Plumier (not seen).

Juvenile plants with stems scandent; blades ovate, acute at the apex, sagittate to hastate at the base. Adult stems hemiepiphytic, somewhat scandent, slightly 
glaucous, 1.5-2 cm diam.; internodes 4-9 cm long, with one large feeding root and several clasping roots per node (fide Birdsey, 1955); petioles $15-48 \mathrm{~cm}$ long, broadly sheathed usually $4 / 5$ their length (rarely to $2 / 3$ ); blades usually trisect or sub-5-pedatisect, rarely 5 pedatisect, the lobes confluent, the median lobe 10-30 cm long, 6-20 cm wide, broadly elliptic, abruptly acuminate at the apex, the base obtuse, the tissue continuous with the lateral lobes, the first pair of lateral lobes ovate to elliptic, 6-21 cm long, 3-11 cm wide, acute at the apex, strongly inequilateral, usually conspicuously auriculate on the outer side at the base, the auricle sometimes free, then $4-10 \mathrm{~cm}$ long, to ca. $4 \mathrm{~cm}$ wide, the upper surface semiglossy, medium green, the lower surface paler; primary lateral veins mostly 5-7 pairs, joining the midrib at a $20-45^{\circ}$ angle. Inflorescences to 3 per axil; peduncle $7-13 \mathrm{~cm}$ long; spathe tube cylindroid, $4.2-8.5 \mathrm{~cm}$ long, $1-1.9 \mathrm{~cm}$ diam., dark green outside, green inside with a suffusion of bronzy red at the base; spathe blade ovate in outline when opened, mucronate at the apex, conspicuously constricted at the base, 12-18 cm long, 7-10 cm wide (flattened), creamy white on both sides, sometimes greenish white on the outside and creamy white tinged faintly with violet purple within; spadix extending to $1 / 2$ as high as the spathe blade; pistillate portion of the spadix $3.4-4.8 \mathrm{~cm}$ long, 9-12 mm diam., the flowers mostly rhombic to 5- or 6-sided, the stigma discoid, dark yellowish green (fide Birdsey, 1955); staminate portion of the spadix $3.5-9.2 \mathrm{~cm}$ long, rounded at the apex, slightly attenuate toward the apex, the sterile staminate section 7-17 mm long, creamy white, oblong, slightly attenuate at the apex, the sterile staminate flowers larger and more irregular than the fertile staminate flowers, the fertile staminate flowers 2-5 (usually 4), the synandrium retuse at the apex, the stamens fused together only on the inner side. Infructescences pendent; fruiting spadix $7-7.8 \mathrm{~cm}$ long, 1.4-2 cm diam. Figs. 35, 36.

Distribution: The species is known from Jamaica, Cuba and Hispaniola in the West Indies. It is the type species for the genus. The species can be recognized by its elongate spathe tube and the spathe blade which is up to twice as long as the staminate part of the spadix. An unnumbered Hitchcock collection at MO from Lucea, Jamaica, is anomalous in having the median lobe with a conspicuously sinuate margin. The species frequently has weakly irregular margins and the Hitchcock collection seems to be merely a gross exaggeration of this character.

According to Birdsey (1955) the species may flower all year but no particular individual is in flower continuously.

CubA: Principes, near railroad, Shafer 421 (CM).

HAITI: DUNORD: Trail between Milot and Citadel, Fairchild s.n. (US); Port Margot to Cornell, Nash 185 (NY); Vicinity of Dondon, Leonard 8671 (US). NORDouEST: Vicinity of Bassin Bleu, Leonard 14894 (US). Ile de la Gonave, vicinity Anse Galette, Leonard 3078 (US).

Jamaica: HANOVER: Lucea, Hitchcock s.n. (MO). MANCHESTER: Bethany, Wolle s.n. (CM); Mande Ville, Britton 1053 (NY). PORTLAND: Port Antonio, Hitchcock s.n. (MO); Stony River Base Camp, $1250 \mathrm{ft}$, Morley \& Whitefoord 686, 708 (MO). sT. ANDREw: Kingston, Hope Gardens, Skutch s.n. (F). ST. CATHERINE: Bog Walk, Hitchcock s.n. (MO). ST. THOMAS: Fountain Inn, $500 \mathrm{ft}$, Yuncker 17526 (F, MICH); House Hill, Maxon 9047 (NY, US). TRELANY: Windson, Miller 1455 (US).

18. Syngonium erythrophyllum Birdsey ex Bunting, Baileya 14:17. 1966. TYPE: Panama, Canal Zone, near Fort Randolph near the Atlantic coast, Maxon \& Harvey 6536 (US, holotype). 

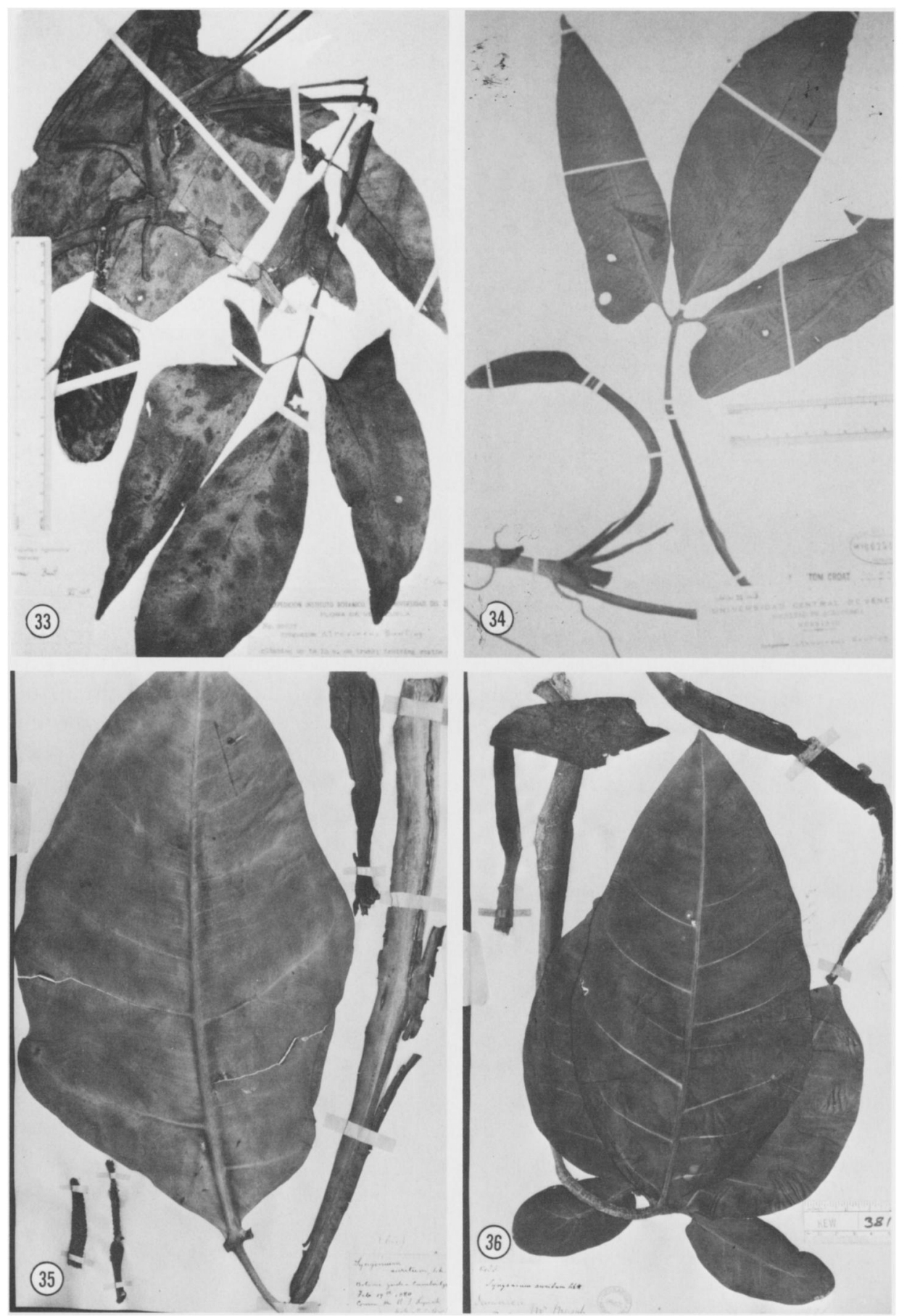

FiguREs 33-36.-33. Syngonium atrovirens, Steyermark \& Fernandez 99663; adult plant with mature infructescence.-34. S. atrovirens, Bunting 2776; adult plant with juvenile infructescence. 35 . S. auritum, Lynch s.n.; median segment of adult blade with petiole and loose spadix $\left(\times^{1 / 3}\right),-36 . S$. auritum, March 1433; adult blade with inflorescence. 
Juvenile plants often solitary; stems with short internodes, later scandent, branching, slender, leafy; blades ovate, 3-9 cm long, \pm cordate at the base, the lobes rounded, the sinus \pm arcuate with the decurrent petiole, the upper surface blackish green, the lower surface at first green, soon becoming deep violet purple; juvenile blades on climbing stems larger, simple, sagittate, dark green above, deep violet purple below, 9-17 cm long, becoming indistinctly 3-lobed; petioles $11-20 \mathrm{~cm}$ long, sheathed to near the apex. Adult plants with stems sometimes branching, green, not glaucous, usually less than $1 \mathrm{~cm}$ wide, the periderm thin, minutely papillate, flaking and pale reddish brown at maturity; petioles $9-20 \mathrm{~cm}$ long, sheathed $4 / 5$ or nearly throughout its length; blades trisect, subcoriaceous, the surface dark green and shiny above, paler beneath, usually green, sometimes violet purple; leaflets usually completely free, spreading or slightly overlapping, acuminate to rounded at the apex, ending abruptly with a minute apiculum; median leaflet elliptic to lanceolate-elliptic or narrowly ovate, 10-22 cm long, 4.5$10 \mathrm{~cm}$ wide, obtuse to attenuate at the base; lateral leaflets $4.5-10 \mathrm{~cm}$ long, $1.2-$ $4.3 \mathrm{~cm}$ wide, elliptic to lanceolate or oblong, obtusely and narrowly rounded at the apex, the base inequilateral but not auricled. Inflorescences usually 2 or 3 per axil; peduncles 3-11 cm long, green, not glaucous, erect at anthesis, pendent in fruit; spathe equalling or longer than the spadix; spathe tube green, $2-4 \mathrm{~cm}$ long, 1-1.5 cm diam., ovoid to ellipsoid; spathe blade white, ovoid to ellipsoid (when flattened), 8-11 cm long, 5-6 cm wide, weakly reflexed away from the spadix at anthesis; spadix 9-13.5 cm long; pistillate portion of the spadix to 1.5$1.8 \mathrm{~cm}$ long, the pistils ca. $1.4 \mathrm{~mm}$ diam., the stigmas discoid, ca. $0.9 \mathrm{~mm}$ diam.; staminate portion of the inflorescence $6.5-10 \mathrm{~cm}$ long, (the fertile part $6-9 \mathrm{~cm}$ long), the flowers 4-androus, truncate or slightly retuse at the apex, the pollen white in arachnoid clusters. Infructescences ovoid, yellowish green, 3-5 cm long, the tube opening at maturity; seeds white, \pm oblong, rounded on one end, apiculate and angled on the other end, 6-7 mm long. Figs. 41, 46.

Distribution: Syngonium erythrophyllum is known only from Panama at elevations from sea level to $350 \mathrm{~m}$ in tropical moist forest and premontane wet forest life zones. Birdsey (1955) reports that this species may also occur in the Reventazón Valley of Costa Rica (provinces of Cartago and Limón) because he saw similar juvenile leaves on Syngonium plants collected there.

It is not confused with any other species and is recognized by its thick, trisect, slightly auriculate leaves with violet purple lower surfaces, at least on juvenile blades. Stems dry with a conspicuous, flaky, reddish brown periderm. The frequently rounded and apiculate-tipped leaflet apices are another useful character in recognizing the species.

On Barro Colorado Island this species produces abundant juvenile plants but few adult plants were seen during more than three years of field work there.

Flowers have been found mostly March-June and fruits in August-September.

Panama: Canal zone: Barro Colorado Island, Birdsey 349 (UC, US), Croat 6208, 8637, 9124, 11709 (MO), 11778 (F, MO, US), 14955 (F, MO), Knight s.n. (US); Near Fort Randolph, Maxon \& Harvey 6536 (US), Shattuck 31 (F), Wetmore \& Woodworth 31, 875 (F, GH). PANAMÁ: El LlanoCartí Road, Croat 33800, 34801 (MO), Folson 2258 (MO).

19. Syngonium gentryanum Croat, sp. nov. TYPE: Peru, Huánuco, La Divisora, Tingo María-Pucallpa, road near Loreto border, 1150-1250 m, premontane 
rain forest, Gentry, Daly \& Cruz 18822 (MO-2415210, holotype; USM, isotype).

Caudex ca. $2 \mathrm{~cm}$ diam.; lamina trisecta; petiolus ad $63 \mathrm{~cm}$ longus; vagina 16-28 cm longa, lamina media oblonga-elliptica, $27 \mathrm{~cm}$ longa, $9.3 \mathrm{~cm}$ lata; lobi laterales lobum medium aequantes, inaequalateres haud auriculatos. Inflorescentia 2 in axilla; pedunculus $7 \mathrm{~cm}$ longus; spathae tubus oblongusellipticus, $2.5-3.5 \mathrm{~cm}$ longus, $1.1-2.3 \mathrm{~cm}$ diam.; spathae lamina elliptica, acuminata; spadix ca. $8 \mathrm{~cm}$ longa, parte feminea spadicis $7 \mathrm{~mm}$ longa, $4 \mathrm{~mm}$ diam.

Adult plants with stems ca. $2 \mathrm{~cm}$ diam.; petioles to $63 \mathrm{~cm}$ long, sheathed to 16-28 cm, slender, less than $1 \mathrm{~cm}$ diam., the sheath merging imperceptibly with the petiole at the apex; blades trisect, the lobes narrowly confluent at the base, the median lobe oblong-elliptic, acuminate at the apex, cuneate at the base, 27 $\mathrm{cm}$ long, $9.3 \mathrm{~cm}$ wide, drying pale yellowish brown, matte on the upper surface, slightly paler on the lower surface, the lateral lobes equal to the median lobe, 27$27.5 \mathrm{~cm}$ long, $7.5-8 \mathrm{~cm}$ wide, very inequilateral, the inner margin narrowly acute, almost paralleling the margin near the base, the outer margin attenuate and acute at the base, not at all auriculate, the lateral lobes markedly inequilateral, oblonglanceolate, acuminate at the apex, ca. $26 \mathrm{~cm}$ long and $8 \mathrm{~cm}$ wide, the inner edge narrowly acute at the base, narrowly confluent with the median lobe, the outer edge acute to obtuse, the midrib drying more or less flat on the upper surface, raised beneath; primary lateral veins $3-4$ pairs; the tertiary veins weakly visible; the principal collective vein 3-6 $\mathrm{mm}$ from the margin. Inflorescences 2 per axil, $10-11 \mathrm{~cm}$ long, slender; peduncles ca. $7 \mathrm{~cm}$ long, drying less than $4 \mathrm{~mm}$ diam.; spathe tube oblong-ellipsoid, $2.5-3.5 \mathrm{~cm}$ long (dried), $1.1-2.3 \mathrm{~cm}$ diam.; spathe blade, whitish, oblong-elliptic, narrowly acuminate at the apex; spadix to $8 \mathrm{~cm}$ or longer; pistillate portion of the spadix $7 \mathrm{~mm}$ long, $4 \mathrm{~mm}$ diam., the stigmas ovoid, $0.6-0.7 \mathrm{~mm}$ diam., slightly broader in the direction of the axis, contiguous; staminate portion of the spadix narrowly clavate, ca. $7.5 \mathrm{~cm}$ long or more, ca. 7 $\mathrm{mm}$ diam., the flowers irregularly 4-6-sided, 1-2 $\mathrm{mm}$ diam. (dried), the apex truncate, lacking a medial depression, shallowly incised along the sides between each stamen. Infructescences not seen. Fig. 42.

Distribution: The species is known only from the type locality in premontane rain forest in Huánuco Department, Peru. It is named in honor of Dr. Alwyn $\mathrm{H}$. Gentry who made the only known collection of the species.

It is distinguished from other South American species by its trisect leaves with the lateral lobes not at all auriculate and equal to the median lobe in length. Syngonium gentryanum is probably closest to $S$. sparreorum of western Ecuador. See that species for a discussion of the differences.

The type had a flowering inflorescence in March.

Peru: huÁnuco: La Divisora, Tingo María-Pucallpa road near Loreto border, Gentry et al. 18822 (MO, USM).

20. Syngonium glaucopetiolatum Croat, sp. nov. TYPE: Panama, Chiriquí, E of Boquete along steep forested slopes on Cerro Azul near Quebrada Jaramillo, 1620-1700 m, Croat 26821 (MO-2272459, holotype).

Caudex haud glaucus, scandens, internodiis $2.5 \mathrm{~cm}$ diam.; foliorum petiolus $25-30 \mathrm{~cm}$ longus, ad $2 / 3$ longitudinis usque vaginatus; petiolus juvenalis valde glaucus; lamina trisecta; segmentum medium 15-25 cm longum, 11-15 cm latum, ellipticum apice acuminatum; segmenta lateralia 16-24 cm longa, $10-12 \mathrm{~cm}$ lata, basi valde inaequalatera, valde auriculata, lateribus exterioribus lateribus, interioribus 

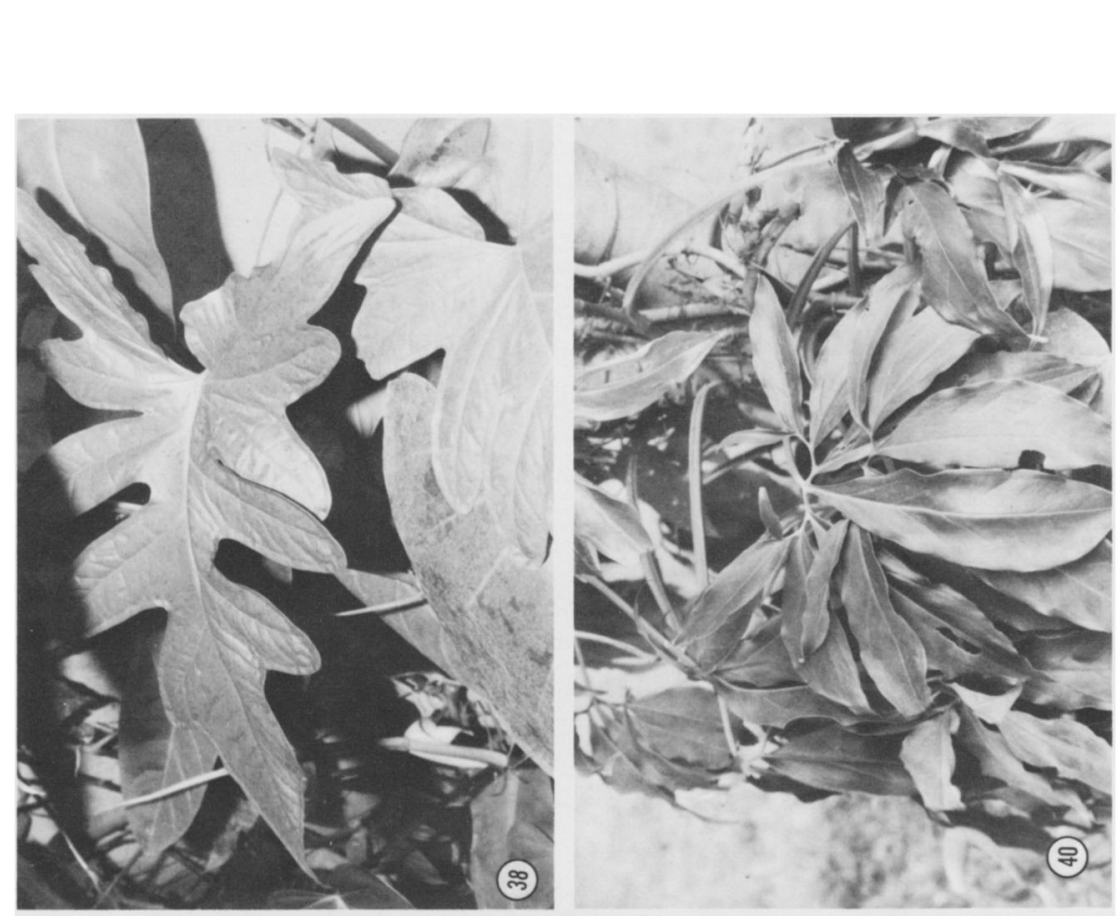

穴
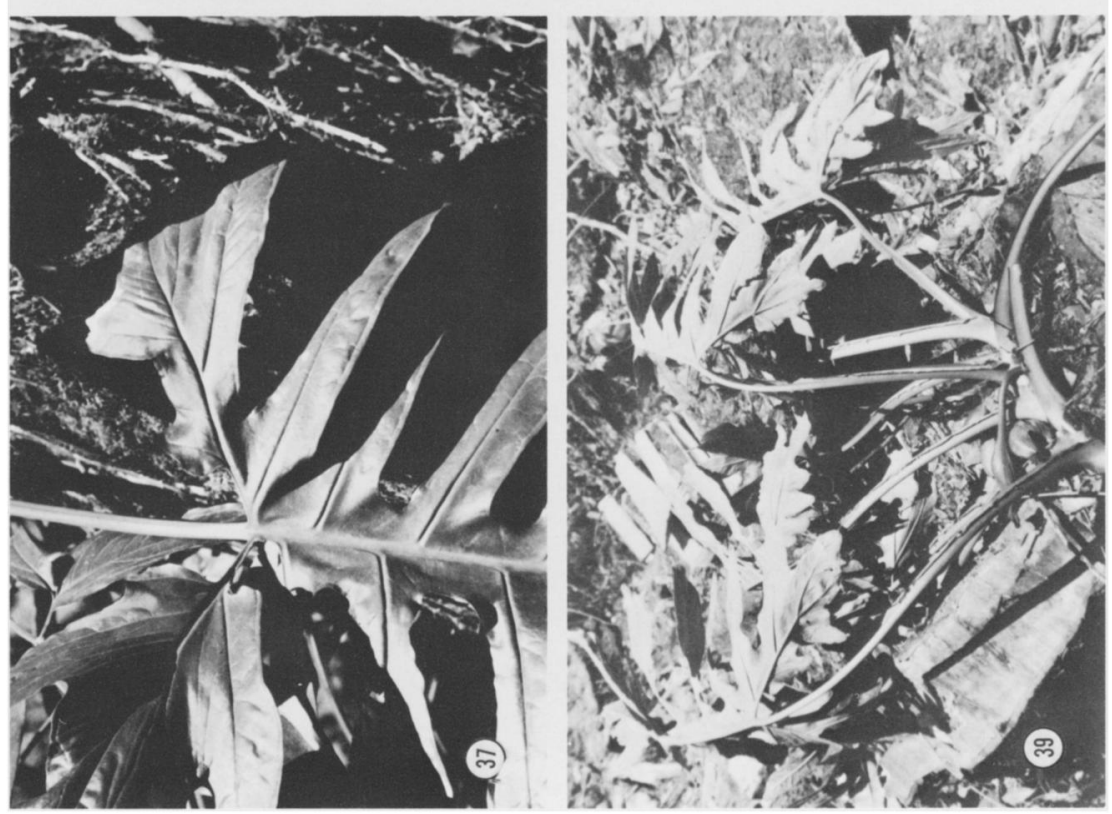

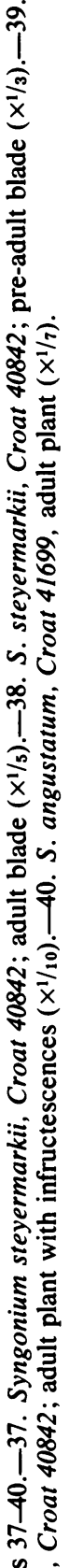

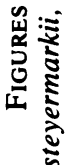


cuneatis. Inflorescentiae binatae; pedunculus $15 \mathrm{~cm}$ longus, valde glaucus; spathae tubus $6-7 \mathrm{~cm}$ longus, $5 \mathrm{~cm}$ latus, ovatus-ellipticus, valde glaucus.

Hemiepiphytic creeper. Juvenile plants with stems ca. $5 \mathrm{~mm}$ diam., the epidermis drying brown, peeling; petioles $9-13 \mathrm{~cm}$ long, D-shaped above the sheath, becoming sharply angular on pre-adult and adult plants; blades ovate-triangular, narrowly acute at the apex, mucronate, sagittate at the base, $13 \mathrm{~cm}$ long, ca. 5 $\mathrm{cm}$ wide at the middle, the posterior lobes $5-5.5 \mathrm{~cm}$ long, the posterior lobes soon pinched off and directed outward at $45^{\circ}$ angle, noticeably auriculate at the base; intermediate blades with the lateral segments confluent with the medial lobes. Adult plants with stem to $2.5 \mathrm{~cm}$ diam. (fresh), shrinking to $1.5 \mathrm{~cm}$ diam., the epidermis green, shiny, drying yellowish brown with sharp longitudinal wrinkles; internodes $2-4 \mathrm{~cm}$ long; leaves moderately thin, clustered in the upper 30 $\mathrm{cm}$ of the stem; petioles $25-30 \mathrm{~cm}$ long, sheathed ca. $2 / 3$ their length, the sheath 4-5.5 $\mathrm{cm}$ wide when flattened, free-ending and bluntly acute at the apex, the upper part of the petiole subterete with a blunt medial rib; blades trisect, at least sometimes confluent to almost free; median leaflet elliptic, $15-25 \mathrm{~cm}$ long, 11-15 $\mathrm{cm}$ wide, acuminate at the apex, briefly attenuate at the base; lateral leaflets strongly inequilateral, $16-24 \mathrm{~cm}$ long, $10-12 \mathrm{~cm}$ wide, the base prominently auricled on the outer margin, cuneate on the inner margin, the midrib bluntly depressed above, prominently raised beneath, the primary lateral veins and the principal collective vein weakly sunken above, raised beneath, the tertiary veins clearly visible (on dried specimens); primary lateral veins 6-8 pairs, mostly departing midrib at ca. $40^{\circ}$ angle; collective vein ca. $12-18 \mathrm{~mm}$ from the margin (midway to the apex). Inflorescences 2 per axil; not seen in flower. Infructescences pendent; peduncle to $15 \mathrm{~cm}$ long; peduncle and spathe tube pruinose; spathe tube ovoid-ellipsoid, 6-7 cm long, ca. $5 \mathrm{~cm}$ diam. (fresh); spathe blade (dried) brown, subcoriaceous, ca. $10 \mathrm{~cm}$ long, acuminate at the apex, sometimes persisting in its dried condition; mature fruits not seen. Figs. 43, 47.

DISTRIBUTION: Syngonium glaucopetiolatum is known from Costa Rica where I have seen it at Monteverde (Guanacaste) and Panama in what is believed to be lower montane wet forest at elevations of $1300-1800 \mathrm{~m}$.

It is distinguished by its large 3-lobed blades with markedly auriculate lateral lobes and by its glaucous young petioles, peduncles, and spathe tubes. The blade shape of $S$. glaucopetiolatum approaches that of $S$. mauroanum but that species has been found to range no higher than $450 \mathrm{~m}$ and is apparently restricted to premontane moist forest.

The species presumably flowers early in the rainy season, perhaps in June, because immature fruits have been seen in August and fruits of mature size have been seen in February.

PANAMA: ChIRIQuí: East of Boquete, Croat 26821 (MO).

21. Syngonium harlingianum Croat, sp. nov. TYPE: Ecuador, Pastaza, Mera, Pantanos, $1100 \mathrm{~m}$, Harling 11064 (GB, holotype).

Planta terristris, caudex ca. $1 \mathrm{~cm}$ diam.; lamina simplex trilobata, lobi conjuncti, lobus medius $7.5-10.5 \mathrm{~cm}$ longus, $2.7-6 \mathrm{~cm}$ latus, lobi laterales inaequilaterae conspicuae auriculatae. Inflorescentia solitaria, $9.5 \mathrm{~cm}$ longa, spatha $11.5 \mathrm{~cm}$ longa, tubo $4.5 \mathrm{~cm}$ longo, ca. $2 \mathrm{~cm}$ lato, viridi, lamina luteola, acuminata; spadix $8.5 \mathrm{~cm}$ longa, parte feminea spadicis ca. $2 \mathrm{~cm}$ longa. 
Terrestrial. Adult plants with stems ca. $1 \mathrm{~cm}$ diam.; internodes $1-2 \mathrm{~cm}$ long near the apex; petioles $12-14 \mathrm{~cm}$ long, sheathed ca. $2 / 3$ their length, the free portion subterete, ca. $2 \mathrm{~mm}$ diam., the sheath merging almost imperceptibly with the petiole at its apex; blades 3-lobed, drying yellowish green, the median lobe oblong-elliptic, acuminate to obtuse at the apex, narrowed at the base and confluent with the lateral lobes, $7.5-10.5 \mathrm{~cm}$ long, $2.7-6 \mathrm{~cm}$ wide, the lateral lobes markedly inequilateral (the inner part $1 / 2$ or less as wide as the outer part), more or less elliptic, obtuse to acute at the apex, 5.5-8 cm long, $2-4 \mathrm{~cm}$ wide, rounded or more commonly auriculate on the outer edge at base, the midrib naked for 5$10 \mathrm{~mm}$, the auricles to $2.5 \mathrm{~cm}$ long, rounded or oblong, not at all constricted at the base, the surfaces drying matte, yellowish green, slightly paler beneath; midrib drying flat on upper surface, weakly raised beneath with obscure scabrid lines; primary lateral veins $2-4$ pairs; tertiary and quaternary veins distinctly visible; primary collective vein arising from the first or second primary lateral vein, 2-4 $\mathrm{mm}$ from the margin. Inflorescences solitary; peduncle $9.5 \mathrm{~cm}$ long, ca. $3 \mathrm{~mm}$ diam. (dried); spathe $11.5 \mathrm{~cm}$ long; spathe tube green, narrowly ellipsoid, $4.5 \mathrm{~cm}$ long, ca. $2 \mathrm{~cm}$ diam.; spathe blade narrowly elliptic, membranous, yellowish, acuminate at the apex; spadix $8.5 \mathrm{~cm}$ long; pistillate portion of the spadix ca. 2 $\mathrm{cm}$ long, ca. $5 \mathrm{~mm}$ diam., the flowers contiguous, ca. $1 \mathrm{~mm}$ diam.; sterile staminate flowers irregularly elongated in the direction of the axis, 3-3.5 mm long in direction of the axis, $1-1.6 \mathrm{~mm}$ wide perpendicular to axis; staminate portion of the spadix cylindroid, narrowly tapered toward the apex, drying ca. $1 \mathrm{~cm}$ diam., the flowers mostly rhombic, the apex truncate, matte, the margin crenate, not at all incised between the anthers. Infructescences not seen. Fig. 44.

DisTRIBUTION: Syngonium harlingianum is known only from the type collection and is named in honor of its collector, Dr. Gunnar Harling, one of the coauthors of the Flora of Ecuador.

The species is not closely related to any other species nor is it confused with any other species. It is characterized by its small, 3-lobed leaves with confluent leaflets. It was described by its collector as being terrestrial, an unusual condition in the genus. While it is not unusual to find juvenile and pre-adult leaves on the ground, I have never found adult plants in other than an epiphytic or hemiepiphytic situation.

The type collection was in flower in late February.

Ecuador: Pastaza: Mera, Harling 11064 (GB).

22. Syngonium hoffmannii Schott, Oesterr. Bot. Z. 8:178. 1858. TYPE: Costa Rica, Alajuela, Candelaria, Alto de Sta. Cruz (presumably the modern day Candelaria southeast of San Ramón and Palmares at ca. 1000 m) Hoffmann s.n. (not seen) (Schott drawing of the Hoffmann collections, Schott Aroideae \#3212 was seen).

Porphyrospatha hoffmannii (Schott) Engler in A. DC., Monogr. Phan. 2:291. 1879.

Juvenile plants with glaucous stems; internodes $1-4 \mathrm{~cm}$ long, 3-6 mm diam.; petioles sheathed $1 / 2-2 / 3$ their length; blades sagittate, $4-13 \mathrm{~cm}$ long, medium green or with grayish white midrib and primary lateral veins (fide Birdsey, 1955), all 

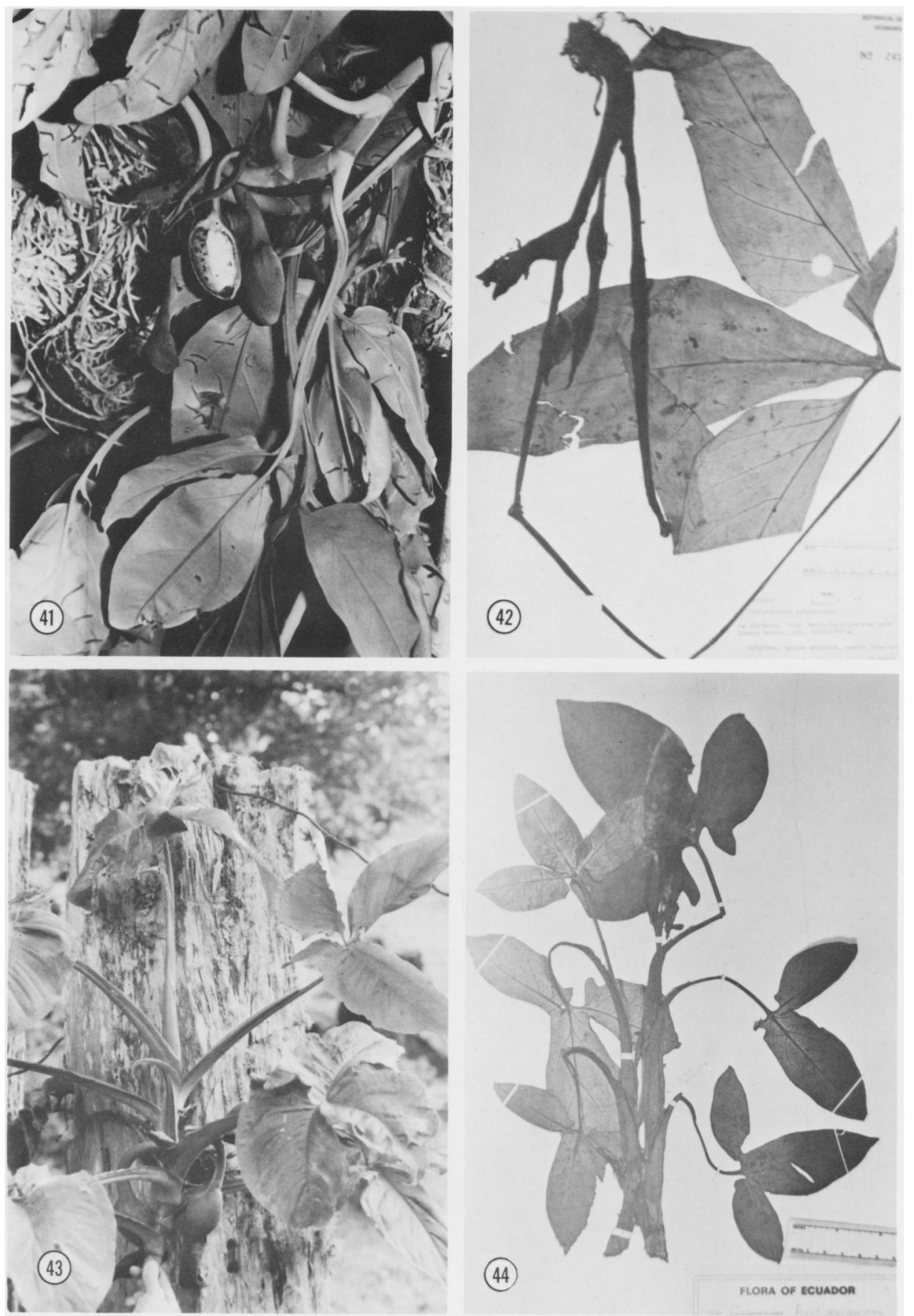

FIGURES 41-44.-41. Syngonium erythrophyllum, Croat 11778; adult plant with mature-sized infructescences $\left(x^{1 / 5}\right)$. - 42. S. gentryanum, Gentry et al. 18822; adult plant with inflorescence. -43 . S. glaucopetiolatum, Croat 26821 ; adult plant with infructescences $\left(x^{1 / 8}\right) .-44$. S. harlingianum, Harling 11064; adult plant with inflorescence. 
the major veins sunken above, raised beneath, the anterior lobe 4-18 cm long, ovate-deltoid, slightly or not at all constricted at the base, acute to acuminate and apiculate at the apex, the posterior lobes $2.5-9 \mathrm{~cm}$ long, acute to acuminate at the apex; intermediate leaves with the lateral lobes only slightly inequilateral or very inequilateral but lacking a conspicuous, protruded auricle. Adult plants with stems sometimes glaucous, usually $1-2 \mathrm{~cm}$ wide; internodes weakly sulcate above the petioles, $1.5-10 \mathrm{~cm}$ long on flowering branches, olive green, drying brown, flaky, often weakly and rather sparsely muricate; petioles sometimes glaucous, paler than the stems, $12-33 \mathrm{~cm}$ long, sheathed $2 /{ }_{3}-4 / 5$ their length, subterete above the sheath, somewhat flattened laterally, sharply to bluntly 1-ribbed adaxially; blades trisect (or rarely sub-5-sect); leaflets free to confluent, 9-28 cm long, 3.5$11 \mathrm{~cm}$ wide, the upper surface medium green, semiglossy, the lower surface only slightly paler; median leaflet oblong-elliptic to ovate-oblong or lanceolate, equal or more frequently unequal, acuminate at the apex, obtuse to acute or attenuate at the base; lateral leaflets $6-24 \mathrm{~cm}$ long, 2-8 cm wide, very unequal, acute on the inner margin at the base, usually prominently auriculate on the outer margin at the base, the auricles directed downward and in line with the leaflet or directed somewhat outward, usually \pm parallel with the petiole, strongly to not at all pinched off from the leaflet (rarely appearing as another leaflet); primary lateral veins 5-10 pairs, sunken on the upper surface, raised beneath, the minor veins obscure on the upper surface. Inflorescences usually 1-3 (less frequently to 4 in Panama) per axil; peduncles sometimes glaucous (commonly glaucous at higher elevations), 3-9 cm long and erect at anthesis, 6-13 cm long and pendent in fruit; spathe tube broadly ovoid to ovoid-ellipsoid, dark green outside, becoming tinged with purple in age, red to violet purple within, $4-4.5 \mathrm{~cm}$ long, 2-2.5 cm diam.; spathe blade broadly ovate, greenish white to white, cuspidate at the apex, 5.5$8 \mathrm{~cm}$ long, $4.8-5.5 \mathrm{~cm}$ wide; pistillate portion of the spadix greenish, $2-2.5 \mathrm{~cm}$ long, tapered gradually toward the apex, $1.2-1.6 \mathrm{~cm}$ diam., the flowers 2-carpellate, the stigma 2-lobed, circular, the syncarp 3-4 $\mathrm{mm}$ diam. at the apex; staminate portion of the spadix white, $5.5-9 \mathrm{~cm}$ long, $1.4-1.7 \mathrm{~cm}$ diam., broadest at about the middle, only slightly constricted at the point of merger with the sterile staminate flowers, then slightly broader toward the base, the fertile staminate flowers regularly to irregularly 4-lobed, the sterile staminate flowers slightly larger, irregular, closely compacted. Infructescences usually oblong-ellipsoid (sometimes ellipsoid), green heavily tinged with purple or sometimes yellowish (fide herbarium labels), 6-10 cm long, $3-4.5 \mathrm{~cm}$ wide; syncarp white, to $5.5 \mathrm{~cm}$ long and 3.5 cm diameter. Figs. 48, 49, 53.

Distribution: Syngonium hoffmannii ranges from northern Costa Rica to Cerro Pirre in eastern Panama. It usually occurs in lower montane rain forest but is also frequent in premontane rain forest and tropical wet forest. It has also been collected, though much less frequently, in premontane wet forest.

The species is an extremely variable one and might eventually prove to consist of more than one element. Altitudinal range is particularly great ranging from 300 $\mathrm{m}$ to $1800 \mathrm{~m}$. The greatest differences are exhibited in the degree of lobing of the lateral leaflets, in the shape and coloration of the infructescences, and in the degree to which petioles and inflorescences are glaucous. More Costa Rican and Panamanian collections at higher elevations were reported to have glaucous parts. 

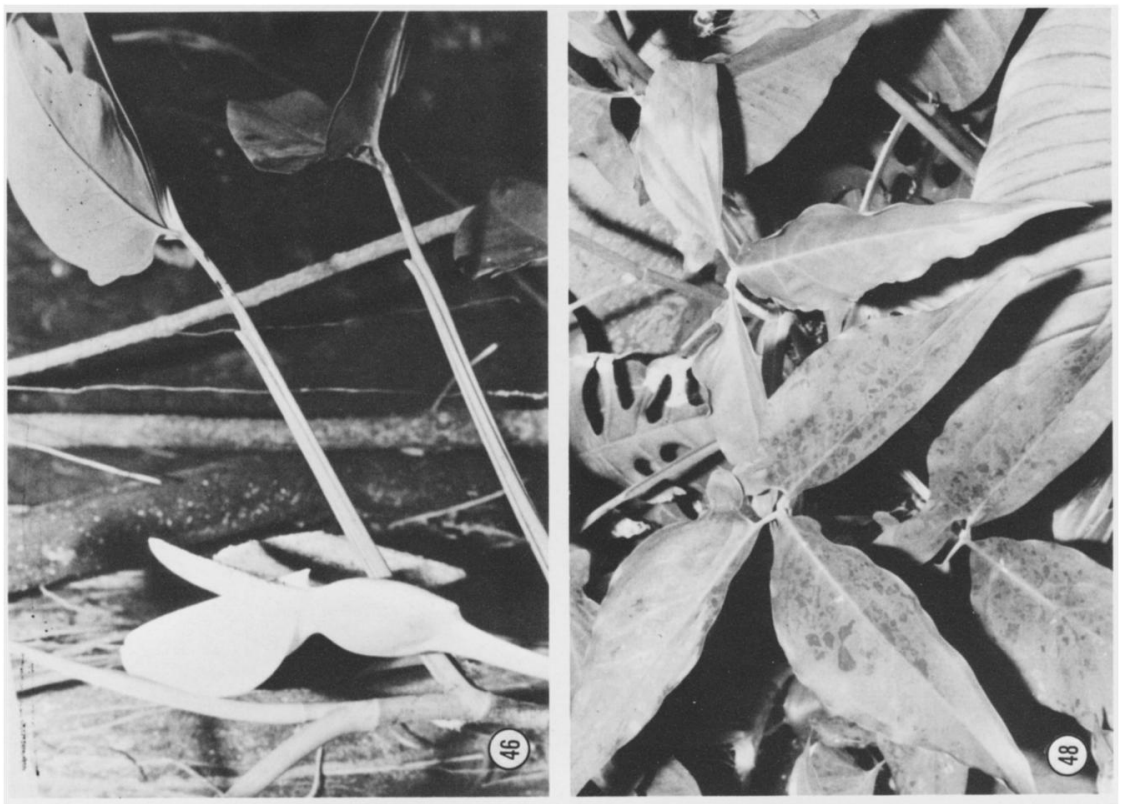

ปั

E

.

ส

ป

ส

क्ष

西学

莺于

के

랄

돈 $\frac{n}{n}$

3.

.를

एँ

3. :

过

$>$ 政

สํำ

퐁

늘

氙青

洁 흠
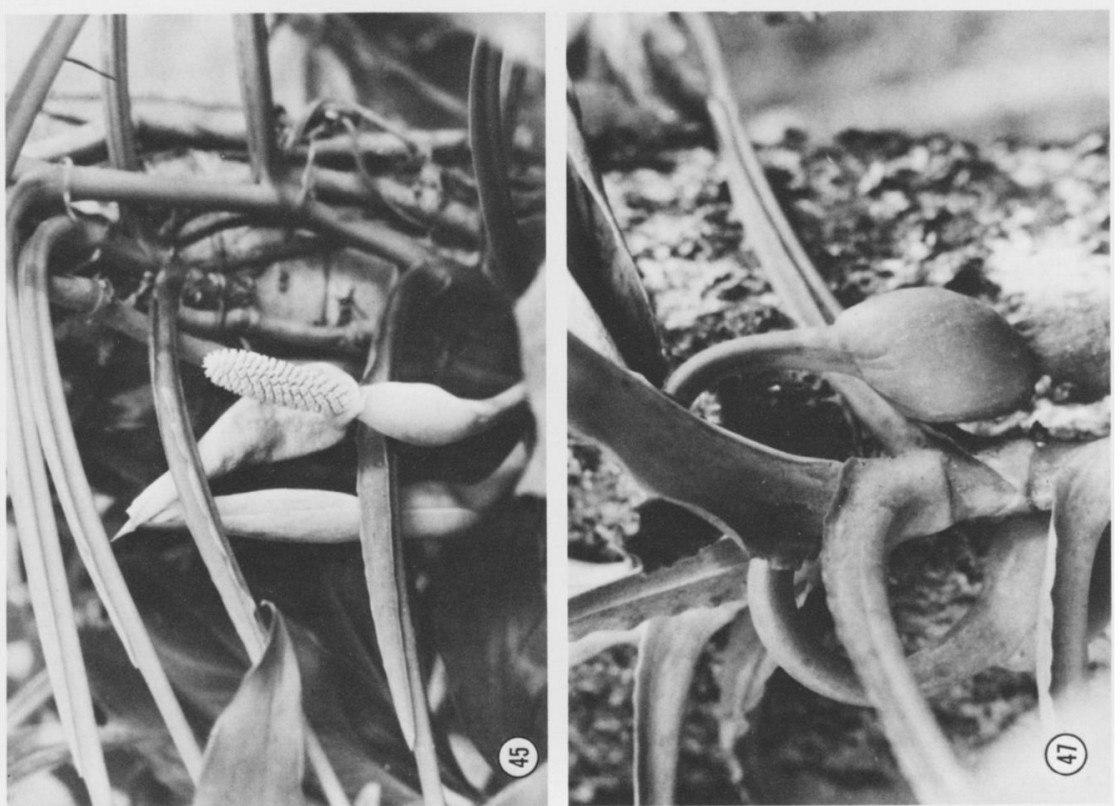

递

淧文

获

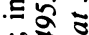

ลับ

18

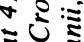

¿ 2

บ

हं ลำ

डิ

25

हों

$\dot{s} \dot{s}$

$\dot{s}$

zิ

两过

ऊत्र

$\because \cdot \stackrel{x}{*}$

Toi

安兘

守踪

压

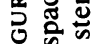

I

至 
The species might be confused in Costa Rica with $S$. wendlandii which has similar leaves. See that species for a discussion of the differences.

Flowers have been found in March, May, and December. Fruits are most common from July to September but have been seen immature from December to August.

Costa Rica: Alajuela: NNE of Bijagua, Burger \& Baker 9850, Croat 36268, 36270, 36515 (MO); NW of Zarcero, Croat 43532, 43575, 43627 (MO). CARTAGo: E of Cachí, Croat 47084 (MO); Between town of Jicotea and Río Pacuare, Croat 36558 (MO); SE of Platanillo, Croat 36731 (MO). HEREDIA: Near Cariblanco, Croat 35653 (MO); San José de la Montaña, Echeverria 4077 (F); N of Vara Blanca, Croat 35594, 35619 (MO). PUNTARENAs: N of La Unión, Croat 26686 (MO); Monteverde, Jiménez s.n. (MO). SAN José: Santa María de Dota, Standley 42097, Standley \& Valerio 43322 (US).

Panama: ChIRIQuí: Vicinity of Cerro Colorado and Escopeta, Croat 33508, 48441 (MO); Fortuna Dam Site, Croat 48669, 48722, 48804, 49885, 50025 (MO); Las Lagunas near Volcán, Folsom \& Page 5979 (MO); Monte Rey above Boquete, Croat et al. 15667 (MO). CocLÉ: La Mesa above El Valle de Antón, Croat 37341A (MO); Alto Calvario above El Copé, Croat 49201, 49207 (MO). Colón: E of Santa Rita Ridge, Correa \& Dressler 637 (SCZ), Croat 13893, 34351 (MO). DARIÉn: Summit of Cerro Pirre, Gentry \& Clewell 7027 (MO); Vicinity Río Tuquesa, Croat 27180 (MO). Herrera: Above Chepo de las Minas, Folsom, Channell \& Small 7009 (MO). PANAMÁ: Cerro Azul, Croat 17268 (MO), Dwyer 4100 (MO), Tyson \& Blum 4100 (SCZ); Cerro Campana, Croat 12075, 14226, 25251, 35948, 35962, Porter et al. 4215 (MO), 4262 (MO, US); Vicinity Cerro Jefe, Croat 35921 (MO), Lewis et al. 226 (F, GH, K, MO, NY, UC, US), Tyson et al. 3354 (SCZ); Wilbur et al. 15572 (MO); El LlanoCartí Road, Croat 33776, 34805A, Mori \& Kallunki 4092 (MO); Vicinity Finca Neptuno, Nee 11534 (MO); Vicinity of La Eneida, Luteyn \& Kennedy 1755 (DUKE, MO). VERAgUAS: Between Alto Piedra and Calovebra, Croat 27391 (MO); N slope of Cerro Alto Higo (El Montoso), Hammel 4267 (MO); Along Río Primero Braso, Croat 25970, Liesner 827 (MO); Vicinity of Santa Fe and Río Calovebra, Croat \& Folsom 33986, Croat 34195, 34231, 48888, 48889 (MO); Beyond Tres Brazos River, Croat 25647 (MO).

23. Syngonium laterinervium Croat, sp. nov. TYPE: Costa Rica, Puntarenas, Osa Peninsula, Corcovado National Park within $2 \mathrm{~km}$ of park headquarters at Sirena, below $200 \mathrm{~m}, 8^{\circ} 29^{\prime} \mathrm{N}, 8^{\circ} 36^{\prime} \mathrm{W}$, Liesner 2951 (MO-2588405, holotype).

Caudex scandens haud glaucus, internodiis 2-8 cm longis, 5-10 $\mathrm{mm}$ diam.; foliorum petiolus 10 $20 \mathrm{~cm}$ longus, vaginatus praeter $1-3 \mathrm{~cm}$ distale, lamina trisecta, segmentum medium oblongum-ellipticum, leviter inaequalaterum, (5.5-)8-17 cm longum, $2.3-5.5 \mathrm{~cm}$ latum, apice acuminatum, mucronulatum, basi acutum ad attenuatum, segmenta lateralia (5.2-)9-14 cm longa, $2.5-4 \mathrm{~cm}$ lata, oblongaelliptica, inaequalatera basi auriculata; folia venis lateralibus utroque latere 4-6, nervis parvis vix prominioribus, subangulo ca. $10-20^{\circ}$. Inflorescentia pedunculo $4.5 \mathrm{~cm}$ longo, in axilla solitarius; spathae tubus ca. $3.5 \mathrm{~cm}$ longus, $1.2 \mathrm{~cm}$ diam., anguste ellipticus, extus viridis pallidus; spathae lamina ca. $5 \cdot \mathrm{cm}$ longa, alba.

Juvenile stages not seen. Adult plants with scandent stems, much branched; internodes 2-8 cm long, 5-10 mm wide, green, drying light brown, the periderm often flaky in small patches; petioles $10-20 \mathrm{~cm}$ long, sheathed except for the last $1-3 \mathrm{~cm}$, the sheath free-ending and narrowly acute at the apex, those subtending inflorescences much broader in the lower half, the portion between the petiole and blade flattened adaxially; blades trisect, the leaflets overlapping or not distinctly free from one another; median leaflet oblong-elliptic, somewhat inequilateral, acute and cuspidate to narrowly acuminate at the apex, obtusely cuneate to attenuate at the base, (5.5-)8-17 cm long, $2.3-5.5 \mathrm{~cm}$ wide; lateral leaflets oblongelliptic, very inequilateral, narrowly acute to attenuate on the inner margins at the base, conspicuously auriculate on the outer margins at the base, usually joining the petiolule at ca. $90^{\circ}$ angle, the petiolule $4-10 \mathrm{~mm}$ long, canaliculate on upper side, the margin continuous with the margin of both the median and lateral 
leaflets, the auricles about as long as or longer than broad, 12-28 cm long, oblong to triangular, rounded at the apex; midrib weakly sunken on upper surface, raised beneath; primary lateral veins 4-6 pairs, slightly more conspicuous than the smaller lateral veins, all the veins below clearly visible, departing the midrib at ca. $70^{\circ}$ angle, spreading almost straight to the collective vein; collective veins 2 or 3 , the principal one $2-5 \mathrm{~mm}$ from the margin. Inflorescences solitary; peduncle ca. 4.5 $\mathrm{cm}$ long, ca. $3 \mathrm{~mm}$ diam., erect at anthesis; spathe ca. $8.5 \mathrm{~cm}$ long, spathe tube narrowly ellipsoid, ca. $3.5 \mathrm{~cm}$ long, $1.2 \mathrm{~cm}$ diam., the outside pale green; spathe blade elliptic, ca. $5 \mathrm{~cm}$ long, acuminate at the apex, white; spadix ca. $7 \mathrm{~cm}$ long; pistillate portion of the spadix $1.8 \mathrm{~cm}$ long, ca. $9 \mathrm{~mm}$ diam., the flowers irregularly hexagonal, the stigmas flat at the apex, 1.5-2 mm diam.; staminate portion of the spadix ca. $5 \mathrm{~cm}$ long, clavate, ca. $1.5 \mathrm{~cm}$ diam. at the broadest point in the upper $1 / 3$, the fertile staminate flowers mostly rhombic to sometimes irregularly hexagonal at the apex, the surface minutely rugose, the margins weakly crenate. Infructescences unknown. Fig. 16.

Distribution: Syngonium laterinervium is known from southwestern Costa Rica and northwestern Panama in tropical wet forest life zones in the region surrounding Golfo Dulce, at elevations ranging from near sea level to $450 \mathrm{~m}$.

It is most easily confused with $S$. hoffmannii but differs in having the lateral veins departing the midrib at no less than ca. $70^{\circ}$ angle and in having the primary lateral veins only slightly more prominent than the lesser lateral venation. Syngonium hoffmannii has at least the lower primary lateral veins departing the midrib at a much sharper angle (ca. $50^{\circ}$ ), and much more conspicuous than the minor lateral veins (drying much darker than the surface).

The species was first collected by Paul Allen in 1951 and was not collected again until 1973. According to Allen 6035 the plant was a branching vine forming dense masses on the trunks of large trees in climax forest.

Flowers have been found in July.

Costa Rica: puntarenas: Corcovado National Park, Liesner 2951 (MO); Esquinas Forest, Allen 6035 (F, GH, US).

Panama: Chiriquí: West of Puerto Armuelles, Busey 605 (MO).

24. Syngonium macrophyllum Engler, Pflanzenr. IV. 23E (Heft 71):128. 1920. TYPE: Mexico (locality not known) (B, holotype, two specimens made from cultivated plants in Berlin).

Juvenile plants with glaucous stems (at least in the northern extreme of its range); petioles 7-25 cm long, sheathed ca. $1 / 2$ their length; blades subcoriaceous, broadly ovate, $8-16 \mathrm{~cm}$ long, $6-10 \mathrm{~cm}$ wide, the posterior lobes at first rounded, becoming sagittate, rounded at the apex; intermediate leaves with the apical lobe elliptic, acuminate at the apex, much constricted at the base, the posterior lobes becoming nearly pinched off, narrowly rounded to acute at the apex. Adult plants with stems glaucous (or possibly not in Panama) $3-4 \mathrm{~cm}$ diam., usually not branched and appressed to trees; internodes $1-4 \mathrm{~cm}$ long near the apex; petioles often glaucous, $25-60 \mathrm{~cm}$ long, sheathed $1 / 2-3 / 4$ their length with a weak to prominent rib between the sheath and the blade, the sheath free-ending and acute at the apex; blades subcoriaceous, pedatisect; leaflets 7-9, mostly free or the outer 
ones confluent, the lowermost usually variously auriculate, this soon pinched off to form a leaflet, dark to medium green on the upper surface, smooth, the lower surface light green; rachis sharply margined; median leaflet oblanceolate, elliptic, broadly elliptic or ovate-elliptic, acuminate to acute and down-turned at the apex, cuneate to abruptly attenuate at the base, $17-47 \mathrm{~cm}$ long, $5-18 \mathrm{~cm}$ wide; primary lateral veins 3 or 4 pairs in the median leaflet, weakly sunken above, raised below. Inflorescences 4-8 per axil; peduncles almost terete, glaucous in the northern part of the range, erect, 10-13 cm long at anthesis, 14-20 cm diam. and pendent in fruit; spathe tube ovate, green and glaucous outside, green to greenish tan inside, 3-5.5 cm long, 3-5 cm diam.; spathe blade 7-11.5 cm long, at first green, becoming cream, mucronate at the apex; pistillate portion of the spadix $1.5-3 \mathrm{~cm}$ long, ca. $2 \mathrm{~cm}$ diam. at the base, tapered to the apex, to $1.5 \mathrm{~cm}$ diam. at the apex, pale green, the flowers irregularly 5-6-sided, the stigma subsessile, discoid, yellowish at anthesis; staminate portion of the spadix oblong-ellipsoid, abruptly constricted just above the sterile staminate flowers, the fertile staminate flowers with 4 stamens, the synandrium with the line of fusion scarcely visible, the apex truncate or with a conspicuous central depression, the sterile staminate flowers somewhat larger. Infructescences often rather massive, 8-14 cm long, 5-8 cm wide, yellow and pruinose in the northern part of the range; syncarp narrowly ovoid to subglobular, 6-10 cm long, 3.5-6 cm wide, brown; mesocarp sweet smelling, fleshy; seeds obovoid, white before maturity, becoming dark gray, 1.4$1.8 \mathrm{~cm}$ long, ca. $1.5 \mathrm{~cm}$ wide. According to natives in Guatemala near Puerto Barrios, the spathe tube of the mature infructescence turns yellow, whereas in Panama immature fruits have been seen turning a pale brick red. Figs. 50, 51, $54-56,61$.

Distribution: Syngonium macrophyllum ranges from Mexico to Ecuador (Pacific slope only). Collections from Río Palenque Field Station reported by Dodson \& Gentry (1978) as $S$. podophyllum are also this species. I believe the latter species is restricted to the other side of the Andes. The species is known from wetter parts of tropical moist forest, premontane wet forest and tropical wet forest and ranges from sea level to $1100 \mathrm{~m}$. It is most common below $700 \mathrm{~m}$. In Panama the species is always found in good forest or along roads recently opened. While this is usually the case also in the remainder of its range, to the north one finds the plants frequently in more disturbed areas. However, in most cases it is possible that plants could have persisted in the areas where they were collected from earlier forest disturbances.

It is possible that the Panamanian plants from central Panama (chiefly west of the Isthmus on Santa Rita Ridge, the Pipeline Road, El Llano-Cartí Road, etc.) represent a distinct species. These collections (e.g., Croat 13952) differ in having only a few primary lateral veins, mostly restricted to the basal half of the blade. Panamanian plants do not have glaucous parts and tend to have somewhat smaller leaves with narrower segments than do collections made from the northern part of the range.

Syngonium macrophyllum is not usually confused with any other species and is distinguished by its large parts, smooth, subcoriaceous, 7-9-pedatisect leaves and by its ovate-cordate juvenile blades. It may be confused with $S$. podophyllum 

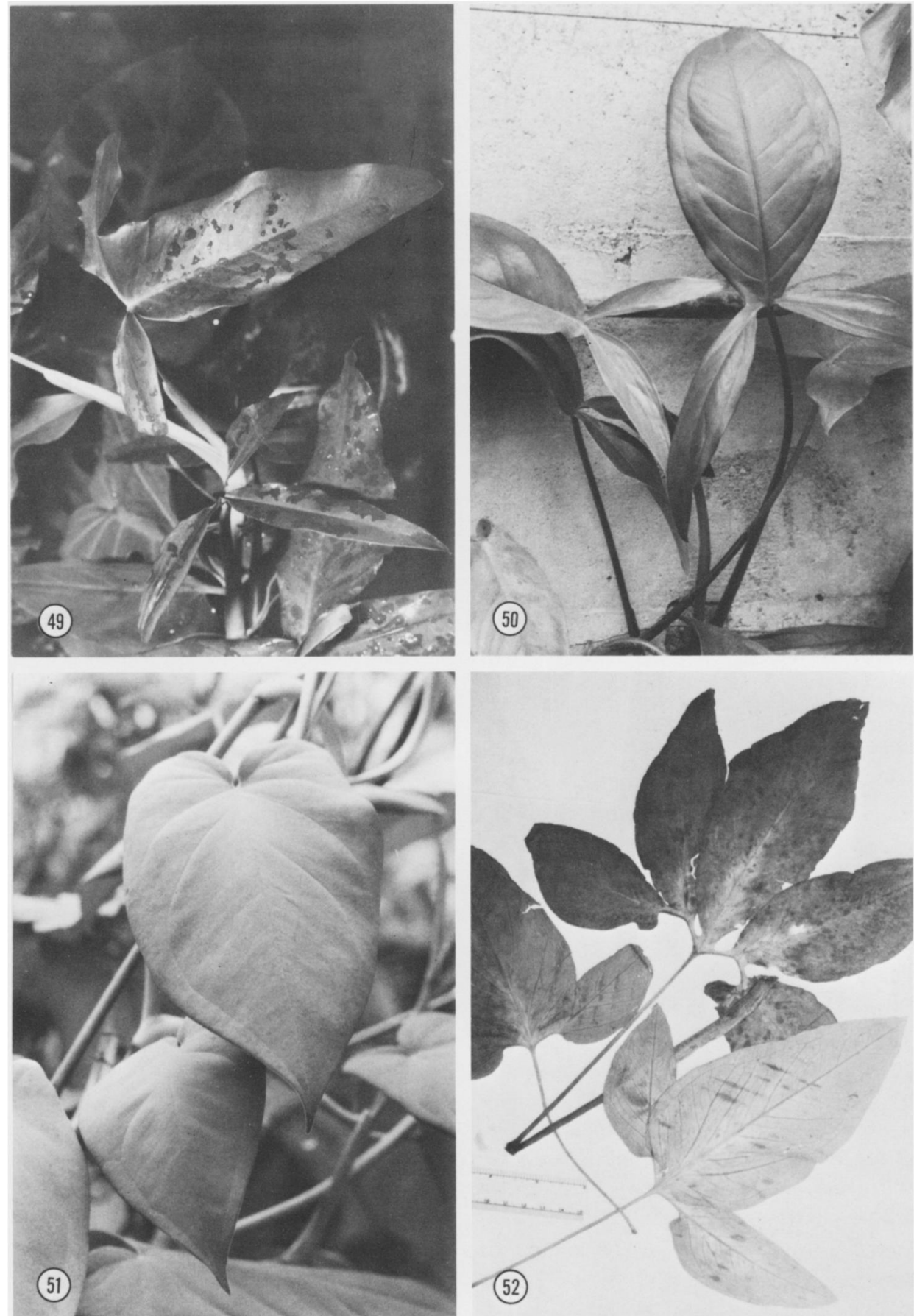

Figures 49-52.-49. Syngonium hoffmannii, Croat 33508; preadult blades $\left(\times^{1 / 5}\right)$.-50. S. macrophyllum, Croat 36339; pre-adult blades ( $\times 1 / 8) .-51$. S. macrophyllum, Croat 40140; juvenile stems and blades $\left(\times^{1 / 3}\right)$. -52. S. mauroanum, Bartlett \& Lasser 16708; adult blades showing the usual 3-lobed and the rare 5-lobed blades. 
in some parts of Panama and Costa Rica where they both occur in wetter parts of tropical moist or premontane wet forests.

Flowers and fruits are found throughout the year but principally from June to August.

Colombia: chocó: E of Quibdo, Forero \& Jaramillo 2637 (COL); Valley of Río San Juan near Docordo, Forero et al. 4351, 4546 (MO); E of Yuto, Gentry \& Renteria 24372 (MO).

Costa Rica: alajuela: Vicinity of Laguna Hule, Luteyn 3228 (DUKE, MO); Between Cañas and Upala, Burger \& Baker 9883 (F), Croat 36332, 36339, 36400, 36479, 36491 (MO). HEREDIA: Near Puerto Viejo, Croat 35721 (MO); S of Hone Creek on road to Bribri, Croat 43183 (MO).

ECUADOR: No other location, Eggers 15131, (F, GH, NY, US). ESMERALDAs: S of Esmeraldas, Sparre 15498 (S); San Lorenzo, Jativa \& Epling 724 (NY, UC), 738, 830 (UC). GUAYAS: Vicinity of Naranjito, Camp E-3584C, 3584B (NY). IMBABURA: Between Ibarra and Lita, Croat 38917 (MO). Los Ríos: Río Palenque Field Station, Croat 38677 (F, MO), Gentry 9986 (MO); Between Babahoyo and Montalve, Sparre 17961 (S). PICHINCHA: Santo Domingo Alluriquín, Sparre 14790 (S).

Guatemala: alta verapaz: Between Campur and Socoyo, Croat \& Folsom 33986 (F, MO), Standley 91929 (F); Cubilquitz, Steyermark 44397 (F); Pantín, Standley 70551 (F). IZABAL: Near Entre Ríos, Standley 72782 (F); S of Puerto Barrios, Croat 41805 (MO).

Honduras: ATLANTIDA: Lancetilla Valley, Chickering 82, 160 (MICH). copán: E of Copán, Croat 42528 (MO).

Mexico: Chiapas: N of Isthuatán, Croat 47867 (MO); SE of Palenque, Croat 40140 (MO).

Nicaragua: chontales: Above Cuapa, Stevens 3665 (MO). zelaya: Along Caño Majagua, Stevens 6997 (MO); SW of Colonia Naciones Unidas, Stevens 4985 (MO); Road to Colonia Yolania and Colonia La Esperanza, Stevens 6372 (MO); Road to Panua, Stevens 7797 (MO); Road from Siuna to Matagalpa, Stevens 7458 (MO).

PANAMA: BOCAS DEL TORO: Road between Almirante and Ojo del Agua, Croat 38217 (MO); Forest above Milla 7.5, Croat \& Porter 16242 (MO). CANAL zone: Pipeline Road, Croat 16699 (MO, SCZ). Colón: Santa Rita Ridge Road, Croat 34352 (MO); Between Tonosí and Río Indio, Croat 33534 (MO). DARIÉN: Santa Fe, Duke 14259 (MO). PANAMÁ: Vicinity of Cerro Campana, Croat 35964 (MO); El Llano-Cartí Road, Croat 25187 (AAU, MO, PMA); Logging roads along Río Pita, Duke 4746 (BH, GH, MO, US). SAN BLAS: Río Acla, Sugden 625 (MO).

25. Syngonium mauroanum Birdsey ex Bunting, Baileya 14:18. 1966. TYPE: Panama (exact locality unknown, cultivated at Amazon Gardens, Miami, Florida) Bunting 1441 (BH, holotype).

Juvenile plants with stems at first short, forming rosettes, becoming elongate, green; petioles $6-13 \mathrm{~cm}$ long, sheathed to the middle or somewhat above the middle, sharply 1-ribbed from the sheath to the blade; blades sagittate, the primary lateral veins and many secondary veins sunken above and beneath, the upper surface marked along the midrib and sometimes along the larger lateral veins with a discolorous band of gray or yellowish green, the anterior lobe ovate, acuminate, $5-16 \mathrm{~cm}$ long, the posterior lobes triangular to ovate, acute to rounded at the apex, 2-10 cm long. Adult plants with stems not glaucous, scandent, appressed to trees; internodes $1-12 \mathrm{~cm}$ long, $1-1.5 \mathrm{~cm}$ wide; petioles sheathed $1 / 2-$ $3 / 4$ their length; blades thin, subtrisect to usually trisect, rarely 5-segmented, medium green, matte above, slightly paler and matte beneath; leaflets free or sometimes confluent; median leaflet elliptic to ovate-elliptic, 12-21(-30) cm long, 3.5$10(-12) \mathrm{cm}$ wide, acuminate at the apex, obtuse to acute and attenuate at the base, the margin minutely undulate and sometimes appearing toothed on drying; lateral leaflets inequilateral, sometimes auriculate, the auricle usually conspicuously hastate, narrowly rounded at the apex; primary lateral veins 6-10 pairs, distributed throughout the blade (but thicker in the lower half of the blade), conspicuously sunken above, raised beneath; principal, secondary, tertiary and some quaternary veins sunken above, raised beneath, the reticulate veins clearly 

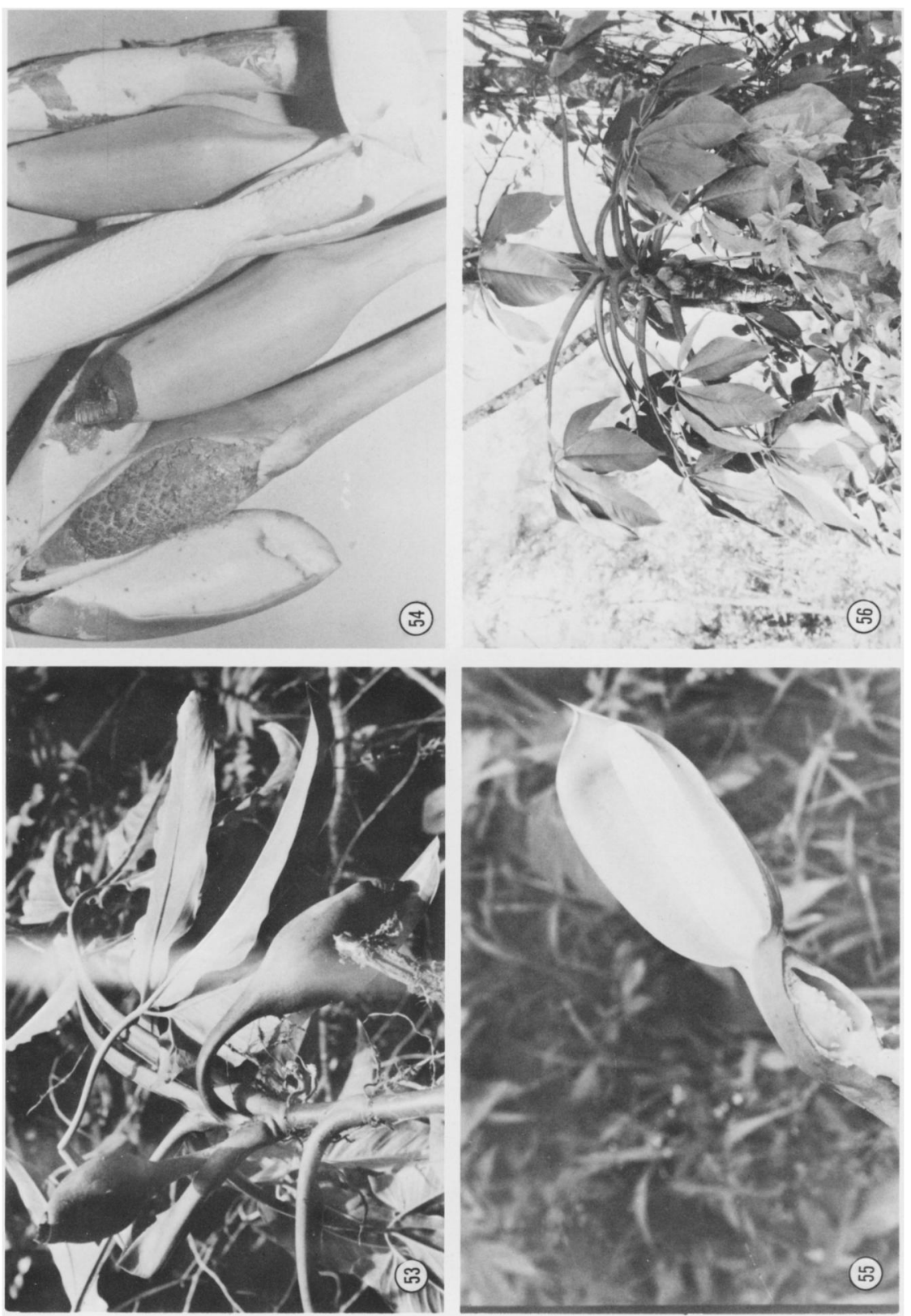

艺

ฉू

ธุे

$u \frac{\pi}{\nabla}$

ริ ป

这

sis

胥

i

$\dot{8} \mathrm{~s}$

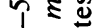
的要 㐫㫛 ! $\stackrel{\overline{-}}{\bar{x}}$ 远 \& 此 政 궁 政 흥 न के. 急 $\because \frac{5}{3}$ D 8 : 范 ธิ uे के $:=$ ระ) है 일 효 ป क्ष 宗专 के के กิ 1 कि 0

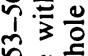

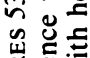
䟘 0 政 로를 
visible beneath. Inflorescences 1 or 2 per axil; peduncles $3.5-9 \mathrm{~cm}$ long and erect at anthesis, 8-14 cm long and pendent in fruit; spathe tube ellipsoid to narrowly ovoid, $3.5-5 \mathrm{~cm}$ long, $1.5-2.5 \mathrm{~cm}$ diam., green outside, dark violet purple inside; spathe blade ovate-elliptic, 6-8 cm long, $4-5 \mathrm{~cm}$ wide, acuminate, white; spadix $6.5-10 \mathrm{~cm}$ long, narrowly clavate; pistillate portion of the spadix ca. $1 \mathrm{~cm}$ long on the back side, ca. $1.5 \mathrm{~cm}$ long on the front side, the flowers irregularly rhombic at the apex, 2.3-3 mm diam., the stigma ca. $1.2 \mathrm{~mm}$ diam.; staminate portion of the spadix white, the sterile part ca. $1.5 \mathrm{~cm}$ long, the fertile part 5-6 cm long, the synandrium irregularly rounded to rhombic at the apex, the margin irregular, the apex not drying smooth, irregularly undulate. Infructescences $4.5-7.5 \mathrm{~cm}$ diam., red on the outside, violet purple within; syncarp brown, $4.5-6 \mathrm{~cm}$ long, $2.5-4 \mathrm{~cm}$ diam.; mesocarp white; seeds ovoid, 5-6 mm long, 4-5 mm diam., dark brown. Figs. 52, 57, 58.

Distribution: Syngonium mauroanum is known from Costa Rica and Panama in seasonally dry parts of tropical moist forest and especially from premontane moist forest life zones. It is an interesting testimony to the apparent accuracy of the Holdridge Life Zone Maps that the only collection from Costa Rica was also found in a narrow band of premontane moist forest in Guanacaste and that the species has been collected in the small isolated patch of premontane moist forest around Santa Fe in Veraguas. The species ranges from sea level to about $450 \mathrm{~m}$ elevation.

The species can be recognized by its usually hastate-lobed blades with distinctive prominent venation. It is not easily confused with any other species because of its relative isolation and narrow ecological range, but the species is closest to $S$. standleyanum, a species from premontane wet forest in Guanacaste Province, Costa Rica. That species often shows no sign of auricles on the lateral leaflets (a feature rarely exhibited by $S$. mauroanum) and has a densely papillate stem. Syngonium standleyanum may ultimately prove to be merely an ecological variant of this species.

Flowers are known from April to June and immature fruits in November and January.

Costa Rica: Puntarenas: N Puntarenas, Janzen 10731 (MO); Ujarrás de Buenos Aires, Pittier 11121 (US).

Panama: chiriquí: Near Remédios, Woodson et al. 1189 (F, GH, MO). Herrera: S of Ocú, Lewis et al. 1637 (GH, US). Los SANTOS: Vicinity of Tonosí, Croat 9763 (MO), Lewis et al. 1561 (GH, K, US), Lewis et al. 2193 (MO), Tyson et al. 2954 (MO, SCZ). PANAMÁ: Vicinity of Panama City, Bartlett \& Lasser 16708 (DUKE, MICH, MO). veraguas: Vicinity Santa Fe, Croat 27345, 34249 (MO); E edge of Escuela Agrícola Alto Piedra, Croat \& Folsom 33981 (MO); Vicinity of Santa $\mathrm{Fe}$, Nee 8038 (GH, MO), Luteyn 4048 (DUKE, MO); S of Santiago, Nee 8231 (MO), Tyson 6045 (SCZ).

26. Syngonium neglectum Schott, Bonplandia 7:163. 1859. TYPE: Mexico, Veracruz, near El Mirador (at Km 45 on road from Puente Nacional to Huatusco, $21 \mathrm{Km} \mathrm{E}$ of Huatusco), Liebmann s.n. (C) (type photo of Schott drawing 3212, NYBG 4315).

S. auritum (L.) Schott var. neglectum (Schott) Engler ex A. DC., Monogr. Phan. 2:294. 1879.

S. morelosense Matuda, Anales Inst. Biol. Univ. Nac. México 22:369. 1951[1952]. TYPE: Mexico, Morelos, Río Pollo near Cuernavaca, ca. $1500 \mathrm{~m}$, Matuda 25933 [MEXU, isotype; according to Birdsey (1955), the holotype originally designated by Matuda was lost in the mail]. 
S. occidentale Bunting, Gentes Herb. 9:370. TYPE: Mexico, Nayarit, at Km 15 on road from Tepic to Jalcocotán, $900 \mathrm{~m}$, Moore \& Bunting 8708 (BH, holotype; MEXU, US, isotypes).

Juvenile plants with stems not glaucous; petioles sheathed $2 / 3-4 / 5$ their length, 8-30 cm long; blades subsagittate to hastate, the anterior lobe ovate, acuminate at the apex, 9-14 cm long, 6-9 $\mathrm{cm}$ wide, the posterior lobes very unequal, to 10 $\mathrm{cm}$ long and $4 \mathrm{~cm}$ wide; intermediate blades with the posterior lobes increasingly pinched off, 3-lobed with conspicuous, broad auricles. Adult plants with stems not glaucous, 1.5-2.5 cm diam., shiny, olive green, becoming tan, short or elongated-creeping and firmly attached to trees; sap pale tan, copious; internodes 1.5$10 \mathrm{~cm}$ long on flowering parts, longer below, green when fresh, drying pale brown with many longitudinal folds; petioles $17-55 \mathrm{~cm}$ long, semiglossy, sometimes glaucous, slightly paler than the stem, sheathed $1 / 2-4 / 5$ their length, the sheath free ending at the apex (the free ending portion sometimes to $2.5 \mathrm{~cm}$ long), the portion between the sheath and the blade subterete, obtusely angled adaxially; blade firm, semiglossy, weakly coriaceous, sometimes semiglaucous on the upper surface, usually pedatisect with 3-7 leaflets, occasionally 9 , rarely 11 ; leaflets usually free or sometimes (especially the outer leaflets) confluent; median leaflet ovate to elliptic, rarely suborbicular, $14-38 \mathrm{~cm}$ long, 5-25 cm wide, acuminate at the apex with a small apiculum, obtuse to rounded and attenuate at the base, somewhat inequilateral; outermost leaflets often with slender, almost oblong auricles (these eventually pinching off and becoming widely separated as distinct leaflets); primary lateral veins 5-13 pairs, sunken above, prominently raised beneath; tertiary veins clearly visible on the lower surface. Inflorescences 1-3, usually 1 ; peduncles $7-15 \mathrm{~cm}$ long and erect at anthesis, $12-18 \mathrm{~cm}$ long and pendent in fruit; spathe tube suborbicular to ellipsoid, 4.5-6.5(-8) cm long, 4-6 $\mathrm{cm}$ diam., green outside, dark dull waxy red or sometimes violet purple inside; spathe blade orbicular to elliptic, acuminate at the apex, green becoming yellowish cream within (sometimes reddish at the base), sometimes creamy white on both sides, reflexed from the spadix at maturity, 9-15 cm long, 7-14 cm wide (when flattened); spadix sometimes curved sharply outward somewhat above the pistillate portion; pistillate portion of the spadix $1.4-3.9 \mathrm{~cm}$ long, $1.5-2.9 \mathrm{~cm}$ diam., yellowish green, the flowers 2(-3)-carpellate, the stigma bilobed; staminate portion of the spadix white, curved forward, 8-16 cm long, $1.5-3 \mathrm{~cm}$ diam., the flowers usually 4-androus (rarely more), the synandrium usually flat at the apex, usually irregularly 6-sided, ca. $5 \mathrm{~mm}$ long, $3 \mathrm{~mm}$ wide, the margins weakly sinuate. Infructescences orange to red, 6-9 $\mathrm{cm}$ long, 5-7 cm diam.; fruiting spadix brown, 5-7 cm long, 3-5 cm diam.; mesocarp fleshy, white; seeds grayish black to dark black, 6-10 mm long, 5-7 mm wide (Birdsey reports them as 10-13 $\mathrm{mm}$ long by $6-9 \mathrm{~mm}$ wide). Figs. 59, 60, 62, 63 .

Distribution: Syngonium neglectum is known only from Mexico but is widespread in that country, ranging from Tamaulipas to Chiapas on the Atlantic slope and from Nayarit to Chiapas on the Pacific slope. The range of life zones is uncertain, but the species is obviously quite variable ecologically and has been collected in both relatively dry and relatively wet areas. The species is most common at higher elevations in relatively dry situations. It occurs from near sea level (in the north of its range) or from near $350 \mathrm{~m}$ (in the south of its range) to $1700 \mathrm{~m}$ elevation. 
The species was considered a variety of $S$. auritum (a strictly West Indian species) by Engler \& Krause (1920). Syngonium auritum is distinguished by a spathe blade twice as long as the staminate portion of the spadix, whereas in $S$. neglectum the spathe blade and staminate portion of the spadix are of nearly equal length. Other characters which help to distinguish $S$. neglectum are the usually solitary inflorescences, and, especially, the size of the spathe and the staminate portion of the spadix, both of which are larger than for any other species.

Syngonium neglectum can be confused vegetatively with $S$. podophyllum where they occur together, although the latter species does not occur on the Pacific slope in Mexico and usually occurs at lower elevations, whereas $S$. neglectum frequently ranges above $1000 \mathrm{~m}$. Syngonium neglectum also lacks the glaucous stems usually present on Mexican plants of $S$. podophyllum.

Syngonium neglectum apparently flowers during the first half of the rainy season (June to September) and also at the beginning of the dry season.

Mexico: chiapas: E of Bochil, Ton 2577 (DS, F, MEXU, MICH); Between Chiapilla and San Lucas, Laughlin 278 (DS); Escuintla, Croat 43864 (MO), Matuda 20947 (MEXU), 17284 (F, MEXU); $\mathrm{N}$ of Ocozocoautla, Breedlove 25214 (DS), Croat 40586 (MO); Between Palenque and Bonampak, Croat 40220 (MO); NW of Solusi, Lathrop 6560 (DS). DISTRITo Federal: Tamasopo near Agua Buena, Rzedowski 10708 (MEXU). GUERrero: Below Tierra Colorada on road to Acapulco, Moore \& Bunting 8841 (BH). HIDALGo: Puerto del Zopilote, Moore 2708 (BH, GH); S of Tamazunchale, Barkley et al. 7278 (MEXU); Near Tonatico, Acevedo s.n. (MEXU). JALISCO: Vicinity of Autlán de Navarro, Moore \& Bunting 8735 (BH, MO); N of La Cuesta, McVaugh 21262 (MICH); SW of Pihuamo, McVaugh 24456, 24462 (MICH); S of Puerto Vallarta, Croat 45427 (MO); Quimixto, Mexia 1200 (F, GH, MICH, MO, NY, US). MARÍA MADRE ISLANDS: Tres María Group, Maltby 96 (US). MÉXICO: Temascaltepec, Hinton 3984 (GH, K), 3808 (G, K, NY). MICHOACÁN: S of Arteaga, Moore \& Bunting 8786 (BH, MO), 8792 (BH); Maguile, Emrick 129 (F). Morelos: Cuernavaca, Borgeau 1418 (P), Matuda 25983 (MEXU, MICH, US), 25933 (MEXU), Moore \& Bunting 8821 (BH); Oaxtepec, Harking 683 (MEXU), Matuda 26029 (MEXU, UC). NAYARIT: N of Compostela, McVaugh 16531 (MICH); Between Tepec and Jalcocotán, Croat 45243, 45336 (MO); Between Tepic and Jalcocotán, Moore \& Bunting 8708 (BH, MEXU, US); Between Mazatlán and Las Varas, McVaugh 19025 (MICH). oAXaCA: N of Ixhuatán, King 1997 (US); Betwen Pinotepa and Tlaxiaco, Croat 45803, 45815 (MO); Between Pochutla and Chacalapa, Hansen et al. 1543 (MO, WIS); NE of Valle Nacional, Thurm et al. 229 (UMO); El Vineda, Conzatti 3463 (MEXU, US). PUEBLA: Vicinity of Xicotepec de Juárez, Quintero 786 (MEXU). SAN LUIS POTOsí: Rowell et al. 17 M350 (F); N of Tamazunchale, Xolocotzi et al. 7644 (MEXU); NW of Tamazunchale, Croat 39282A (MO), Edwards 581 (F, MO), Hitchcock \& Stanford 6916 (US), Vines 334 (US). TABASco: Balancán, Finca La Esperanza, Calzada et al. 2653 (MO); Vicinity Comalcalco, West 2716 (WIS); Between Villahermosa and Teapa, Bravo et al. 110 (MEXU). TAmaulipas: S of Ciudad Victoria, Palmer 309 (F, GH, MO, NY, UC, US), Meyer \& Rogers (MO). Veracruz: Schnee V-VII (BH); Biological Station, Laguna Escondida, Hernández \& Vazquez 562 (MEXU); W of Coatzacoalcos, Croat 32740 (MO); Vicinity of Jalapa, Baez 127, 560 (F), Castillo \& Tapia 677 (MO), Hernández 205 (MEXU), Lot et al. 762 (MEXU), Ortega 336 (F, MO), Plunkett 27A (F); Vicinity Jesus Carranza, Nevling \& Gómez-Pompa 2558 (F); E of Minatitlán, Barkley \& Carr 36219 (GH); NW of Misantla, Bunting 1658 (US), Moore \& Bunting 8945 (BH, MO), Motzorongo, Smith 468 (MO); Between Orizaba and Córdoba, Rosas 405 (A, MEXU, O); Region of Orizaba, Borgeau 2416 (P); SW of Orizaba, Croat 39550 (MO); E of Papantla, Moore \& Bunting 8952 (BH); Biological Station at San Andrés Tuxtla, Calzada 85 (F, Jalapa); Vicinity San Andrés Tuxtla, Madison 1742, 1743 (GH), Martínez 2286 (F, Jalapa), Quintero 710 (MEXU); Between Sarabia and Cerro Quebrado, Gómez-Pompa \& Riba 262 (F); Vicinity of Tantoyuca, Chiang 10 (MEXU); Vicinity of Tepetzintla, Chiang 353 (MEXU); NE of Tihuatlán, Hansen et al. 1766 (MEXU, MICH, MO, WIS); SW of Tlapacoyan, Nevling \& Gómez-Pompa 1125 (MO, Jalapa); SW of Veracruz on Córdoba-Veracruz Road, Moore \& Bunting $8876(\mathrm{BH})$.

27a. Syngonium podophyllum Schott, Bot. Zeitung (Berlin) 85:1851. TYPE: MeXico (Schott drawings 3223 and 3226; NYBG Photos 4330 and 4329 respectively). 

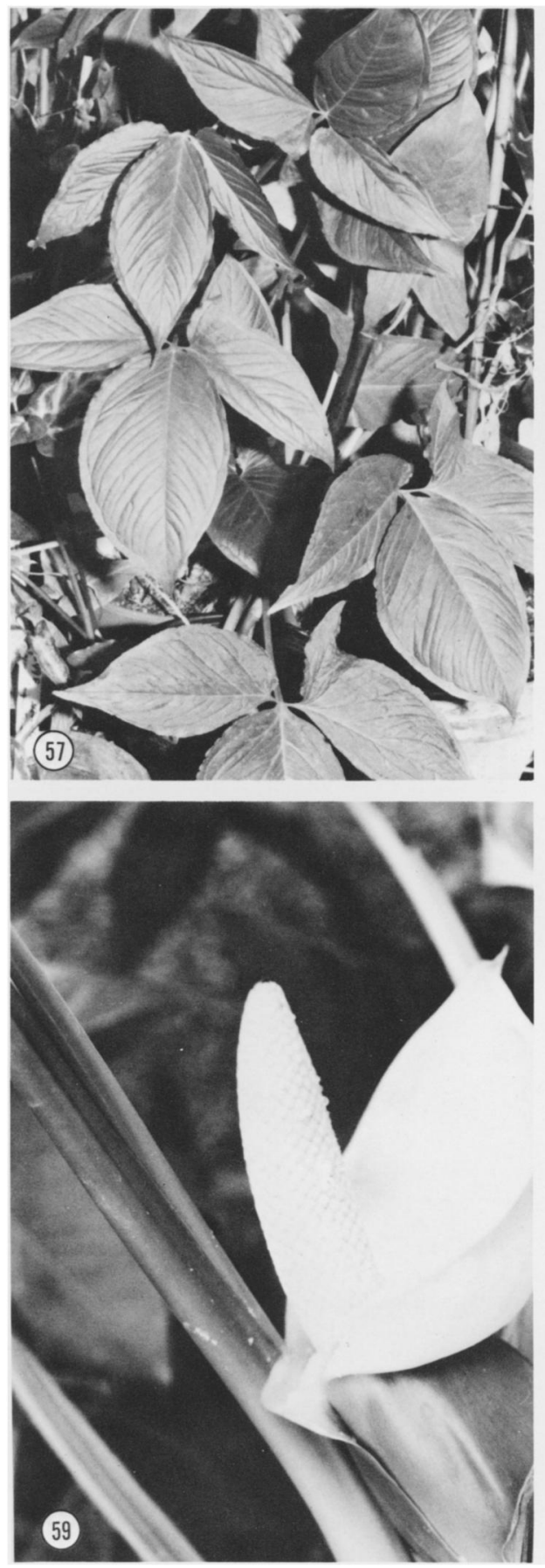

(60)
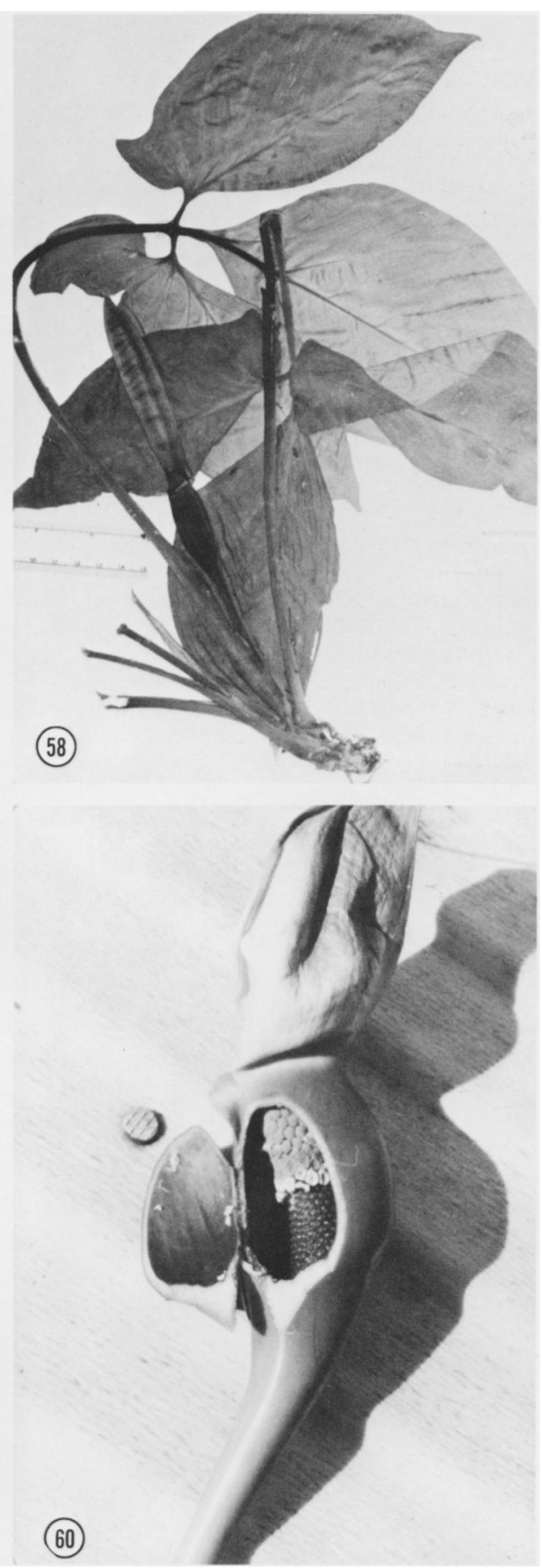

FIGURES 57-60.-57. Syngonium mauroanum, Croat 34249; adult blades $\left(\times^{1 / 4}\right)$.-58. S. mauroanum, Lewis et al. 1637; adult plant with inflorescences.-59. S. neglectum, Hiwan 1189; inflorescence at anthesis $\left(X^{5 / 12}\right)$. -60.S. neglectum, Hiwan 1189; inflorescence with cut-out showing pistillate flowers (base) and staminate flowers (above) $\left(X^{1 / 2}\right)$. 
Pothos auritus Willd. ex Schult., Mant. 3:301. 1827, non Syngonium auritum (L.) Schott. TYPE: Amer. Merid. Humboldt \& Bonpland (not seen).

Arum auritum Vell. non L., Fl. Flum. 9. tab. 113. 1827 (drawing only; no text). TYPE: Brazil (plate only).

Xanthosoma gracile Miq., Delect. Sem. Hort. Amstelodam. 1853. TYPE: Venezuela, Caracas, introduced into horticulture in Amsterdam.

Syngonium vellozianum Schott, Oersterr. Bot. Wochenbl. 4:418. 1854. TYPE: Brazil (Schott drawings 3239 and 3240; NYBG Photos 4318 and 4319 respectively).

S. ruizii Schott, Oesterr. Bot. Wochenbl. 4:148. 1854. TYPE: Peru (Schott drawing, NYBG Photo 4333).

S. gracile (Miq.) Schott, Syn. Aroid. 70.1856.

S. riedelianum Schott, Syn. Aroid. 70. 1856. TYPE: Brazil (based on Philodendron riedelianum hort. non Schott, not seen).

S. decipiens Schott, Syn. Aroid. 69. 1856. TYPE: Brazil, Ilheus (based on Caladium arboreum hort., Schott drawing 3200; NYBG Photo 4320 of collection of Erzherzog Maximillian 719).

S. poeppigii Schott, Syn. Aroid. 68. 1856. TYPE: Peru, Yurimaguas, Poeppig (Schott drawing 3226; NYBG Photo 4321) (see discussion).

S. affine Schott, Syn. Aroid. 67. 1856. TYPE: Surinam, Paramaribo, Wullschlagel 504 (Schott drawing 3192; NYBG Photo 4323).

S. willdenowii Schott, Syn. Aroid. 68. 1856. TYPE: Based on Pothos auritus Willd., Herb. No. 3104. fol. 1, Humboldt (P?, not seen).

S. xanthophilum Schott, Prodr. Syst. Aroid. 214. 1860. TYPE: Mexico (specimen at W destroyed); photo FM 29870; photo of Schott drawing, NYBG Photo 4335) (see discussion).

S. vellozianum Schott var. latilobum Engler, Fl. Bras. 3(2):130. 1878. TYPE: Brazil, Rio de Janeiro, Riedel.

S. vellozianum var. riedelianum (Schott) Engler, Fl. Bras. 3(2):130. 1878.

S. vellozianum var. decipiens (Schott) Engler, Fl. Bras. 3(2):130. 1878.

S. vellozianum var. poeppigii (Schott) Engler, Fl. Bras. 3(2):130. 1878.

S. amazonicum Engler, Pflanzenr. IV.23E (Heft 71):128. 1920. TYPE: Brazil, Amazonas, Rio Juruá, Ule 5614 (B, holotype).

S. podophyllum var. multisectum Engler, Pflanzenr. IV.23E (Heft 71):129. 1920. TYPE: Martinique, Duss 519 (not seen).

S. ternatum Gleason, Bull. Torrey Bot. Club 56:13. 1929. TYPE: Guyana, Waini River, De La Cruz 1288 (NY, holotype).

Juvenile plant with stems slightly glaucous; petioles sheathed $1 / 2-2 / 3$ their length; blades simple, cordate, 7-14 cm long, becoming sagittate or hastate, acuminate at the apex, the anterior lobe somewhat constricted at the base, the posterior lobes usually more or less triangular, directed downward or prominently outward; blades on climbing plants $12-27 \mathrm{~cm}$ long. Adult plants with stems sometimes glaucous; sap milky; internodes $2.8-14.5 \mathrm{~cm}$ long, $0.5-3.5 \mathrm{~cm}$ wide (dry); petioles $15-60 \mathrm{~cm}$ long, sometimes glaucous, sheathed $2 / 3$ their length (the sheath free-ending), rounded to obtusely angular above the sheath; blades pedatisect, the surface dark green above, pale below (sometimes glaucescent in South America); leaflets 3-11, united to free; lowermost leaflet variously auriculate at the base, the auricles oblong to oblong-elliptic to broadly elliptic; median leaflet obovate to broadly elliptic, abruptly acuminate at the apex, broadly or narrowly decurrent at the base, 16-38 cm long, 6-17 cm wide; rachis usually angular on blades with more than 3 segments; primary lateral veins 3-4(-7) pairs on the median leaflet, sunken above, prominently raised beneath; collective veins 2 or 3 ; tertiary veins all distinct. Inflorescences 4-11 per axil; peduncle sometimes glaucous somewhat compressed laterally, erect and usually less than $9 \mathrm{~cm}$ long at anthesis, pendent, to $13 \mathrm{~cm}$ long in fruit; spathe 9-11 cm long; spathe tube sometimes glaucous, narrowly ovoid to ellipsoid, $3-4 \mathrm{~cm}$ long, $1.8-2 \mathrm{~cm}$ diam., green inside and out; spathe blade greenish white to creamy white or sometimes yellow (in South America) (sometimes green outside and creamy white inside), 
6-7.5 $\mathrm{cm}$ long, 3-5 $\mathrm{cm}$ wide, long-cuspidate at the apex; pistillate portion of the spadix 1-2 cm long, 6-9 mm diam., greenish cream, the flowers irregularly (5$6(-7)$-sided, adherent, the stigma discoid-capitate, sometimes 2- or 3-lobed; staminate portion of the spadix 4-7 cm long, 7-15 mm diam., cream, the synandrium with anthers usually 4 , cross-shaped, $3.5-4 \mathrm{~mm}$ wide, partially or completely fused. Infructescences red to reddish orange or yellow (rarely brown) at maturity; syncarp ovoid, brownish, scruffy with darker brown flecks, 3-5.5(-7) cm long, $1.5-3.5 \mathrm{~cm}$ wide; seeds many, ovoid, 7-11 mm long, 5-7 mm wide, black or brown, enveloped in a soft, grayish, sweet, pulpy mesocarp. Figs. 64, 65, 69.

Distribution: Syngonium podophyllum is the most widespread and variable species in the genus, ranging from Mexico (states of San Luis Potosí and Veracruz) to the Guianas, Brazil, and Bolivia. It is found principally on the Atlantic slopes in Mexico but commonly extends to the Pacific slope in Guatemala, Costa Rica, and Panama. It ranges from sea level to usually less than $1000 \mathrm{~m}$ and is more abundant below $750 \mathrm{~m}$, especially between 100 and $500 \mathrm{~m}$. Ellenberg 3857 (Peru, Tingo María-Pucalpa) at $1510 \mathrm{~m}$ and Lehmann 5316 (Colombia, Río Negro in Andes of Popayán) at 1400-1600 $\mathrm{m}$ are both well out of the normal range of the species. They are sterile collections and doubtfully placed with $S$. podophyllum. In Central America it is most frequent in regions of tropical moist forest but also occurs in premontane wet forest. It is replaced by $S$. macrophyllum in tropical wet forest life zones.

Syngonium podophyllum and S. macrophyllum are often difficult to separate where they occur together in wetter parts of tropical moist forest and in premontane wet forest, but $S$. macrophyllum is usually distinguishable by its much larger vegetative and fertile parts, its smoother, thicker blades, which tend to dry brown rather than greenish as in $S$. podophyllum, and by its ovate-cordate juvenile blades.

The morphological variation in the species is great. Mexican plants may have up to 11 leaflets (usually 9), have leaflets often more widely separated and have stems, peduncles and spathe tubes glaucous, whereas Panamanian populations generally have mostly 3-5 (sometimes 7) leaflets with the lowermost leaflet often conspicuously auriculate.

Unusual variation is also represented in collections from Darién Province, Panama. Here the auricles of the lateral leaflets are frequently obovate and scarcely pinched-off rather than more or less oblong and usually conspicuously pinched-off as is typical of most Central American populations. These Darién populations most closely resemble typical material of what was previously considered $S$. vellozianum.

Infructescences in Mexico are commonly bright red whereas those in Panama and in South America are generally yellow to orange or red orange.

In Central America $S$. podophyllum is most closely related to and confused with $S$. angustatum. The two species occur together in similar habitats throughout much of their range in Central America, and according to Birdsey (1955) they may hybridize. (See the Key for characters used in separating the two species.) Syngonium podophyllum may also be confused with $S$. neglectum Schott in its vegetative condition. In the field $S$. podophyllum can be distinguished from $S$. neglectum by its glaucous stems. Although the species tends not to have glaucous 

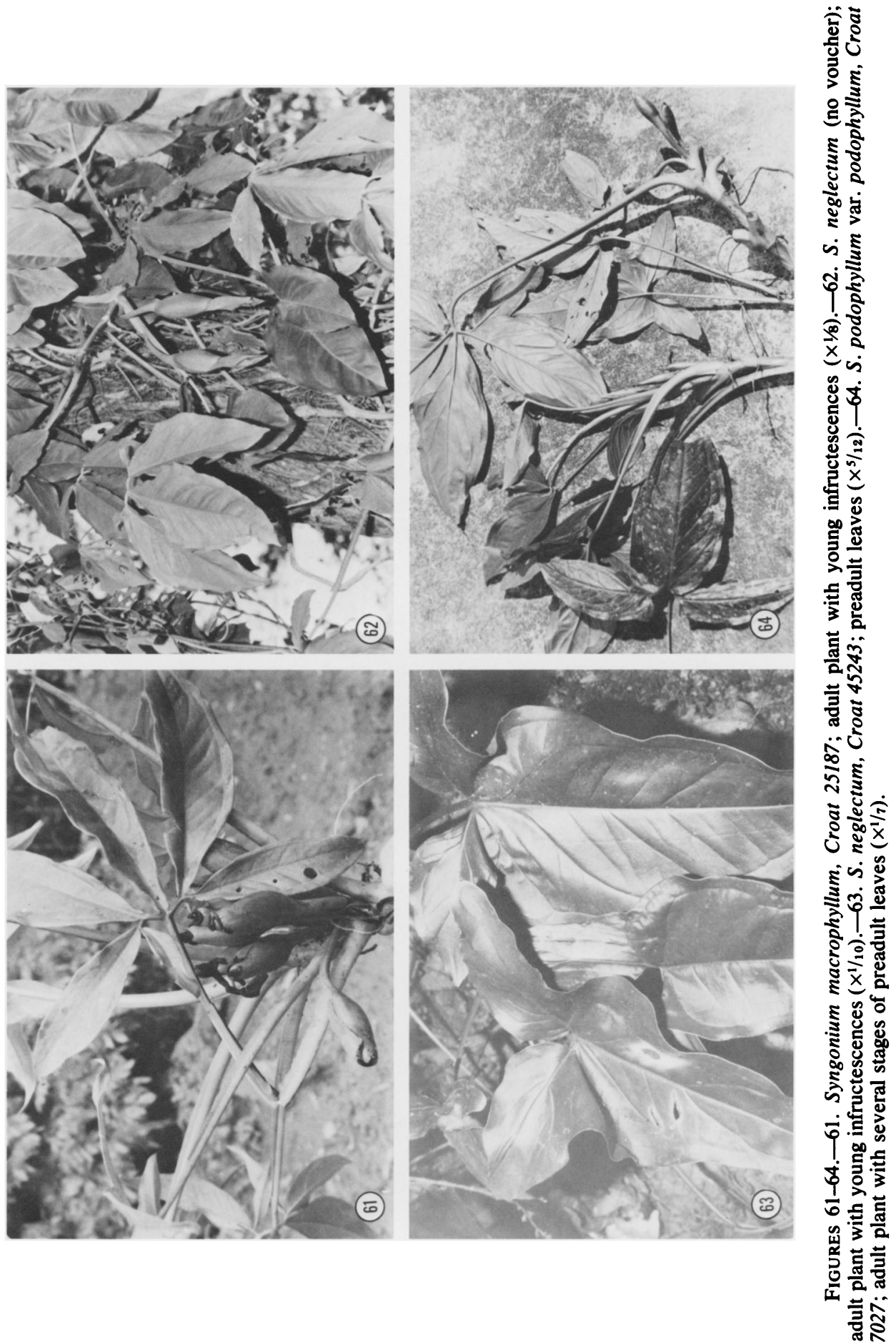
stems in the southern part of its range, there is no confusion with $S$. neglectum, which is restricted to Mexico.

The species is equally variable in South America. I have been unable to separate Central American material from S. vellozianum of South America. The widespread S. vellozianum was treated by Engler \& Krause (1920) as a distinct species based on its having leaflets with the leaf tissue united at the base. However, this is not always the case and the degree of separation of the leaf segments is in fact quite variable, ranging from leaves which have the segments closely united to leaves which have the segments relatively remote from one another. The same is true for the species in Central America, as I have already noted. Other variations in South American material of $S$. podophyllum involve the shape and size of the auricles on the lateral lobes. South American material generally has fewer leaflets (most commonly 3 distinct leaflets with the lateral leaflets conspicuously auriculate) and corresponds to the species in Panama and the lower part of Central America; however, it may have up to 5 distinct leaflets with a prominent "pinched-off" auricle, such as in material Engler and Krause called $S$. amazonicum. All of these characters are extremely variable and are not consistent in material from a single geographical area.

Another synonym of $S$. podophyllum is $S$. ternatum. Type material with this name, like that of $S$. yurimaguense, has poorly developed auricles on the lateral lobes. Considering the immense variability of $S$. podophyllum in a single population (or even on a single plant) there is no justification for maintaining these different leaf forms.

I believe that $S$. xanthophilum is a synonym of $S$. podophyllum. The description was of a sterile collection cultivated in Vienna. The collection as illustrated by Schott's painting (NYBG Photo 4335) represents an apparently juvenile plant. The leaves are remarkably similar to juvenile leaves of $S$. podophyllum. Further evidence that the Schott illustration represents a juvenile of $S$. podophyllum is that a photograph of an adult specimen of $S$. podophyllum was also later made at Vienna. This specimen seen in Field Museum Type Photo 29870 was perhaps collected from the same plant after it was more mature.

Mention should be made of the name $S$. auritum Poeppig which occurs in the literature. Poeppig (1845) prepared a description of $S$. auritum Schott with apparently no intention of considering it a new species. Schott (1856) described $S$. poeppigii saying that it was based on $S$. auritum Poeppig, a nonexistent name. Engler \& Krause (1920) in their revision of Syngonium included S. poeppigii Schott and $S$. auritum Poeppig in synonymy with $S$. vellozianum var. oblongisectum Engler thus perpetuating an error by Schott.

Although South American material of $S$. podophyllum may ultimately prove to consist of other subspecies or varieties with additional field work, enough is known at this time to recognize $S$. peliocladum as a variety of $S$. podophyllum. Variety peliocladum differs from the typical variety only in having tuberculate projections on the stems. Tom Ray (pers. comm.), who has studied populations in the field in Costa Rica, suspects that these projections may have no taxonomic significance whatever.

Syngonium podophyllum has been collected in flower and fruit throughout the year. 
Belize: Belize: N of Caves Branch Base Camp, Whitefoord 1080 (MO); Gracie Rock, Liesner \& Dwyer 1468 (F, GH, MO). CAYO: Along Sibun River, Croat 24866 (MO); Water hole near Vaca, Gentle 2446 (GH, MICH). TOLEDO: E of San Jose, Gentry 8133 (MO); Monkey River beyond falls, Gentle 3943 (GH, MICH).

Bolivia: la PAZ: Rurrenabaque, White s.n. (NY); Puerto Linores, Beck 1660 (MO); Basin of Río Bopi, Krukoff 10476 (F, GH, MO, NY). PANDo: Above Abuña, Prance et al. 6248 (NY, US).

BrazIL: No other location, Pires \& Santos 16463 (NY). ACrE: Between Mundurucus and Tatajuba, Maas et al. P12885 (K, NY), Steward et al. 12885 (US); Between Porangaba and Papagaio, Maas et al. P13132 (NY, US); NW of Cruzeiro do Sul, Prance et al. 2813 (NY); Trail to Rio Iaco, Prance et al. 7738 (NY, US); Vicinity of Campinas, Forero et al. 6350 (NY, US). AmAPÁ: Near mouth of Cricu River, Egler et al. 47443 (NY, US); At confluence of Rio Oiapoque, Irwin et al. 48040 (MO, NY, US). Amazonas: Vicinity Humaitá, Krukoff 6074 (GH, K, MO, NY, US), Prance et al. 3554, 8134 (NY); Juruá, Ule 5614 (B); Near Palmares, Krukoff 8055 (F, NY); Near Tabatingo, Prance et al. 16718 (NY, US). CEARÁ: Serra de Botavite, Ule 9000 (K). MARANHÃo: Island of São Luís, Froes 11740 (F). MATO GROSso: Vicinity of São Loucenço Mines, Prance et al. 8962 (K, NY, US); Vicinity of Jarú, Forero \& Wrigley 7111 (K, NY, US); Source of Jatuarana River, Krukoff 1573 (GH, K, NY). PARÁ: Prance \& Silva 58860 (F, GH, K, NY, US); Parque Indigena do Tumucumaque, Cavalcante 2377 (K, NY, US); Munc. Guaraquecaba, Hatschbach 18697 (US); Vicinity of Cachoeira, Prance \& Pennington 1798 (NY); Santarém, Silva \& Sousa 2249 (NY, US); Tucuruí, Silva et al. AS168 (US). PERNAMBUCO: Tapera, Tickel 3349 (US).

Colombia: amazonas: Near Loreto-Yacú River, Plowman et al. 2408 (F, GH, K), Schultes \& Black 8314 (US). Antioquia: Casabe, Renteria et al. 1940 (MO); Segovia Antioquia, Renteria et al. 1722 (MO). Bolívar: Vicinity Estrella, Curran 340 (US); Near Turbaco, Killip \& Smith 14660, 14661 (GH, NY, US). Boyacá: N of Bogotá, El Umbo, Lourance 688 (GH). Caldas: Aremnia, Pennell et al. 8660 (GH). CAUcA: Central Andes of Popayán, Lehman 5316 (K). chocó: Acandí, Forero 486 (MO); Hoya del Río San Juan, Forero et al. 3881 (MO); City of Mutis, Killip \& García 33462 (F, GH, US); Road to Palmar-Novita, Forero et al. 2413 (MO). META: E of Puerto López, Davidse \& Llanos 5486 (MO). PUtumayo: Vicinity of Santa Rosa, Plowman 2113, Schultes 3615 (GH); Puerto Limón, Schultes \& Cabrera 18713 (US). VALlE: Buenaventura, Lehman 5319 (F, K).

Costa Rica: alajuela: Vicinity of Bijagua, Croat 36324, 36374 (MO); Plains of San Carlos, Molina et al. 17671 (F, US). CARTAGo: W of Turrialba, Croat 36828 (MO). GUANACASTE: S of La Cruz, Williams \& Williams 24528 (F). Heredia: Near Río Puerto Viejo, Burger \& Stolze 5859 (F). limón: Jiménez, Smith 4980 (GH); SE of Limón, Croat 43172 (MO); S of Punta Cahuita, Croat 43203 (MO); S of Siguirres, Croat 43327 (MO). PUNTARENAS: Between Palmar Sur and Piedras Blancas, Croat 32918 (MO); Osa Peninsula, Rincón, Burger \& Stolze 5569 (F, US), Burger \& Liesner 7302 (F); N of Río Clara, Croat 32952 (MO).

ECUAdor: Bolívar: Charquiyacu, Solis 6129 (F). GUAYAS: Vicinity of Naranjito, Camp 3584A (NY). Los Ríos: Between Mocahi and Palenque, Dodson et al. 7110 (SEL); Río Palenque Biological Station, Dodson \& Ton 5304 (SEL, US). MARona-SANTIAgo: Gualaquiza, Sparre 19038 (S). NAPO: Between Baeza and Lago Agria, Croat 49513 (MO); Vicinity of Coca, Gentry 12526 (MO), HolmNielsen \& Jeppesen 831 (C, NY); Limoncocha, Mowbray 69930 (MO); SE of Tena, Grubb et al. 1555 (K, NY). PICHINCHA: El Recreo, Eggers 15131 (C).

El Salvador: Ahuachapán: Sierra de Apaneca, Standley 20157 (F). LA Libertad: SW of Santa Tecla, Carlson 154 (UC).

French Guiana: Camopi River, Oldeman \& Sastre 158 (US); Along l'Acarouany River, Sagot 936 (US)

Guatemala: Alta verapaz: Vicinity Cahabón, Cook \& Griggs 679 (US); Finca Sepacuite, Cook \& Griggs 31 (US); Along Río Icbolay, Steyermark 44748 (F); Latinta, Smith 1530 (US); Pampajché, Standley 70586, 70802, 70675 (F); Vicinity Tamahú, Croat 41492, 41523 (MO); W of Telemán, Croat 41535 (MO); Vicinity Chiquimula, Steyermark 30125 (F). IZABAL: La Libertad, Lundell 2603 (F), 3523, 3213 (US); S of Puerto Barrios, Croat 41875 (MO), LeDoux et al. 2103 (NY); Vicinity Quiriguá Viejo, Standley 23745 (US), Steyermark 38472 (F); Río Polochic, Smith 1532 (GH, K, US); Santo Tomás, Deam 6049 (GH, MICH, MO, US). PETÉN: Near Cancuén, Steyermark 45329 (MO), 45537 (F); Santa Elena, Ortiz 1820 (F, MICH). QUEZAltenango: Near Patzulín, Steyermark 33528 (F), Standley 86881, 86884, 86888, 86903 (F); Near Santa María de Jesús, Standley 68202 (F). SAN MARcos: Above San Rafael, Croat 40825, 40843 (MO). Sololá: Slopes of Volcán Atitlán, Steyermark 48017 (F, MO). SuchitepéQuez: Finca Alotenango, Standley 65015 (F); SW slopes of Volcán Zunil, Steyermark 35341 (F).

GuYANA: MAZARUNI-POTARo: Mazaruni River, Fanshawe 4783 (K). NORTHWEST: Waini River, Marabo Shortcut, LaCruz 1288 (NY, US). RUPUNUNI: Upper Rupununi River near Dadanawa, LaCruz 1469 (CM, F, GH, MO, NY, US); NW slopes of Kanoku Mountains, Smith 3547 (F, GH, K, NY, US).

Honduras: ATlántida: Vicinity La Ceiba, Yuncker et al. 8678 (GH, MO, UC, US); Lancetilla 
Valley, Pffeifer 2069 (US), Standley 52751, 53330, 54537, 56603, 56648 (F, US), 53486 (US). Yuncker 5091 (F), 5090 (MICH). copán: Below Copán Antigua, Barkley \& Hernández 40278 (GH); E of Copán, Croat 42512, 42524, 42527 (MO); Vicinity of ruins of Copán, Carlson 533 (F, UC). cORTÉs: $\mathrm{N}$ of Lago de Yojoa, Croat 42719 (MO). El CAYo: Vaca, Gentle 2599 (MICH). yoro: Quebrada Sica, Standley 53931 (US). SANTA BÁRBARA: San Pedro Sula, Thieme 5529 (US).

MeXico: No other location, Kenoyer 428 (F). CAMPECHE: Santa Leonor, Barlow 14-3 (MICH, WIS). CHIAPAS: Between Chiapilla and San Lucas, Laughlin 278 (F, MEXU); Escuintla, Matuda 16723 (GH), s.n. (7-12-47, 8-30-47) (MEXU), 17939, 20946 (MEXU); S of Isthuatán, Croat 47835 (CAS, MEXU, MO); N of Isthuatán, Croat 47870 (MO); SE of Mapastepec, Breedlove \& Thorne 30680 (MO); Munc. of Las Margaritas, on Guatemala Border, Breedlove \& McClintock 34088 (DS); Ocosingo, Breedlove 33950, 34463 (DS); N of Ocozocoautla, Breedlove 38214 (DS), Croat 40629, 40652 (MO); SW of Palenque, Croat 40318, 40338 (MO); N of Pichucalco, Croat 40083 (MO); NW of Pueblo Nuevo Solistahuacán, Croat 47799 (MO); WNW of Soyalo, Breedlove 37216 (DS); Between Tapachula and Unión Juárez, Croat 47204 (MO). GUERRERo: Acapulco and vicinity, Palmar 346 (F, GH, MEXU, MO, UC, US); E of Agua de Obispo, Crisman \& Willis 292 (MICH); NAYARIT: NW of Jalcacatlán, Croat 45306 (MO). OAXACA: Cahuapa River, Williams 8905 (F); Island of Malsaya, Quintero 657 (MEXU); Near Junction of Ismo Highway and Road to Matías Romero, Carlson $2193 a$ (F, MO); Tuxtepec, Chavelas \& Perry 237 (MEXU); Chavelas 278 (MEXU); Martínez \& Calderón 556 (GH, MEXU, UC, US); Ubrero, Williams 9290, 9525 (F); S of Valle Nacional, Croat 39721, 39737 (MO); NE of Valle Nacional, Moore \& Bunting 8909 (BH). PUEBLA: No other location, Bravo 520 (MEXU); Near María Andrea, Rzedowski 23379 (MICH). SAN LUIS POTosí: Palmer s.n. (US); NW of Huichihuayán, Croat 39247 (MO); NW of Tamazunchale, Croat 39282 (MO), Dunn \& Dunn 19152 (MO); Xilitla, Villar \& Hernández 7145 (MEXU). TABAsco: W of Cárdenas, Conrad et al. 2767 (MO); Road to del Golfo, Contu 176B (MEXU); Between Macuspana and El Carmen, Gilly \& Hernández 367 (MICH); Near Teapa, Matuda 37496 (MEXU). TAMAUliPAs: NNW of Gómez Farías, Martin 69 (MICH). Veracruz: Lot 637 (Jalapa); Near Boca del Río, Paxson et al. 17 M634 (F, MEXU); Campo Experimental de Hule, El Palmar Zongolica, Santos 2317, 3634 (MICH); Caña de las Perdidas, Chavelas et al. 2372 (MEXU); W of Catemaco, Quintero 1495 (MEXU); Cerro Gordo, Dorantes et al. 4261 (Jalapa); E of Coatzacoalcos, Croat 40061 (MO); Coatzacoalcos River, Williams 8420 (MICH); Between Conejo and Huatusco, Moore \& Bunting 8865 (BH, MO); Along Highway 185, N of border of Veracruz, Croat 40010 (MO); Hidalgotitlán, Vázquez 782 (F, Jalapa, MEXU); $\mathrm{S}$ of Highway between Córdoba and Veracruz, Croat 39616 (MO); S side of Laguna de Sontecomapau, Lot 1285 (F, GH, MEXU); Lake Catemaco, Calzada 54 (F); Road to La Palma and Balzapote, Calzada 2447 (F, Jalapa, MO); Las Choapas, Soto \& Horowitz 49 (Jalapa); N of Martínez de la Torre, Nevling \& Gómez-Pompa, 532 (GH, MEXU); NE of Minatitlán, King 1042 (MICH); District of Papantla, Kelly 156, 269 (BH); Between Papantla and Tajín, Moore \& Bunting 8955 (BH); Road to Playa Escondida, Breckon \& Breckon 2043 (MO); Rancho Tepellaw, Hernández s.n. (Jalapa); San Andrés Tuxtla, Dressler \& Jones 25 (GH), Kennedy \& Horvitz 3687 (F), Soto \& Horvitz 30 (F), Sousa 2107 (MEXU); San Francisco, Smith 1307 (F); E of San Pablo, Gutiérrez 9 (MEXU); Vicinity Santiago Tuxtla, Leija \& Garza 5418 (MEXU); On Road to Santecomapan, Moore \& Bunting 8934 (BH); W of Sayula de Alemán, Croat 40023 (MO); S of Tampico, Palmer 386 (GH, MO, US); YUGATÁN: Chichen Itza, Lundell \& Lundell 7506 (MEXU, MICH).

NiCARAgua: ChonTAles: Above Cuapa, Stevens 3694 (MO). Jinotega: SE of Yali, Croat 42934 (MO). zelaya: Alamicamba above Río Prinzapolca, Neill 3901 (MO); E of Siuna, Neill 4511 (MO).

PanAma: bocas Del TORO: Chiriquicito, Lewis et al. 2049 (GH, MO); Vicinity of Chiriquí Lagoon, Von Wedel 2616 (GH); Station Milla 7.5, Croat 38128 (MO). CANAL zone: Barro Colorado Island, Aviles 35 (F), Croat 5815, 7027, 7429, 8913, 10197, 11694, 16218, 20888 (MO), 10260, 11426, 11921 (F, MO), 10876 (F, MO, PMA, UC), 12558 (F, MO, SCZ), Foster 1939 (F, GH, MICH, PMA), Gentry 428 (MO), Hutchison \& Wright 2864 (UC), Shattuck 54 (F, GH, MO), Standley 40914 (US), Woodworth \& Vestal 585 (F, GH, MO); SE of Achiote, Gentry \& Nee 8663 (MO); Near Alhajuela, Dodge 16596 (MO); N of Frijoles, Standley 27451 (US); Vicinity Gamboa, Croat 32975 (MO), 32977 (PMA), Nee 7745 (US), Standley 28419 (US); Quebrada Bonita, Steyermark \& Allen 17211 (MO); S of Río Providencia, Tyson \& Blum 4003 (MO, SCZ); Near Summit Gardens, Dodge \& Hunter 8661 (MO). CHIRIQuí: Burica Peninsula, vicinity of Puerto Armuelles, Busey 466 (MO, NY), Croat 21936, 26704, 35055 (MO), Liesner 67 (F, MO), 504 (MO, US), Woodson \& Schery 930 (F, NY); Vicinity of Gualaca, Croat 49822 (MO); Vicinity of Palmas Bellas, Mori \& Kallunki 1971 (MO). colón: SW of Portobelo, Liesner 1080 (US); E of Portobelo, Liesner 1109 (MO, US); Vicinity of Portobelo and Nombre de Dios, Croat 33553, 33636, 49784 (MO); Vicinity Portobelo, Croat 49746 (MO). DARIÉN: Vicinity of gold mine at Caná, Croat 37599, 37659, 37676, 38034 (MO); Cerro Sapo, Hammel 1257 (MO); Vicinity El Real, Duke 5013 (MO, GH), Gentry \& Clewell 6917 (MO), Pittier 6568 (GH, US); Vicinity of Paya, Stern et al. 199 (GH, MO, US); Río Tuquesa, Le Clezio 188 (MO), PANAMÁ: Vicinity of Cerro Azul, Croat 11508 (MO); El Llano-Cartí Road, Croat 33776 (MO), Nee 10520 (US); Vicinity Río Majé, Croat 14524, 34438, 34658 (MO). 
Peru: amazonas: Río Cenepa, Ancuash 122, 1157, 1193 (MO), Berlin 371 (MO); S of Chávez Valdivia, Berlin 838 (MO). AYACUcho: Near Kimpitirique, Killip \& Smith 23007 (NY, US). HUÁNUco: Honoria, Schunke 1592 (F); Tingo María, Ellenberg 3826, 3857 (MO). JUNíN: N of La Merced, Killip \& Smith 23626 (NY, US). LoreTo: Iquitos, Killip \& Smith 27398, 27448 (NY, US), Martin et al. 1636 (F); La Victoria, Williams 2631 (F), 2782 (F, US); Leticia, Williams 3054 (F); Province Maynas, Diaz \& Jaramillo 9 (MO), Revilla 1087 (MO); N of Iquitos, Revilla 855 (MO); Río Huallaga, Williams 4986 (F, US), Croat 17855 (MO); Soledad on Río Itaya, Killip \& Smith 29680 (NY, US); NE of Yurimaguas, Killip \& Smith 27901 (US). MADRE DE DIOS: Parque Nacional de Manú, Foster \& Janson 5216 (F), Gentry et al. 26771 (MO), Terborgh 6624 (F); Tambopata, Gentry \& Revilla 16299 (F, MO, NY). SAN MARTIN: Mariscal Cáceres, Gentry et al. 26733 (MO), Schunke 38624932 (F, GH, MO, NY, US), 7711 (MO, US).

Puerto RICO: At Km 28.1 on Route 191 near Florida, Wagner 1003 (MICH).

SINGAPORE: No other location, Clemens 22553 (UC).

SurINAM: No other location, Samuels 175 (GH, K); Corantijn River, Boer \& Wessels 548 (A); Slopes of Hendriktop, Daniels 978 (US); Jodensavanne-Mapane creek area, Lindeman 4782 (F, MO, NY); Lucie River, Maguire et al. 53991 (NY), Prance et al. 54619 (F, K, NY, US), Prance et al. 55668 (NY); N of Paramaribo, Maguire \& Stahel 22800 (F, NY, US); Tibiti, Lanjouw \& Lindeman 1616 (K, NY, US).

TRINIDAD: Siparia Quarry, Britton \& Broadway 2795 (NY, US).

United STATES: Florida: Coral Gables, Kaplan 478 (UC); Madiera Beach, Anderson \& Mason 19328 (CM).

Venezuela: amazonas: Tencua, Colchester 2052 (K); Vicinity Mision de Santa María de los Guaicas, Steyermark 106164 (MO, VEN). APURE: San Camilo Forest Reserve, Steyermark et al. 101396 (MO, NY, VEN). BARINAS: Vicinity of Barinas, Bunting 2271 (MY); SW of Barinas, Smith 3292 (MY, VEN); Caño Barragán, Bunting 2257 (MY); Caparo Forest Reserve, Steyermark et al. 102051 (MO, VEN); Río Caparo, Liesner \& González 9413 (MO). Bolívar: S of Plateau of Nuria, Bunting \& Holmquist 4317 (MY); Vicinity of Salto Pará, Río Caura, Steyermark et al. 113104 (F, MO, US). Delta AmACuro: Sierra Imataca, Steyermark 87381 (F, K); Tucupita, Davidse \& González. 16548 (MO). MÉrIDA: Between San Cristóbal and El Vigía, Bunting 2403 (MY). TÁchIRA: Vicinity of San Cristóbal, Broadway 578 (US). Vicinity La Grita, Bunting 2483, 2491, 2497, 2500 (MY); E of Hacienda El Palmar, Steyermark et al. 120463 (MO). TRUjillo: La Ceiba, Williams 12661 (US). zUliA: S of Concha, Bunting 2774, 2788 (MY); Hacienda Las Chorros, Farrari \& Trujillo 1569 (MY); Sierra de Perijá, Steyermark \& Fernández 99633A (NY, US); SE of Mission of Los Angeles de Tocucu, Steyermark 99878 (US).

27b. Syngonium podophyllum Schott var. peliocladum (Schott) Croat, comb. nov.

S. peliocladum Schott, Prodr. Syst. Aroid. 202. 1860. TYPE: Costa Rica, Wendland (type destroyed, Schott drawings 3215, 3216; NYBG Photos 4327, 4328).

Juvenile plants with stems not glaucous, usually dark violet purple; petioles sheathed from $1 / 2$ to nearly the entire length; blades hastate to sagittate, the anterior lobe ovate, acuminate, the posterior lobes ovate to lanceolate, acute at the apex. Adult plants with stems not glaucous; internodes $0.4-1.5 \mathrm{~cm}$ diam., 1-20 $\mathrm{cm}$ long, usually densely covered with brownish projections; petioles $11-33 \mathrm{~cm}$ long, usually sheathed $1 / 2-4 / 5$ or more of their length, obtusely 1-ribbed adaxially; blades trisect to almost 5-lobed, mostly 16-33 cm long, often drying yellowish green; lateral leaflets free or confluent, usually conspicuously auriculate and usually nearly pinched-off to form a small lobe, the auricle directed at right angles to the axis of the lateral leaflets; median leaflet $14-25 \mathrm{~cm}$ long, ovate to elliptic, acuminate at the apex, acute to cuneate at the base; primary lateral veins 3-8 pairs, sunken above, raised beneath; collective veins 2 or 3 ; tertiary veins all clearly visible. Inflorescences usually 6-8 per axil; peduncles not glaucous, 3.5$11 \mathrm{~cm}$ long and erect at anthesis, $7-14 \mathrm{~cm}$ long and pendent in fruit; spathe tube ovoid to ellipsoid, usually not glaucous, $2-3 \mathrm{~cm}$ long, green inside and out; spathe blade greenish white to cream, 4-5.5 cm long, pistillate portion of the spadix 1$2 \mathrm{~cm}$ long; staminate portion of the spadix 4-6 cm long, the flowers similar to 
those of $S$. podophyllum. Infructescences yellow to orange, 4-5 cm long, 3-3.5 cm diam. Figs. 66, 70 .

Distribution: Syngonium podophyllum var. peliocladum is known from Costa Rica and Panama, principally on the Atlantic slope from sea level to ca. $1000 \mathrm{~m}$. In Panama it occurs only in Bocas del Toro Province. It occurs in tropical wet forest, premontane wet forest and wetter parts of tropical moist forest.

This variety is recognized by its trisect to almost 5-lobed leaves, usually several inflorescences, and stems which bear conspicuous tuberculate excrescences. Though previously considered distinct from $S$. podophyllum, it is distinguished from that species only by the stem excrescences, and the two taxa overlap in most of the characters previously used to separate them.

Flowering inflorescences are known from June through December. Immature fruits are found more or less throughout the year.

Costa Rica: cartago: Vicinity Chitaría, Solis 241 (F); Las Vueltas, Tucurrique, Tonduz 12891 (US). HEREdiA: Finca La Selva, Croat 44306 (MO); Near Puerto Viejo, Croat 35677 (MO). Limón: N of Bribri, Burger \& Antonio 10943 (F); Vicinity of Cairo, Standley \& Valerio s.n. (US); La Colombiana Farm, Standley 36975 (US); Vicinity Llanuras de Santa Clara, Smith 4980 (US); Between Siguirres and Río Pacuare, Burger \& Liesner 6931 (MO).

PANAMA: BOCAS DEL TORO: Above Almirante, Gentry 2745 (MO); W of Almirante, Croat 38225 (MO); Vicinity Changuinola, Croat 38082 (F, MO), Lewis et al. 954 (GH, K, MO, UC, US); Chiriquicito, Lewis et al. 2022 (MO); Vicinity of Chiriquí Lagoon, von Wedel 1025, 2616, 2765 (F, GH, MO); Between Quebrada Treglo and Puerto Palenque, Kirkbride \& Duke 533 (MO); Río Cricamola, between Finca St. Louis and Konkintoi, Woodson et al. 1915 (MO); Station Milla 7.5, Croat \& Porter 16305 (MO), Croat 38088, 38115 (MO); Water Valley, von Wedel 1545 (MO).

28. Syngonium salvadorense Schott, Oesterr. Bot. Z. 8:178. 1858. TYPE: El Salvador, Santa Anna, Wendland s.n. (P?, not seen; drawing of type by Schott 3231, NYBG Negative 4331 seen).

S. donnell-smithii Engler, Bot. Jahrb. Syst. 37:141. 1905. LECTOTYPE: Guatemala, Escuintla, Escuintla, $1100 \mathrm{ft}$, Donnell Smith 2782 (B, lectotype; M, isolectotype)

Juvenile plants with stems glaucous; internodes 5-20 cm long, less than $1 \mathrm{~cm}$ thick; petioles 12-25 cm long, glaucous, sheathed beyond the middle (sometimes more than $4 / 5$ their length); blades usually hastate, sometimes sagittate, $9-19 \mathrm{~cm}$ long, 5.5-11 cm wide, the anterior lobe equilateral or inequilateral, often constricted at the base, the posterior lobes inequilateral, usually longer than broad; intermediate blades becoming larger, more conspicuously hastate-lobed, mostly 20-30 cm long, the lobes ovate to broadly ovate, directed markedly outward, eventually becoming pinched off. Adult plants with stems glaucous, frequently scandent; internodes 3-14 cm long, 1-2 cm diam., olive green when young, the periderm tan, thin and cracking; petioles slightly paler than the stems, $18-42 \mathrm{~cm}$ long, sheathed $1 / 2_{2}-4 / 5$ their length, obtusely ribbed above the sheath, the sheath free-ending and acute at the apex; blades trisect to sub-5-sect, the lobes usually confluent to almost free, the median lobe broadly ovate to ovate-elliptic, 14-28 $\mathrm{cm}$ long, 8-18 $\mathrm{cm}$ wide, acuminate at the apex, rounded at the base, the lateral lobes ovate, unequal, usually not auriculate, sometimes with hastate auricles, rarely the auricles nearly pinching off to form a nearly 5-lobed blade; primary lateral veins 2-5 pairs, mostly arising in the lower half of the blade, slightly sunken on the upper surface, raised beneath; tertiary veins clearly visible on the 

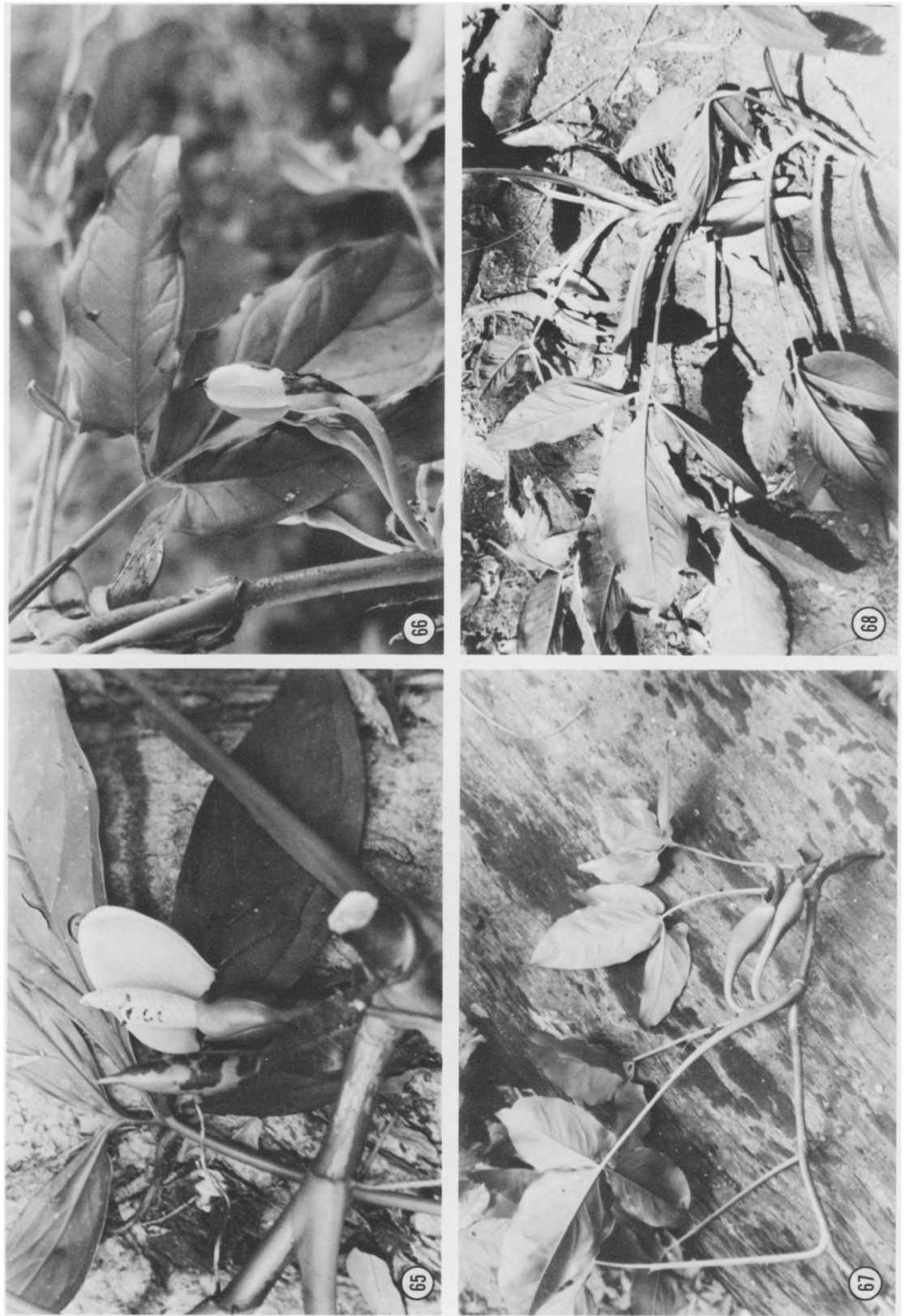

$\times$

票

ष्ठ

主孪

㐘

要

ส

के

ป

或

일

.

뒤

3 in

츨

문

$\pm \cdot \frac{\infty}{5} . \Xi$

蛋

$\ddot{8} \overline{\mathrm{\sigma}}$

宊

$\checkmark 8$

政

了要

은 =

․ㅡㄹ

든

는

동

흐

(ब)

₹

今.

3ิ

ธิ

용

हon

竎

政

के

ที

128

$\infty$

政

ऽ 5

悹

ड.

正

is. 
lower surface. Inflorescences 1 or 2 per axil; peduncles $9-18 \mathrm{~cm}$ long and more or less erect in flower, 9-25 cm long and pendent in fruit; spathe tube ellipsoid, 4-5 cm long, 3-4 cm diam., green outside, the inside reddish at the base, greenish near the apex; spathe blade broadly ovate, 7-10 cm long, 4-5 cm wide, greenish outside, the inside white, abruptly cuspidate at the apex; pistillate portion of the spadix 1.5-2.5 cm long, 1-1.5 cm diam., greenish, the flowers with stigmas bilabiate; the staminate portion of the spadix white, clavate, 5-7 cm long, 1-1.5 $\mathrm{cm}$ diam., the synandrium irregularly 6-sided, flat at the apex with no sign of fusion, the margins weakly scalloped. Infructescences red orange to red, often massive, 9-12 cm long, 6-8 cm diam.; syncarp brown, to $8 \mathrm{~cm}$ long and $5 \mathrm{~cm}$ diam.; mesocarp sweet, fleshy, white; seeds black, ovoid-ellipsoid, 8-12 mm long, 4-6 mm diam. Fig. 67.

Distribution: Syngonium salvadorense ranges from southwestern Mexico (Chiapas) along the western coast of Guatemala to El Salvador. It occurs principally in tropical moist forest from sea level to $700 \mathrm{~m}$.

The species is not confused with any other but resembles $S$. neglectum in having large and often solitary inflorescences.

The species is a conspicuous plant in disturbed areas and often grows in great profusion, to the exclusion of most other epiphytic plant species, on the shade trees in coffee plantations in Guatemala.

Flowering inflorescences have been found in February and August. Fruits are mature mostly in July and August.

El Salvador: ahuachapán: NE of San Francisco Menéndez, Croat 42074 (MO), Padella 324 (US). SAN SALVAdOR: No other location, Calderón 924 (US); Vicinity of San Salvador, Renson 268 (NY, US); Tonacatepeque, Calderón 2273 (GH, US). sonsonATE: Vicinity of Sonsonate, Standley 22320, 22337 (GH, NY, US). SAN vincente: Vicinity of San Vincente, Standley \& Padella 3745, 3746, $3798(\mathrm{~F})$.

Guatemala: escuintla: No other location, Smith 2782, 2783, 2238 (B, NY, US); Escuintla, Standley 89211, 89311 (F); Finca Cuyuta, Smith 2235, 2238 (US); San José, Standley 64081, 64200 (F); Santa Lucía Cotzumalguapa, Kellerman 5266 (MEXU, US), Standley 63442 (F). RETALHULUE: Finca Las Delicias near Retalhulue, Standley 88044 (F); Vicinity of Retalhulue, Standley 66788, $87259,87294,87400,88278$ (F); San Felipe, Smith 2781 (US); SANTA ROSa: Cuilapa, Standley 77982 (F); Near Guazacapán, Standley 78640, 78965, 78974, 79038, 79055 (F); N of Las Cerritos, Standley 79562, 79579a (F). SUCHITEPÉQUEZ: Vicinity of Mazatenango, Croat 43758 (MO), Standley 88865 (F), White 5184 (F, MICH); Vicinity of Tiquisate, Steyermark 47707 (F, US).

MeXICo: ChIAPAS: Vicinity of Escuintla, Croat 43867, 47533 (MO), Matuda 16512 (F, MEXU, MICH, NY), 17695, 17881 (DS, F, MEXU, NY), 17792 (DS, MEXU), 17858, 17937, 17970 (MEXU), 18715 (MEXU, US), 37675 (DS); Vicinity of Finca Prusia, Breedlove 38652 (DS); NW of Huixtla, Breedlove \& Smith 22534 (DS); NE of Huixtla, Breedlove 30921 (DS); Pueblo Nuevo Solistahuacán, Matuda 17831 (MEXU); SE of Tonalá, Breedlove 25638 (DS); Vicinity of Tuxtla Gutiérrez, Breedlove 37771 (DS).

29. Syngonium sparreorum Croat, sp. nov. TYPE: Ecuador, Cotopaxi, Río Guapara, ca. $20 \mathrm{~km} \mathrm{NW}$ of El Corazón, monsoon forest, ca. $250 \mathrm{~m}$, Sparre 17193 (S, holotype).

Caudex 1-1.5 cm diam.; lamina trisecta aut 5-pedatisecta; petiolus 29-47 cm longus, ad 1/2-2/3 longitudinalis usque anguste vaginatus; lamina elliptica ad obovata-elliptica, segmentum medium equalis, segmenta lateralia inaequalia leviter, venis lateralibus utroque latere 10-12, fere rectangularibus. Inflorescentiae 2; pedunculus $7-10 \mathrm{~cm}$ longus, gracilis; spathae tubus $5-6 \mathrm{~cm}$ longus, oblongusovoideus, $1.5-2 \mathrm{~cm}$ diam.; spathae lamina 7.5-8.5 $\mathrm{cm}$ longa, ovata, apice cuspidate; spadix parte feminea 10-12 mm longa, parte mascula spadicis 6-7.5 cm longa; infructescentia pendula, spathae tubo atropurpureo; spadix ad $9.5 \mathrm{~cm}$ longa; semina atera, ca. $7 \mathrm{~mm}$ longa. 
Hemiepiphytic vine; stem 1-1.5 cm diam., drying pale brown; internodes elongate, 6-7 cm long near the apex; petioles $29-47 \mathrm{~cm}$ long, narrowly sheathed $1 / 2-$ $2 / 3$ their length, to $7.5-10 \mathrm{~cm}$ from the apex, the apex of the sheath slightly free from the petiole; blades trisect to 5-pedatisect, the leaflets distinctly free; median leaflet equilateral, elliptic to obovate-elliptic, abruptly acuminate at the apex, cuneate to acute at the base, 17-28 cm long, 9.5-12 cm wide, the leaf tissue decurrent to near the base, the lateral leaflets slightly inequilateral, obtuse to acuminate at the apex, 14-25 cm long, 5.3-9 cm wide, the base narrowly acute on the inner side, obtuse to rounded or conspicuously auriculate on the outer side, the auricles conspicuously constricted at their base; petiolules 7-17 mm long, sometimes free; outermost leaflets nearly oblong to ovate-oblong, $8-10 \mathrm{~cm}$ long, 2.7-7 cm wide, narrowly rounded to acute at the apex, the blade surfaces drying yellowish brown; primary lateral veins mostly 10-12 pairs, mostly joining the midrib at a nearly $90^{\circ}$ angle, curved to the collective vein; collective vein 3$10 \mathrm{~mm}$ from the margin, almost straight or conspicuously loop-connecting with the primary lateral veins; reticulate veins very fine and close but clearly visible on dried material. Inflorescences 2 in uppermost leaf axil, erect; prophylls ca. 15 $\mathrm{cm}$ long, obtuse at the apex, apparently caducous; peduncles $7-10 \mathrm{~cm}$ long, slender, 2-4 mm diam. (dried); spathe tube 5-6 cm long, oblong-ovoid, $1.5-2 \mathrm{~cm}$ diam.; spathe blade $7.5-8.5 \mathrm{~cm}$ long, ovate when open, cuspidate at the apex, thinly coriaceous, drying brown, soon caducous; pistillate portion of the spadix 10-12 mm long, $5 \mathrm{~mm}$ diam. (dried), the flowers ca. $1.5 \mathrm{~mm}$ diam., in 5 or 6 spirals, the stigmas raised, ca. $1 \mathrm{~mm}$ diam.; staminate portion of the spadix 6-7.5 $\mathrm{cm}$ long, clavate, ca. $1 \mathrm{~cm}$ diam. in the widest part, conspicuously constricted just above the sterile staminate flowers, the fertile staminate flowers ca. $3 \mathrm{~mm}$ long, rounded to irregularly 4-6-sided, the apex of the synandrium truncate, entire, the margins minutely crenulate; sterile staminate portion of the spadix ca. $14 \mathrm{~mm}$ long, ca. $8 \mathrm{~mm}$ diam. the sterile staminate flowers ca. $2.5 \mathrm{~mm}$ long, 1.5 $3 \mathrm{~mm}$ diam., mostly free from one another, rarely fused. Infructescences pendent; peduncle to $13 \mathrm{~cm}$ long, to $7 \mathrm{~mm}$ diam.; spathe tube oblong-ellipsoid, gradually tapered to both ends, to $13 \mathrm{~cm}$ long and $5 \mathrm{~cm}$ diam., apparently dark violet purple; fruiting spadix oblong-ovoid, to $9.5 \mathrm{~cm}$ long on the front side, $6.5 \mathrm{~cm}$ long on the back side, ca. $4.5 \mathrm{~cm}$ diam.; seeds black, oblong-ovoid ca. $7 \mathrm{~mm}$ long. Figs. 71 , 72 .

Distribution: The species is known only from the type locality on the Pacific slope of northcentral Ecuador.

It is named in honor of the co-author of the Flora of Ecuador, Baron Benkt Sparre, who has made the only collections of the species. Syngonium sparreorum is probably closest to $S$. gentryanum from Huánuco Department, Peru, but differs in being 5-pedatisect in part and in having the primary lateral veins of the leaflets more numerous and joining the midrib at a nearly $90^{\circ}$ angle.

Flowers and immature fruits were found in June.

Ecuador: cotopaxi: Río Guapara NW of El Corazón, 250 m, Sparre 17096, 17101, 17193, 17212,17297 (S).

30. Syngonium standleyanum Bunting, Baileya 14:21. 1966. TYPE: Costa Rica, Guanacaste, El Arenal, 485-800 m, Standley \& Valerio 45248 (US-1254001, holotype). 

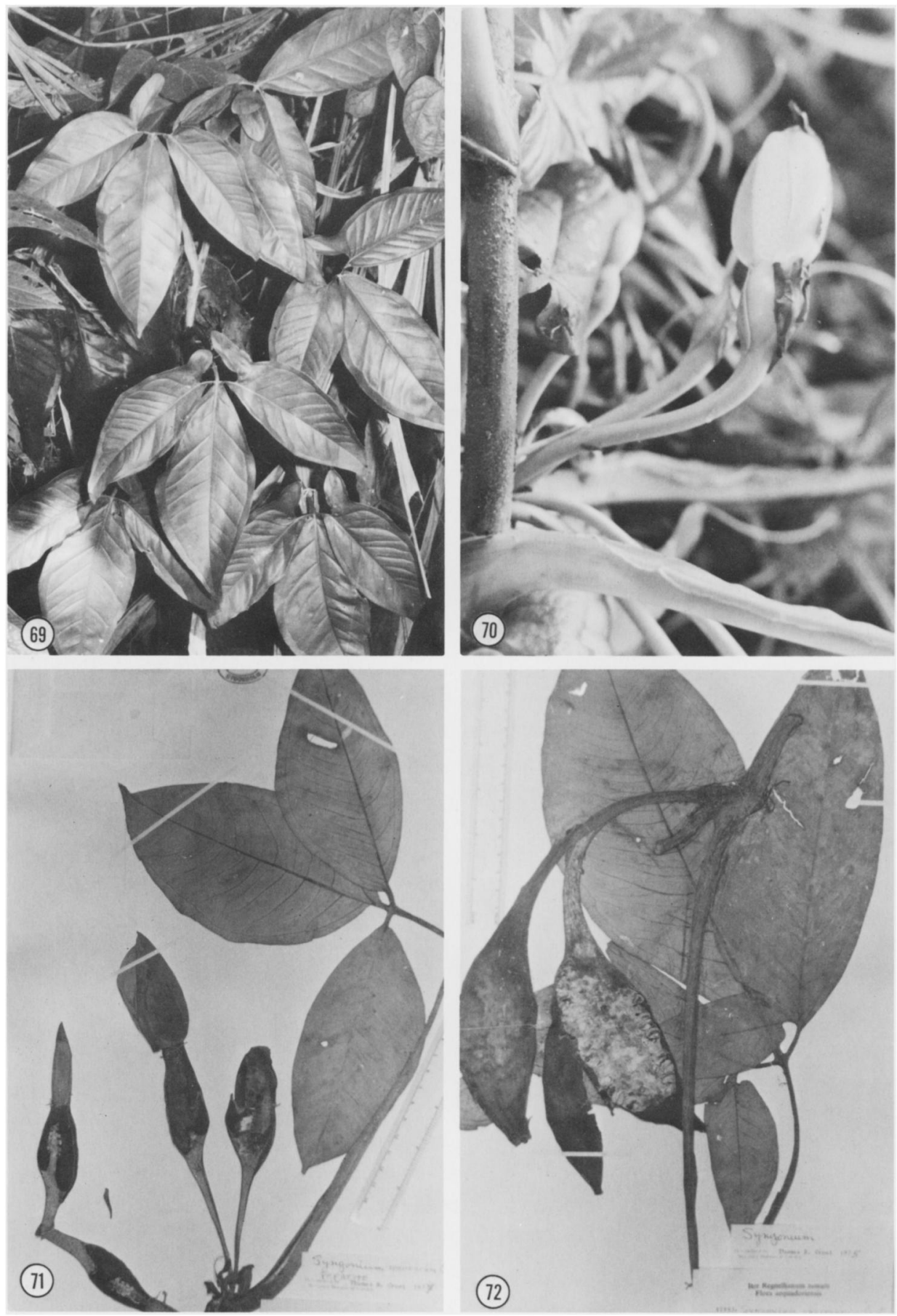

FIgURES 69-72.-69. Syngonium podophyllum var. podophyllum, Croat 45306; adult leaves $(\times 1 / 8) .-70$. S. podophyllum var. peliocladum, Croat 38082 ; adult stem showing projections and open inflorescence $\left(\times^{2 / 5}\right)$.- -71. S. sparreorum, Sparre 17297; adult blade and inflorescences.-72. S. sparreorum, Sparre 17193; adult blade and infructescences. 
Juvenile plants with scandent stems, not glaucous; internodes $2.3-6.5 \mathrm{~cm}$ long; petioles sheathed more than $4 / 5$ their length, 4-12 cm long; blades elliptic, inequilaterally acuminate at the apex, 4-10 cm long, 2-4 cm wide; intermediate leaves elliptic to oblong or lanceolate, subhastate or cordate at the base. Adult plants with stems green, not glaucous, densely and minutely papillate, drying pale brown with longitudinal wrinkles; internodes $3-12 \mathrm{~cm}$ long, less than $1 \mathrm{~cm}$ diam.; petioles $25-35 \mathrm{~cm}$ long, sheathed $2 / 3$ or nearly the full length $(1.5-9 \mathrm{~cm}$ from the apex), the portion above the sheath acutely angled on the upper side; blades trisect, the leaflets free; median leaflet slightly to very inequilateral, elliptic to oblong, 18-28 cm long, $6.5-12 \mathrm{~cm}$ wide, acuminate and mucronate at the apex, acute and attenuate at the base; lateral leaflets elliptic-oblong, 11-24 cm long, slightly if at all more inequilateral than the median leaflet, acute-cuneate on the inner edge at the base, obtuse to rounded or slightly auricled on the outer edge at the base; petiolule 5-15 mm long; primary lateral veins ca. 6 pairs, sunken above, raised beneath; smaller veins clearly visible (at least on drying). Inflorescences solitary; peduncle $4.5-5.2 \mathrm{~cm}$ long, less than $4 \mathrm{~cm}$ diam. on drying; spathe $11.5 \mathrm{~cm}$ long; spathe tube green, $4.5-5 \mathrm{~cm}$ long, ca. $3 \mathrm{~cm}$ diam., fusiform-cylindroid; spathe blade white, ovate-elliptic, $6.2-7 \mathrm{~cm}$ long, ca. $2.5 \mathrm{~cm}$ diam. (closed), ca. $3.5 \mathrm{~cm}$ wide (open), acuminate at the apex, $2.8 \mathrm{~cm}$ longer than the spadix; spadix $8.1 \mathrm{~cm}$ long; staminate portion of the spadix clavate, creamy white, ca. $6 \mathrm{~cm}$ long. Infructescences unknown.

Distribution: Syngonium standleyanum ranges from Honduras to Costa Rica on the Caribbean slope. In Costa Rica it occurs in tropical wet forest and premontane wet forest at elevations from near sea level to about $500 \mathrm{~m}$.

Bunting (1966) reported that the species could be distinguished by the matte upper blade surfaces, deeply impressed primary lateral veins, and the shape of the leaf blade. In addition the densely papillate stem is characteristic. The species is perhaps closest to $S$. mauroanum but that species lacks the densely papillate stems, usually has more prominently hastate posterior lobes, and occurs in tropical moist or premontane moist forest.

Birdsey (1955) proposed a new species to be called S. stenophyllum but the name was never published. It was to have been based on Donnell-Smith 6807 (US-936784) and Birdsey 335 (UC, US). I have seen the former and it is $S$. standleyanum.

Costa Rica: guanacaste: El Arenal, Standley \& Valerio 45248 (US); Vicinity of Tilarán, Standley \& Valerio 44313 (US). Limón: La Concepción, Smith 6807 (US). PUNTARENAS: Osa Peninsula, Parque Corcovado, Ray 3, 17, 18, 19, 44 (GH).

Honduras: Zelaya: In forest behind Bluefields, Bunting \& Licht 1250 (K, US).

31. Syngonium triphyllum Birdsey ex Croat, sp. nov. TYPE: Costa Rica, Heredia, near Puerto Viejo along the Río Sucio, $20 \mathrm{~m}$, Croat 35675 (MO-2381577, holotype).

Caudex 1-2.5 cm diam.; lamina plerumque trisecta, saepe basi auricula conspicua spathulata; petiolus $11-50 \mathrm{~cm}$ longus, ad $2 / 3-4 / 5$ longitudinalis usque vaginatus, apice acute triangulari; lamina media ovata ad oblonga-elliptica aut elliptica, aequilatera, 17-32 cm longa, lamina lateralis ovataelliptica ad elliptica, fere aequilatera aut inaequilaterissima et basi auriculata, venis conspicue depressis. Inflorescentiae 1-3(-5); pedunculus 5-7 cm longus; spathae tubus anguste ellipsoideus, 4.5- 
$6 \mathrm{~cm}$ longus, 2-2.5 cm diam., intra viridis pallide, extra rubus; spathae lamina oblonga-elliptica ad oblonga, albida, 8-9 cm longa, cucullata; spadix parte feminea 1.9-2.5 cm longa, stigmate sessili, cupulato.

Juvenile plants at first with short internodes ( $5 \mathrm{~mm}$ or less), becoming scandent, not glaucous, green to greenish brown, turning brown with age; internodes to $17 \mathrm{~cm}$ long; petioles sheathed $4 / 5$ or nearly their entire length, less than $10 \mathrm{~cm}$ long, the sheath with the margin crisped; blades inequilateral, elliptic, acuminate at the apex, acute to obtuse and often inequilateral at the base, sometimes weakly cordate, $6-23 \mathrm{~cm}$ long; $3-9 \mathrm{~cm}$ wide. Intermediate plants with petioles $14-28 \mathrm{~cm}$ long; blades entire and elliptic to oblong-elliptic or ovate-elliptic or becoming auricle-lobed at the base, the auricles held parallel to the petiole, in later stages becoming more trisect, the lobes oblong-elliptic, directed at nearly right angles to the midrib. Adult plants with stems not glaucous, sometimes branched; internodes to $9 \mathrm{~cm}$ long, to $2.5-3.5 \mathrm{~cm}$ long on flowering portions, $1-2.5 \mathrm{~cm}$ diam., brown, matte, sometimes drying flaky, sometimes with sharp longitudinal wrinkles; petioles $11-50 \mathrm{~cm}$ long, sheathed $2 / 3-4 / 5$ their length or more, the unsheathed portion sharply triangular with the lateral margins sharply raised; blades usually trisect but frequently with a conspicuous spatulate auricle at the base, the auricle sometimes to $15 \mathrm{~cm}$ long, the blade thus appearing almost 5-pedatisect; leaflets free, semiglossy above, dark green, drying dark, the lower surface slightly paler; median leaflet ovate to elliptic or oblong-elliptic, equilateral or nearly so, 17-32 $\mathrm{cm}$ long, $6-14 \mathrm{~cm}$ wide, short-acuminate at the apex, cuneate or obtuse at the base; lateral leaflets of well-developed blades $15-28 \mathrm{~cm}$ long, 4-11 cm wide, ovate-elliptic to elliptic, nearly equilateral to very inequilateral and variously auriculate at the base, the auricles oblong to spatulate to oblong-elliptic, $6-16 \mathrm{~cm}$ long; primary lateral veins $10-16$ pairs, scarcely more prominent than the interprimary veins, the latter numerous, the primary, major secondary veins and collective veins prominently sunken, prominently raised on the lower surface, the smaller veins clearly visible when fresh; reticulate veins often very close and fine on drying, the collective veins $3-12 \mathrm{~cm}$ from the margin, moderately straight or broadly arching between the primary lateral veins. Inflorescences 1-5 per axil, usually $1-3$, most frequently 1 or 2 ; peduncles erect, $5-7 \mathrm{~cm}$ long in flower, 8-13 $\mathrm{cm}$ long and pendent in fruit; spathe ca. $14 \mathrm{~cm}$ at anthesis; spathe tube narrowly ellipsoid, 4.5-6 cm long, 2-2.5 cm diam., pale green outside, red inside to near the apex; spathe blade oblong-elliptic to oblong, white on both sides, short cuspidate and weakly cucullate at the apex, $8-9 \mathrm{~cm}$ long, ca. $3.5 \mathrm{~cm}$ diam. (to $5 \mathrm{~cm}$ wide when flattened); pistillate portion of the spadix 1.9-2.5 cm long (fresh) (1$1.8 \mathrm{~cm}$ long dry), 7-13 mm diam., pale yellowish white, the flowers irregularly 4-sided, the stigma sessile, cup shaped; staminate portion of the spadix $6-10 \mathrm{~cm}$ long, 1-1.5 cm diam., clavate, gradually attenuate toward the sterile flowers, the fertile staminate flowers 4-staminate, the anthers partially or completely fused, the synandrium truncate or slightly rounded at the apex, the staminate sterile flowers slightly longer than the adjacent fertile staminate flowers and much longer than the pistillate flowers, 4-6-sided to ellipsoid or subglobose; the spathe tube becomes rolled backward along its lateral margins and the fleshy white spadix is prominently displayed against the bright red interior of the spathe tube. Infructescences oblong-elliptic, green tinged with purple, becoming violet purple on the 

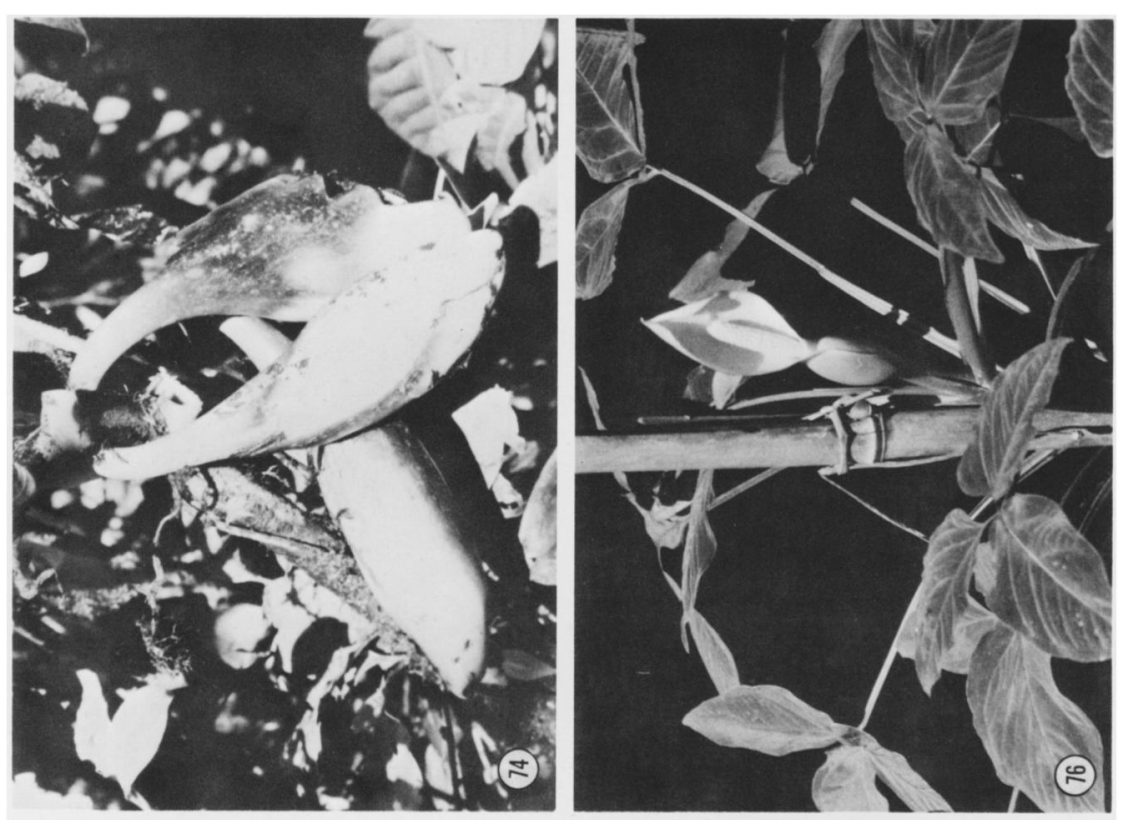

突!

के ठ

ते

ड के

نे

క్

इक

i.

节㺼

!

흘

음

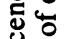

要

已气

$\pm \sum_{\infty} \rightarrow$

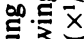

호은

동

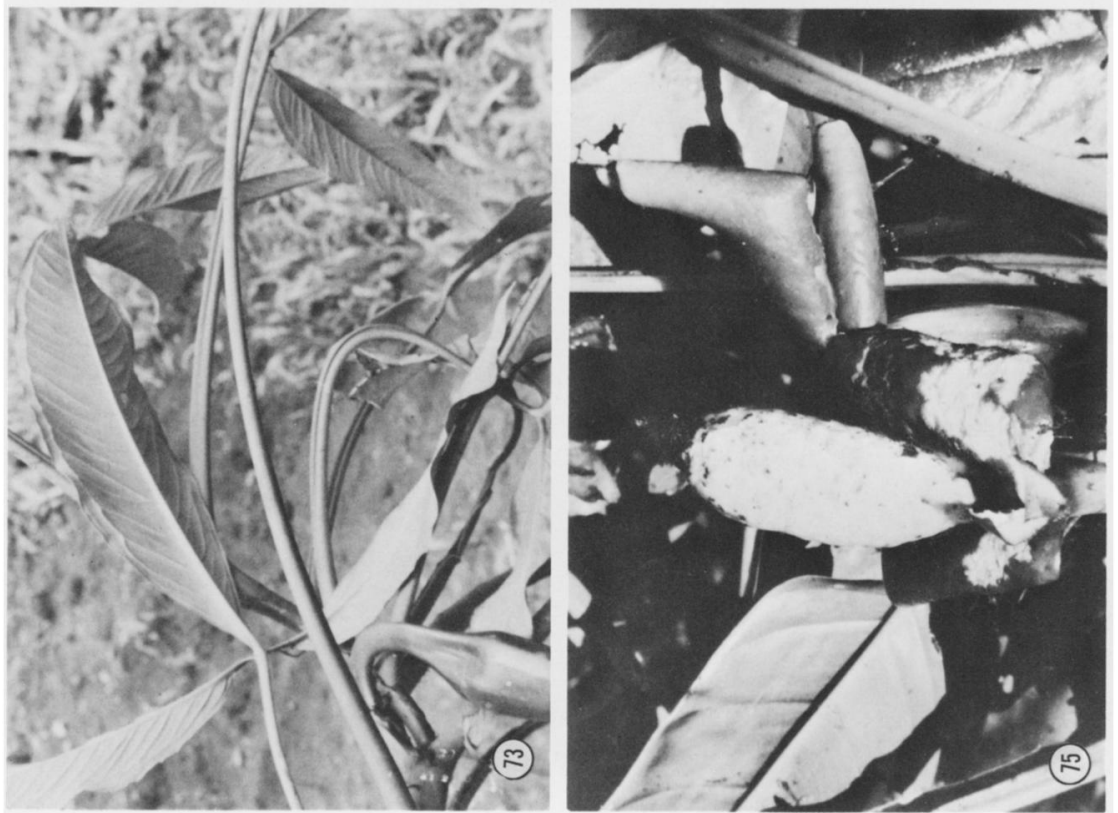

उ赵象

范口

동

늑로잉

호을

柁远

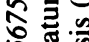

$\Re$ है

छे

U⿺辶寸

हี :

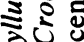

है

혼을

촐

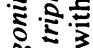

究山䒕

น

लं।

1 定吾

$\hat{x} \bar{x}: \because$

ल

\&

แ్ํㅀ

可 ญ

位的

ف 
outside, the inner surface bright red; spadix oblong-ellipsoid, 6-8 cm long, 3.5$4 \mathrm{~cm}$ diam.; mesocarp white, fleshy, sweet; seeds black, irregularly ovoid to ellipsoid, 5-8 cm long, 4-6 cm wide. Figs. 68, 73-75.

DisTRIBUTION: Syngonium triphyllum ranges from the northern Atlantic coast of Honduras to central Panama. It also occurs on the Pacific slope at Palmar Norte in Puntarenas Province, Costa Rica, and on the Burica Peninsula between Panama and Costa Rica. It no doubt occurs as well on the Osa Peninsula in Costa Rica. It is probably restricted to premontane wet forest and tropical wet forest below $1000 \mathrm{~m}$.

Birdsey (1955) reported the species to be in virgin areas in Honduras but from disturbed areas in Costa Rica. I have always found it growing in virgin forest or in disturbed remnant virgin forest but never in a weedy situation.

The species may be recognized by having leaves with numerous conspicuously sunken veins, by drying almost black, and by having juvenile blades with small, more or less spatulate lateral lobes that are directed laterally. Other distinguishing characters include the cucullate spathe blade, the sessile cup-shaped stigma, and the petiole cross-sectional shape which has an acute medial rib and conspicuously raised lateral margins.

According to Birdsey (1955) the pollen of $S$. triphyllum is unique for Syngonium with the "surface almost completely covered with more or less orbicular knobs.'"

Inflorescences have been found from February through May and in October and November. Immature fruits are known from March to October with nearly mature fruits in May, June, and July.

Costa Rica: alajuela: Vicinity of Bijauga, Burger \& Baker 9850 (F), Croat 36268, 36484 (MO), Utley \& Utley 3906 (DUKE); NE of Villa Quesada, Croat 46972 (MO). CARTAGo: NE of Turrialba, Croat 43376 (MO). HEREdiA: Near Río Puerto Viejo, Burger \& Stolze 5864 (F), Croat 35675 (MO). LIMón: Vicinity of Bribri, Croat 43227, 43219 (MO); Siguirres, Baker \& Burger 188 (F); Near Tortuguero, Davidson 6946 (MO). PUnTarenas: Above Palmar Norte, Allen 5929 (F), Croat 35111, 35136 (MO). SAN JOSÉ: SW of San Isidro, Croat 35258, 35262 (MO).

Honduras: AtLantida: Lancetilla Valley, Near Tela, Birdsey 319 (UC, not seen).

Nicaragua: zelaya: SW of Colonia Naciones Unidas, Stevens 4986 (MO); S of Colonia Yolania, Stevens 4853 (MO).

Panama: Chiriquí: W of Puerto Armuelles, Croat 22008, 35080 (MO). coclé: Cerro Pilón, Liesner 778 (MO); Road to Coclecito, Croat 49228 (MO); La Mesa, Croat 25358, 25362, 37341 (MO). COLón: Vicinity of Guásimo, Croat 9939 (MO, SCZ). Río Guanche, Croat 36999 (F, MO). VERAGUAS: NW of Santa Fe, Croat 23118, 25643 (MO); Between Escuela Agrícola Alto Piedra and Calovebora, Croat 23235 (F), 27572, 34142 (MO).

32. Syngonium wendlandii Schott, Oesterr. Bot. Z. 8:178. 1858. TYPE: Costa Rica, San José, Santa Ana (ca. $10 \mathrm{~km} \mathrm{~W}$ of San José), Wendland s.n. (B, now destroyed; Schott drawing 3243 seen).

Juvenile plants with stems not glaucous; internodes at first short, $2-4 \mathrm{~cm}$ long, becoming longer, to $10 \mathrm{~cm}$ long; petioles sheathed $1 / 3-3 / 4$ their length (usually less than $1 / 2$ ); blades cordate, to $10 \mathrm{~cm}$ long, the anterior lobe ovate, acuminate, the posterior lobes semiorbicular; intermediate blades sagittate to hastate, the posterior lobes triangular, the upper surface velvety green, the major veins streaked with silver gray. Adult plants with stems green, not glaucous; internodes $1-5 \mathrm{~cm}$ long, 0.5-2.5 cm diam.; petioles $10-32 \mathrm{~cm}$ long, sheathed $1 /{ }_{2}-4 / 5$ their length, the 
free portion above the sheath acutely angled medially, the lateral margins acute; blades trisect, dark velvety green, sometimes with a streak of silver gray, the epidermis of conspicuous papillate cells; median leaflet $8-20 \mathrm{~cm}$ long, $2-8 \mathrm{~cm}$ wide, elliptic to oblong-elliptic, acuminate at the apex, acute to cuneate at the base; primary lateral veins $6-10$ pairs; lateral leaflets $7-15 \mathrm{~cm}$ long, 3-6 cm wide, oblong-elliptic to narrowly ovate, acute to acuminate at the apex, inequilateral, the inner margin acute, the outer margin rounded to auriculate, the auricles sometimes pinched off, oblong-elliptic, to $3 \mathrm{~cm}$ long. Inflorescences 1-3 per axil; peduncles $8-10 \mathrm{~cm}$ long, obtusely triangular; spathe tube $5-6 \mathrm{~cm}$ long, $2-2.5 \mathrm{~cm}$ diam., narrowly ovoid, pale green outside, red inside; spathe blade elliptic, 8$10.5 \mathrm{~cm}$ long, acuminate at the apex, pale yellowish green outside, white inside; spadix weakly sigmoid, curved outward in the pistillate and lower part of the sterile staminate portions, then turned inward again in the upper part of the sterile staminate section; pistillate portion of the spadix $1.5-2 \mathrm{~cm}$ long, to $1 \mathrm{~cm}$ diam., the flowers irregularly 6-sided, the stigma orbicular or 2-lobed; staminate portion of the spadix white, $5.5-8.5 \mathrm{~cm}$ long, more or less cylindroid and markedly tapered onto the sterile staminate part of the spadix; the staminate flowers 2-4androus (usually 4), the synandrium crenate near the apex, the area of fusion of the stamens somewhat visible; the sterile staminate flowers irregular, larger than the fertile flowers and well-spaced for the genus. Infructescences pendent, oblong; syncarp oblong, $2.6-5.8 \mathrm{~cm}$ long, $1.4-2.4 \mathrm{~cm}$ wide, white to brown (fide Birdsey, 1955); seeds not seen. Figs. 76-78.

Distribution: The species is endemic to Costa Rica, occurring at about 1000 $m$ elevation in premontane moist forest in the Meseta Central, west of the city of San José.

It can be recognized by its trisect leaves with a densely papillate upper epidermis and by its inflorescence with a frequently sigmoid spadix and widely spaced sterile staminate flowers.

The species is most easily confused with $S$. hoffmannii, a species with similar leaves that occurs at higher elevations $(1500-1800 \mathrm{~m})$ on the slopes surrounding the Meseta Central. The latter species is distinguished by the lack of conspicuous papillate leaf epidermis and by having a stouter spadix that is scarcely constricted at the base with the sterile staminate flowers closely compacted. Under magnification, the papillae on the upper surface of the leaf blades of $S$. wendlandii appear as minute reddish-brown glands (on dried specimens).

Birdsey (1955) is of the opinion that the leaves of the type specimens that have been photographed in Berlin were switched, with each species having its proper inflorescence but the leaves of the opposite species. (See photo FM 12299 for $S$. wendlandii and FM 12294 for $S$. hoffmannii.) The actual specimens of both species are no longer extant having been destroyed both at Berlin and Vienna; nor is the type of $S$. wendlandii among the specimens of the Wendland collection now housed at Göttingen.

I am not necessarily in agreement with Birdsey that the Berlin type photos are mixed. While the leaves of $S$. wendlandii are easily distinguishable by the conspicuous papillae on the upper leaf surface, these cannot be distinguished from the photos. The two species have leaves that are otherwise rather similar. In my opinion the leaf on the Berlin photo (FM 12294) of S. hoffmannii matches 

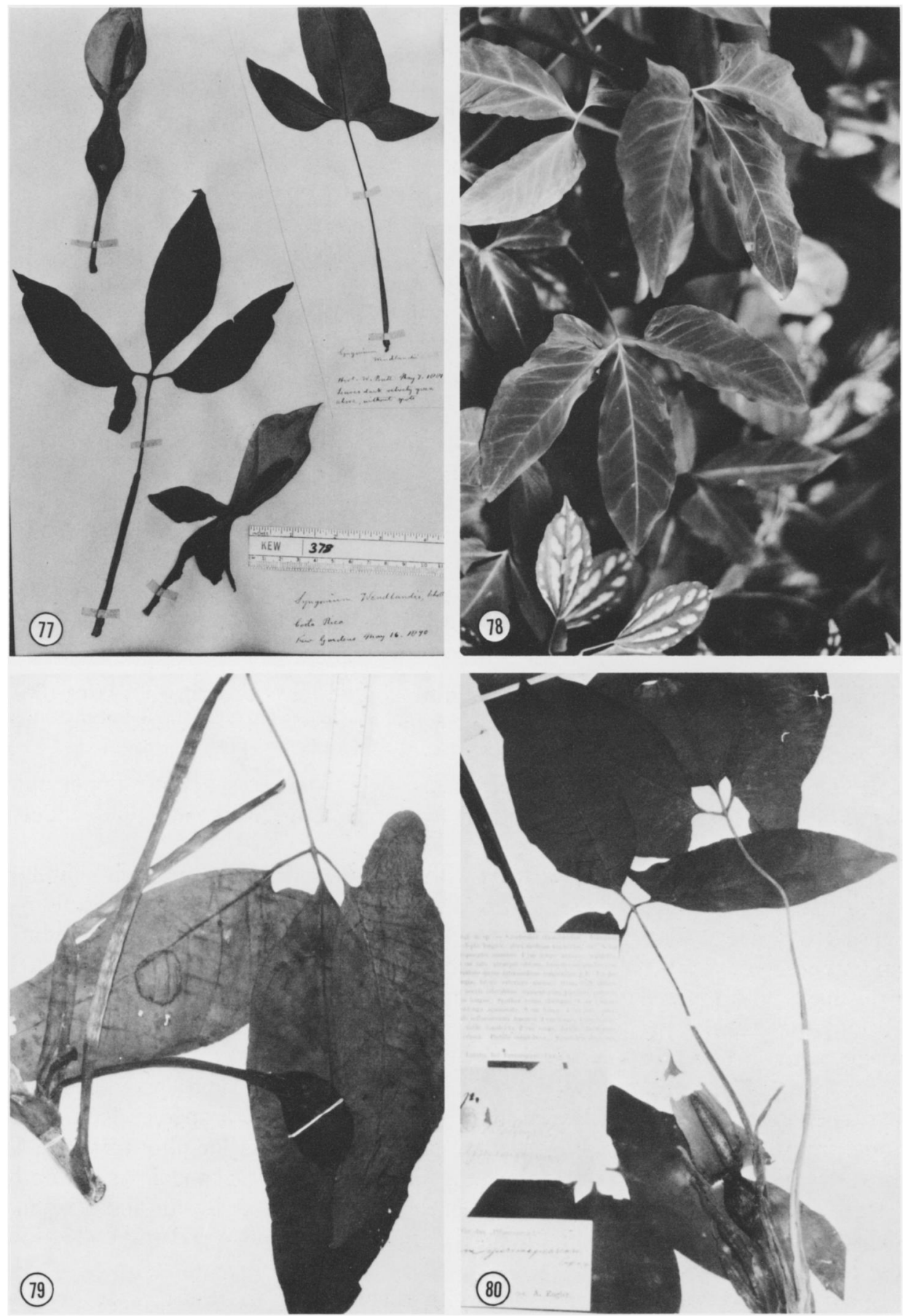

FIGURES 77-80.-77. Syngonium wendlandii (cult. at Kew); adult blade with inflorescences.78. S. wendlandii, growing at Foster Gardens; adult blades $\left(\times^{1 / 5}\right) .-79$. S. yurimaguense, Prance et al. 6278; adult plant with infructescence.-80. S. yurimaguense, Ule s.n.; adult plant with inflorescence $\left(x^{1 / 6}\right)$. 
closely the original Schott drawing (Schott Aroideae 3212) prepared at Vienna under the direction of Schott from the original (probably living) material collected by Wendland. It is possible, on the other hand, that the Berlin type photo of $S$. wendlandii (FM 12299) represents a mixed collection with perhaps a leaf of $S$. hoffmannii since this leaf does not so closely match the original Schott painting in Vienna (Schott Aroideae 3243).

Costa Rica: alajuela: Vicinity of Capulin, Standley 40120 (US). SAN José: Río María Aguillar, Standley 38990 (US); Wendland Photo \#12299 (US).

33. Syngonium yurimaguense Engler, Bot. Jahrb. Syst. 38:141. 1905. TYPE: Peru, Loreto, Yurimaguas, Ule 9237 (B, holotype; $\mathrm{K}$, isotype).

Hemiepiphytic vine; stem $1-1.5 \mathrm{~cm}$ diam., the epidermis becoming brown, flaking; petioles slender, sheathed to upper $2 / 3$, about as long as or to 3 times longer than the blade, $24-36 \mathrm{~cm}$ long, the sheath briefly free-ending and acute, the unsheathed portion acute adaxially; blades thin, trisect, the leaflets conspicuously free; median leaflet ovate-elliptic to oblong-elliptic, bluntly acute to gradually acuminate at the apex, obtuse to acute and attenuate at the base, $11-23 \mathrm{~cm}$ long, 4.5-9 $\mathrm{cm}$ wide; primary lateral veins 4-7 pairs, at least part of them departing the midrib at $90^{\circ}$ angle, then arcuate or almost straight to the collective vein; tertiary veins distinct; primary collective vein distinct, $2-6 \mathrm{~mm}$ from the margin, generally more or less straight; lateral leaflets generally somewhat narrower, acuminate or narrowly acute on the inner margin at the base, hastate lobed on the outer margin, the auricles $2-5 \mathrm{~cm}$ long, acute to narrowly rounded at the apex. Inflorescences 1-2 per axil, the prophylls slender; peduncles ca. $6.5 \mathrm{~cm}$ long at anthesis, less than $3 \mathrm{~mm}$ diam. (dried); spathe 9-10 $\mathrm{cm}$ long; spathe tube oblong-elliptic, $3-3.5 \mathrm{~cm}$ long, ca. $1.5 \mathrm{~cm}$ diam., probably green; spathe blade oblong-elliptic, acuminate at the apex, white (fide Engler, 1877), pistillate portion of the spadix $2 \mathrm{~cm}$ long, $1 \mathrm{~cm}$ diam. (dried), the pistils depressed-globose; staminate portion of the spadix clavate, ca. $5 \mathrm{~cm}$ long, $7 \mathrm{~mm}$ diam. (dried), the sterile flowers irregular, 1-1.5 mm diam., broadest in the direction of the axis, the fertile flowers irregularly 4-5-sided, completely fused into a synandrium with no sign of fusion, the apex truncate, margin irregularly scalloped. Infructescences creamy yellow, subglobose, $5.5 \mathrm{~cm}$ long, $4.5 \mathrm{~cm}$ diam.; peduncle to $2 \mathrm{~cm}$ long; seeds black, 4-5 mm long. Figs. 79, 80.

Distribution: Syngonium yurimaguense is known from Brazil, Ecuador, Peru, and Bolivia at elevations of 50 to $700 \mathrm{~m}$.

It is closely related to $S$. atrovirens from western Venezuela but differs in having the spathe tube conspicuously constricted below the blade. Syngonium yurimaguense shares with $S$. atrovirens moderately thin leaves which have the medial lobe bearing veins which depart the midrib at almost a $90^{\circ}$ angle. In other species of Syngonium the primary lateral veins depart the midrib at an acute angle.

Bolivia: Pando: Cobija, Río Acre, Ule 9237 (K).

BraziL: No other location, Burchell 9859 (K). Amazonas: N of Ribeirão, Prance et al. 6278 (INPA, NY, US). 
ECUADOR: NAPO: N of Puyo, Croat 49660 (MO).

PERU: cuzco: Paucartambo, Vargas 13426 (US). LORETo: Yurimaguas, Ule s.n. (B). MADRE DE DIos: Province of Manú, Terborgh $6739 B(\mathrm{~F})$.

\section{EXCLUDED SPECIES}

Syngonium connatum Gleason, Bull. Torrey Bot. Club 56:13. 1929. TYPE: Guyana, Rupununi River, Jenman $5756(\mathrm{~K}$, holotype $)=$ Philodendron hylaeae Bunting.

Syngonium reticulatum Engler, Bot. Jahrb. Syst. 37:140. 1905. TYPE: Ecuador, San Nicolaus, Sodiro 39 (B, holotype) = Xanthosoma daguense Engler.

Syngonium rothschuhianum Engler \& Krause, Pflanzenr. IV. 23E (Heft 71):124. 1920. TYPE: Nicaragua, Matagalpa, $1000 \mathrm{~m}$, Rothschuh 229 (B, holotype) $=$ Philodendron anisotomum Schott.

\section{DoubTful TAXA}

Syngonium podophyllum Schott var. multisectum Engler, Pflanzenr. IV. 23E (Heft 71):129. 1920. TYPE: Based on Duss 519 collected in a botanical garden in Martinique, previously cultivated in Buitenzorg, Java (not seen).

Syngonium sp. Killip 5835, consisting of part of three leaflets and lacking a petiole or any connection between the leaflets, is unusual and may represent a new species. The collection was made at La Cumbre in Colombia in the Department of Valle.

\section{Literature Cited}

BeEvers, H. 1950. Experiments on respiration of aroid species. Amer. J. Bot. 37:675-676.

BirdSEY, M. 1955. The morphology and taxonomy of the genus Syngonium (Araceae). Ph.D. dissertation, Univ. of California, Berkeley. $382 \mathrm{pp}$.

Bunting, G. 1966. New syngoniums in cultivation (Araceae). Baileya 14:15-21.

CROAT, T. B. 1978. Flora of Barro Colorado Island. Stanford Press, Stanford, California.

\& G. S. Bunting. 1979. Standardization of Anthurium descriptions. Aroideana 2:15-25.

DilchER, D. L. 1974. Approaches to the identification of angiosperm leaf remains. Bot. Rev. 40:1157.

Dodson, C. \& A. H. Gentry. 1978. Flora of the Río Palenque Science Center. Selbyana 4:1-628.

ENGLER, A. 1877. Vergleichende Untersuchungen über die morphologischen Verhaltnisse der Araceae. II Theil. Über Blattstellung und Sprossberhaltnisse der Araceae. Nova Acta Acad. Caes. Leop.-Carol. German. Nat. Cur. 39:159-232.

IV K. KRAUSE. 1920. Araceae: pars generalis et index familie generalis. Das Pflanzenreich IV. 23A (Heft 74):1-71.

HATCH, M. D. \& A. MillaRD. 1957. Respiration of the spadix from the aroid Zantedeshia aethiopica Spreng. Austral. J. Biol. Sci. 10:310-319.

Hess, C. M. \& B. J. D. Meeuse. 1968a. Factors contributing to the respiratory flare-up in the appendix of Sauromatum I. Proc. Kon. Ned. Akad. Wetensch., Ser. C., Biol. Med. Sci. 71:443455.

- \& $1968 \mathrm{~b}$. Factors contributing to the respiratory flare-up in the appendix of Sauromatum II. Proc. Kon. Ned. Akad. Wetensch., Ser. C., Biol. Med. Sci. 71:456-471.

HotTA, M. 1971. Study of the family Araceae, general remarks. Jap. J. Bot. 20:269-310.

Hutchinson, J. 1932. The Families of Flowering Plants. Vol. 2. Monocotyledons. Clarenden Press, Oxford.

James, W. O. \& H. BeEvers. 1950. The respiration of Arum spadix, a rapid respiration resistant to cyanide. New Phytol. 49:353-374. 
Jones, G. E. 1957. Chromosome numbers and phylogenetic relationships in the Araceae. Ph.D. dissertation, Univ. of Virginia, Charlottesville. $182 \mathrm{pp}$.

Knutson, R. M. 1972. Temperature changes in heat producing plants. Bull. Calif. Acad. Sci. 71:5455. $186: 746-747$.

LARSEN, K. 1969. Cytology of vascular plants III, A study of Thai aroids, Studies in the Flora of Thailand. Dansk. Bot. Ark. 27:39-59.

Madison, M. 1977. A revision of Monstera (Araceae). Contr. Gray Herb. 207:3-100.

. 1978. The genera of Araceae in the northern Andes. Aroideana 1:31-53.

Marchant, C. J. 1970. Chromosome variation in Araceae I: Pothoeae to Stylochitoneae. Kew Bull. 24:315-322.

․ 1971a. Chromosome variation in Araceae II. Richardieae to Colocasieae. Kew Bull. 25:4756.

- 1971b. Chromosome variation in Araceae III. Philodendreae to Pythonieae. Kew Bull. 25:323-329.

1972. Chromosome variation in Araceae IV. Areae. Kew Bull. 26:395-404.

NAgY, K. A., D. K. Odell \& R. S. Seymour. 1972. Temperature regulation by the inflorescence of Philodendron. Science 178:1195-1197.

PIJL, L. VAN DER 1933. Welriekende vliegenbloemen bij Alocasia pubera. Trop. Natuur 22:210-214.

Poeprig, E. F. \& S. L. Endlicher. 1845. Nov. Gen. et Sp. III. 7:89.

Pfitzer, P. 1957. Chromosomenzahlen von Araceen. Chromosoma 8:436-446.

Sharma, A. K. 1970. Annual Report, 1967-1968. Res. Bull. Univ. Calcutta (Cytogenetics Lab) 2:150.

Sснотт, H. W. 1829. Wiener Zeitschrift fur Kunst, Theater und mode 3. 780.

1856. Synopsis Aroidearum. Wien.

1858. Genera Aroidearum. Wien.

1860. Prodromus Systematis Aroidearum. Wien.

Sheridan, W. F. 1960. The occurrence of a temperature fluctuation in the spadix of Philodendron selloum. Master's thesis, Univ. of Florida, Gainsville.

Smith, B. N. \& B. J. D. Meeuse. 1966. Production of volatile amines and skatole at anthesis in some arum lily species. Pl. Physiol. (Lancaster) 41:343-347.

Solereder, H. \& F. J. Meyer. 1928. Systematische Anatomie der Monokotyledonen 3:1-175.

Strong, D. R. \& T. S. RAY. 1975. Host tree location behavior of a tropical vine (Monstera gigantea) by skototropism. Science 190:804-806.

Van Tieghem, P. 1867. Recherches sur la structure des Aroidees. Ann. Sci. Nat. Bot. sér 5, 6:72210 .

INDEX

Synonyms are in italics; illustration page numbers are boldface.

Acontias 566, 567

Alocasia 566, 567, 574

A. pubera 576

Alocasinae 566

Amorphophallus 575

Anchomanes 566

Anubiadinae 567

Anubias 567

Aphyllarum 567

Ariopsideae 567

Ariopsis 566, 567, 574

Arisaemum 575

Arum 565, 575

A. auritum 579, 630

Biarum 575

Caladiinae 566, 567

Caladiopsis 567

Caladium 565-567, 574

C. auritum 609

Chlorospatha 567

Colocasia 566, 567, 574

Colocasiinae 566, 567

\author{
Colocasioideae 572, 573 \\ Cyclocephala 575 \\ Dieffenbachia 575 \\ Efilamentae 566 \\ Filamentae 566 \\ Gonatanthus 566, 567 \\ Gyminogoneae 566 \\ Hapaline 566, 567 \\ Hapalininae 567 \\ Leucocasia 567 \\ Monstera 565, 575, 577, 578 \\ Nephtytis triphylla 606 \\ Pachyzeugmaticae 566 \\ Peltandra 566, 567 \\ Peltandrinae 566 \\ Peristatogoneae 566 \\ Philodendrinae 566 \\ Philodendroidae 566 \\ Philodendron 565, 575 \\ P. anisotomum 649 \\ $P$. armigerum 585 \\ $P$. hastiferum 591, 595
}


P. hylaeae 649

P. radiatum 572, 604

Porphyrospatha 565, 567, 572, 579, 616

$P$. crassifolia 591

P. hoffmannii 616

P. schottiana 602

Pothos auritas 630

Problematicae 566

Remusatia 566, 567, 574

Sauromatum 575

Schizocasia 567

Steudnera 567

Stenozeugmaticae 566

Stylochiton 566

Symplocarpus 575

Syngonieae 566, 567

Syngonium 566, 567

Sect. Cordatum 572, 578, 579, 588

Sect. Oblongatum 570, 572, 579, 585

Sect. Pinnatilobum 572, 579, 604

Sect. Syngonium 571, 572, 578, 579, 604

S. affine 630

S. albolineatum 606

S. amazonicum 630

S. angustatum 565, 569, 573-575, 577, 578, 605-607, 614, 619, 631

S. apurense 608

S. armigerum 579, 585, 586

S. atrovirens $608,609,611,648$

S. auritum 565, 574, 604, 609, 611, 633

var. neglectum 626, 628

S. chiapense $569,574,579,588,589,590,601$

S. chocoanum 589, 590, 591, 597, 598

S. connatum 649

S. crassifolium 569, 578, 591, 594, 598, 600, 601, 604

S. decipiens 630

S. dodsonianum 589, 592

S. donnell-smithii 637

S. erythrophyllum 569, 610, 612, 617, 619

S. foreroanum $\mathbf{5 8 9}, 594$

S.. gentryanum $571,578,612,613,617$

S. glaucopetiolatum 578, 613, 615, 617, 619

S. gracilis (S. gracile) 606, 630

S. harlingianum $615-617$

S. hastiferum 593, 595, 596, 597, 600, 603

S. hastifolium $566,578,579,593,597$

S. hoffmannii $565,571,574,616,618,619$, $621,623,625,646$

S. laterinervium 566, 577, 578, 596, 620, 621

\section{S. llamasii 588}

S. llanoense $578,579,585, \mathbf{5 8 6}-588,601$

S. macrophyllum 566, 569, 574, 575, 577, 578, $590,621,622,623,625,631,632$

S. mauroanum $576,578,615,623,624,626$, 629

S. meridense 591, 593, 595, 597, 598, 599

S. morelosense 626

S. neglectum 565, 574, 626, 627, 629, 631, 632, 639

S. occidentale $577,578,627$

S. oduberi 587, 588, 596

S. oerstedianum 606

S. peliocladum 633, 636

S. plumieri 609

S. podophyllum 565, 571-574, 578, 579, 597, $606,628-631,633$

var. multisectum 630, 649

var. peliocladum 569, 578, 636-638, 641

var. podophyllum 569, 632, 638, 641

S. poeppigii 630,633

S. reticulatum 579, 649

S. riedelianum 630

S. rothschuhianum 649

S. ruizii 630

S. sagittatum 569, 577, 578, 597, 599, 600, 604,607

S. salvadorense $565,574,637,638,639$

S. schottianum $565,567,569,577-579,588$, $597,600,602,603,604,607$

S. sparreorum $578,613,639-641$

S. standleyanum 626,640

S. steyermarkii 566, 572, 578, 579, 604, 607, 614

S. ternatum 630

S. triphyllum 566, 571, 574, 575, 576, 638, $642,644,645$

S. vellozianum $630,631,633$ var. oblongisectum 633

S. wendlandii $565,571,574,576,620,644$, $645,646,647$

S. willdenowii 630

S. yurimaguense $609,647,648$

S. xanthophylum 630, 633

Symplocarpus 575

Typhonodorum 566

Xanthosoma 565-567, 573-575, 594

$X$. daguense 649

$X$. gracile 630

Zamioculcas 566, 567 